San Jose State University

SJSU ScholarWorks

Mineta Transportation Institute Publications

$11-2021$

\title{
Safeguarding Equity in Off-Site Vehicle Miles Traveled (VMT) Mitigation in California
}

Serena E. Alexander

San Jose State University, serena.alexander@sjsu.edu

Mariela Alfonzo

Mineta Transportation Institute

Kevin Lee

San Jose State University

Follow this and additional works at: https://scholarworks.sjsu.edu/mti_publications

Part of the Social Welfare Commons, and the Transportation Commons

\section{Recommended Citation}

Serena E. Alexander, Mariela Alfonzo, and Kevin Lee. "Safeguarding Equity in Off-Site Vehicle Miles Traveled (VMT) Mitigation in California" Mineta Transportation Institute Publications (2021).

https://doi.org/10.31979/mti.2021.2027

This Report is brought to you for free and open access by SJSU ScholarWorks. It has been accepted for inclusion in Mineta Transportation Institute Publications by an authorized administrator of SJSU ScholarWorks. For more information, please contact scholarworks@sjsu.edu. 


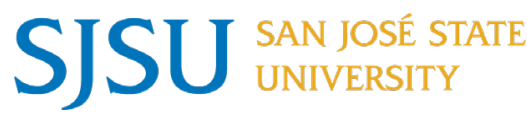

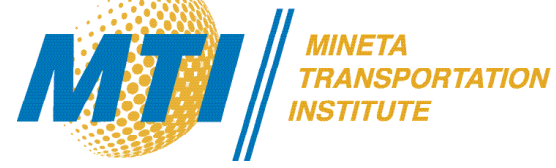

Safeguarding Equity in Off-Site Vehicle Miles Traveled (VMT)

Mitigation in California

Serena E. Alexander, $\mathrm{PhD}$

Mariela Alfonzo, $\mathrm{PhD}$

Kevin Lee
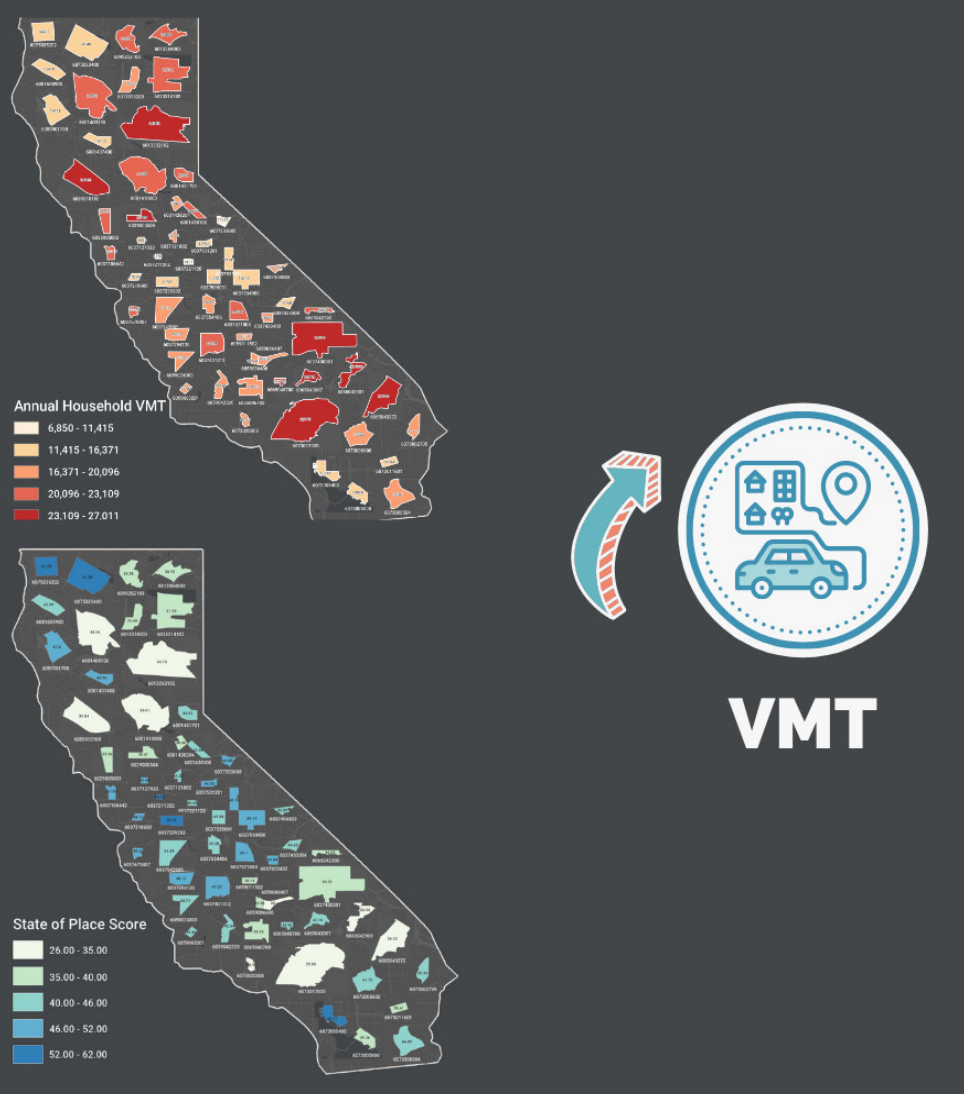
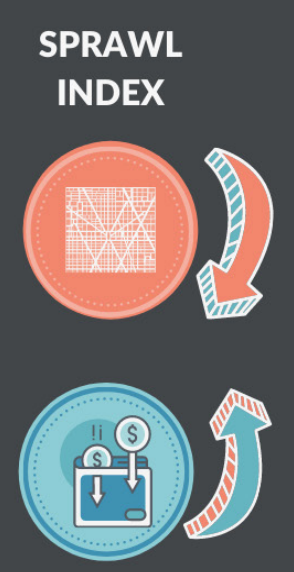

HOUSEHOLD

INCOME

\section{STATE OF \\ PLACE}
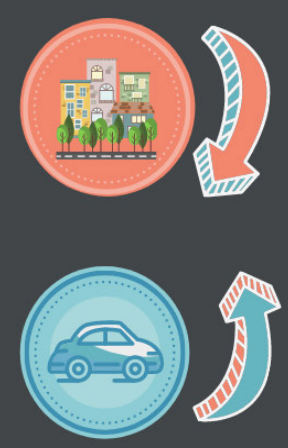

VEHICLE

ACCESS
TRANSIT

ACCESS
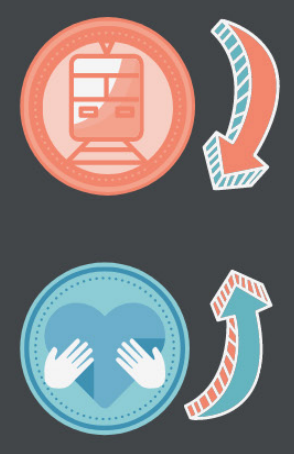

CAL-ENVIRO SCREEN

California State University
Transportation Consortium

SJSU 


\section{Mineta Transportation Institute}

Founded in 1991, the Mineta Transportation Institute (MTI), an organized research and training unit in partnership with the Lucas College and Graduate School of Business at San José State University (SJSU), increases mobility for all by improving the safety, efficiency, accessibility, and convenience of our nation's transportation system. Through research, education, workforce development, and technology transfer, we help create a connected world. MTI leads the Mineta Consortium for Transportation Mobility (MCTM) funded by the U.S. Department of Transportation and the California State University Transportation Consortium (CSUTC) funded by the State of California through Senate Bill 1. MTI focuses on three primary responsibilities:

\section{Research}

MTI conducts multi-disciplinary research focused on surface transportation that contributes to effective decision making. Research areas include: active transportation; planning and policy; security and counterterrorism; sustainable transportation and land use; transit and passenger rail; transportation engineering; transportation finance; transportation technology; and workforce and labor. MTI research publications undergo expert peer review to ensure the quality of the research.

\section{Education and Workforce}

To ensure the efficient movement of people and products, we must prepare a new cohort of transportation professionals who are ready to lead a more diverse, inclusive, and equitable transportation industry. To help achieve this, MTI sponsors a suite of workforce development and education opportunities. The Institute supports educational programs offered by the Lucas Graduate School of Business: a
Master of Science in Transportation Management, plus graduate certificates that include High-Speed and Intercity Rail Management and Transportation Security Management. These flexible programs offer live online classes so that working transportation professionals can pursue an advanced degree regardless of their location.

\section{Information and Technology Transfer}

MTI utilizes a diverse array of dissemination methods and media to ensure research results reach those responsible for managing change. These methods include publication, seminars, workshops, websites, social media, webinars, and other technology transfer mechanisms. Additionally, MTI promotes the availability of completed research to professional organizations and works to integrate the research findings into the graduate education program. MTI's extensive collection of transportation-related publications is integrated into San José State University's world-class Martin Luther King, Jr. Library.

\section{Disclaimer}

The contents of this report reflect the views of the authors, who are responsible for the facts and accuracy of the information presented herein. This document is disseminated in the interest of information exchange. MTI's research is funded, partially or entirely, by grants from the California Department of Transportation, the California State University Office of the Chancellor, the U.S. Department of Homeland Security, and the U.S. Department of Transportation, who assume no liability for the contents or use thereof. This report does not constitute a standard specification, design standard, or regulation. 
Report 21-30

\section{Safeguarding Equity in Off-Site Vehicle Miles Traveled (VMT) Mitigation in California}

Serena E. Alexander, PhD

Mariela Alfonzo, $\mathrm{PhD}$

Kevin Lee

November 2021

A publication of the

Mineta Transportation Institute

Created by Congress in 1991

College of Business

San José State University

San José, CA 95192-0219 


\section{TECHNICAL REPORT \\ DOCUMENTATION PAGE}

\begin{tabular}{|c|c|}
\hline 2. Government Accession No. & 3. Recipient's Catalog No. \\
\hline $\begin{array}{l}\text { 4. Title and Subtitle } \\
\text { Safeguarding Equity in Off-Site Vehicle Miles Traveled (VMT) Mitigation in } \\
\text { California }\end{array}$ & $\begin{array}{l}\text { 5. Report Date } \\
\text { November } 2021 \\
\text { 6. Performing Organization Code }\end{array}$ \\
\hline $\begin{array}{l}\text { 7. Authors } \\
\text { Serena E. Alexander, PhD: 0000-0001-8359-5289 } \\
\text { Mariela Alfonzo, PhD } \\
\text { Kevin Lee }\end{array}$ & $\begin{array}{l}\text { 8. Performing Organization } \\
\text { Report } \\
\text { CA-MTI-2027 }\end{array}$ \\
\hline $\begin{array}{l}\text { 9. Performing Organization Name and Address } \\
\text { Mineta Transportation Institute } \\
\text { College of Business } \\
\text { San José State University } \\
\text { San José, CA 95192-0219 }\end{array}$ & \begin{tabular}{|l|} 
10. Work Unit No. \\
$\begin{array}{c}\text { 11. Contract or Grant No. } \\
\text { ZSB12017-SJAUX }\end{array}$
\end{tabular} \\
\hline $\begin{array}{l}\text { 12. Sponsoring Agency Name and Address } \\
\text { State of California SB1 2017/2018 } \\
\text { Trustees of the California StateUniversity } \\
\text { Sponsored Programs Administration } \\
\text { 401 Golden Shore, } 5^{\text {th }} \\
\text { Long Beach, CA } 90802\end{array}$ & $\begin{array}{l}\text { 13. Type of Report and Period } \\
\text { Covered } \\
\text { 14. Sponsoring Agency Code }\end{array}$ \\
\hline
\end{tabular}

15. Supplemental Notes

16. Abstract

Historically, the State of California assessed the environmental impacts of proposed developments based on how it was projected to affect an area's level of service (LOS). However, as LOS focused on traffic delays, many agencies simply widened roads, which was an ineffective way to reduce greenhouse gas emissions (GHGs). With the passage of Senate Bill (SB)743 in 2013, LOS was replaced by Vehicle Miles Traveled (VMT) as a more appropriate metric by which to gauge the environmental impacts of proposed development. Additionally, SB 743 presented an opportunity for off-site VMT mitigation strategies through banking and exchanges- allowing multiple development projects to fund a variety of strategies to reduce VMT elsewhere in the city or region. While the shift from LOS to VMT has generally been lauded, concerns remain about how to apply SB 743 effectively and equitably. This study aimed to: 1) understand how local governments are addressing this shift toward VMT while ensuring equity, including its approaches to off-site VMT mitigation; and 2) evaluate the various built environment factors that impact VMT, which should be considered by local governments, using both qualitative and quantitative research designs. The study posited that both micro and macro level aspects of the built environment needed to be considered when evaluating the impacts of proposed development on VMT, not only to ensure higher accuracy VMT models, but also because of the potential equity implications of off-site mitigation measures. Using multiple linear regression, the study shows that macroscale built environment features such as land use, density, housing, and employment access have a statistically significant impact on reducing VMT (35\%), along with transit access (15\%), microscale features such as sidewalks, benches, and trees (13\%), and income (6\%). More notably, a four-way interaction was detected, indicating that VMT is dependent on the combination of macro and micro level built environment features, public transit access, and income. Additionally, qualitative interviews indicate that transportation practitioners deal with three types of challenges in the transition to VMT impact mitigation: the lack of reliable, standardized VMT measure and evaluation tools; the lack of a strong legal foundation for VMT as a component of the California Environmental Quality Act (CEQA); and the challenge of distributing off-site VMT mitigation equitably. Overall, findings support a nuanced, multi-factor understanding of the context in which new developments are being proposed, both in terms of modeling VMT, but also when considering whether offsite mitigation would be appropriate. The results of this study can help California ensure equitable VMT mitigation that better aligns with the state's climate goals. 


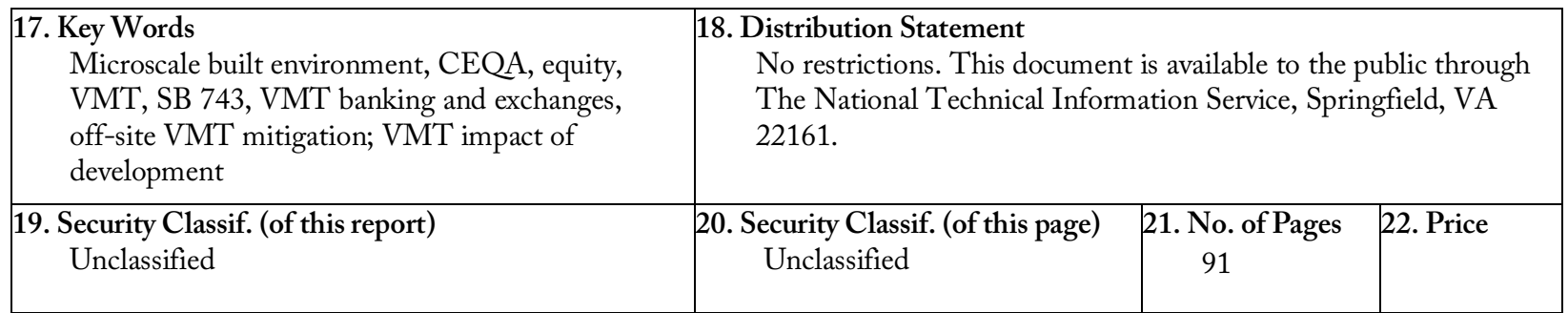

Form DOT F 1700.7 (8-72) 
Copyright (C) 2021

\section{by Mineta Transportation Institute}

All rights reserved.

DOI: $10.31979 / \mathrm{mti} .2021 .2027$

Mineta Transportation Institute College of Business

San José State University

San José, CA 95192-0219

Tel: (408) 924-7560

Fax: (408) 924-7565

Email: mineta-institute@sjsu.edu

transweb.sjsu.edu/research/2027 


\section{ACKNOWLEDGMENTS}

The authors thank the following people for their important contributions to this project:

- Research assistant Xiomara Aguirre

- The experts interviewed for the project

- The MTI staff and anonymous reviewers 


\section{CONTENTS}

Acknowledments ......................................................................................................... vi

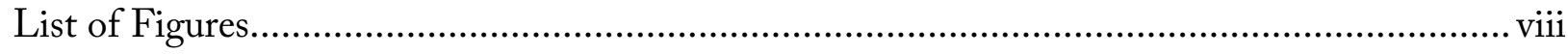

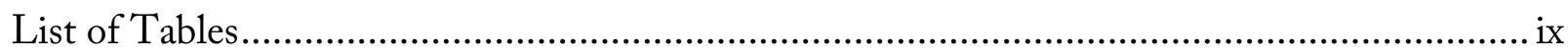

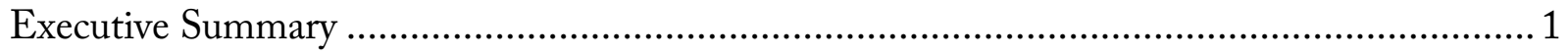

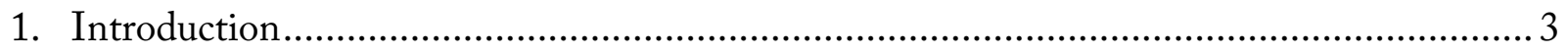

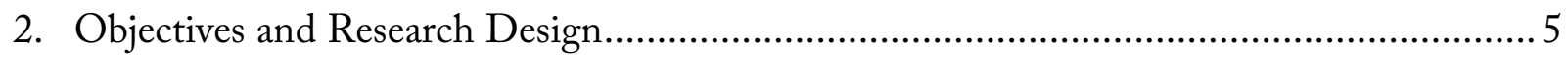

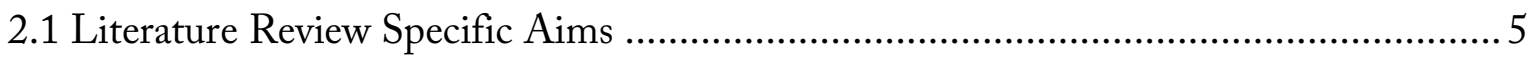

2.2 Quantitative Research Specific Aims ..................................................................

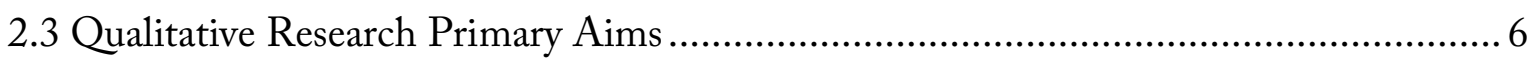

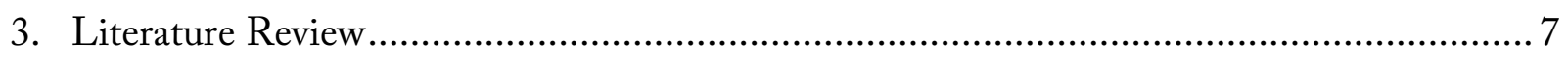

3.1 What are the Best Practices for Off-Site Mitigation? .............................................. 7

3.2 General Off-Site Compensatory Mitigation Best Practices ....................................... 8

3.3 How Is Equity Defined and Assessed in Common Off-Site Environmental

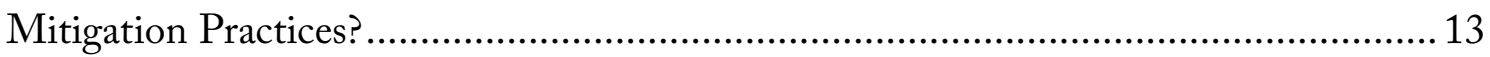

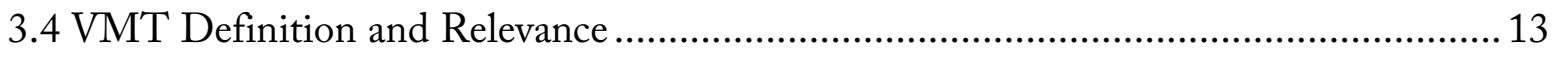

3.5 How Might Potential Off-Site VMT Mitigation Efforts Unduly Burden

Disadvantaged Communities? ................................................................................ 14

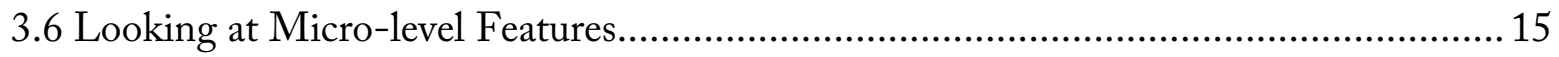

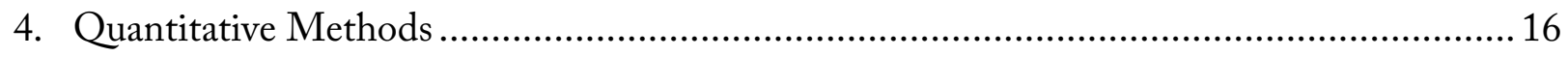

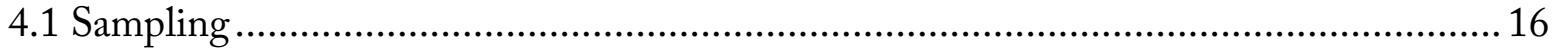

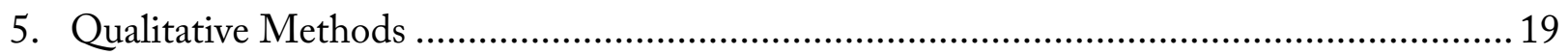

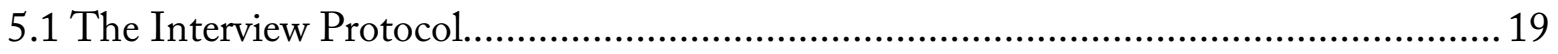

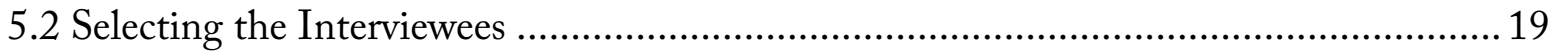

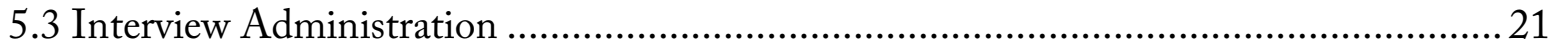

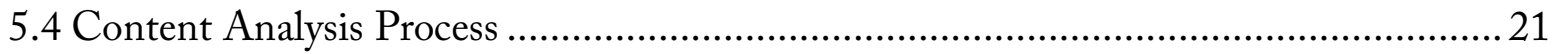

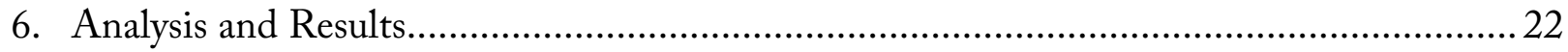

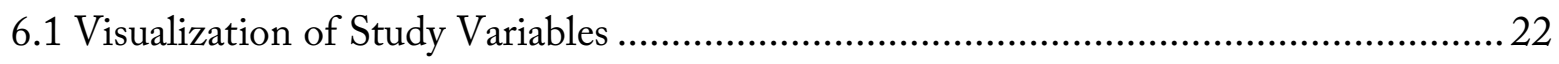

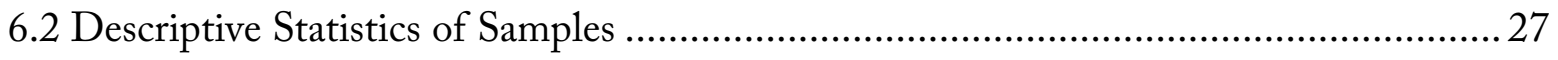

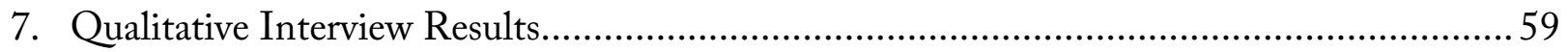

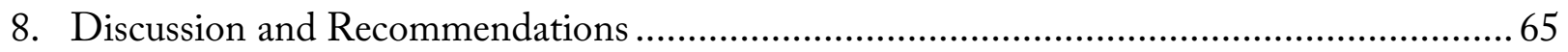

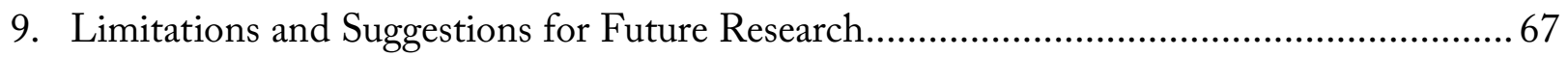

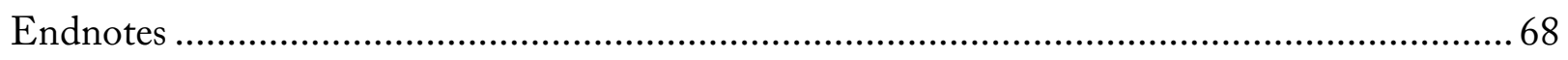

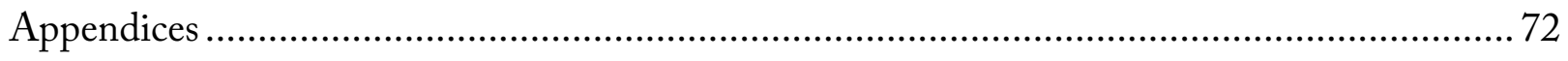




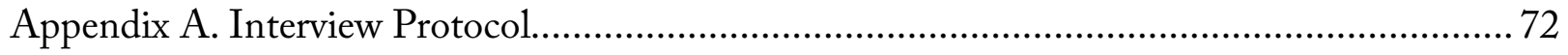

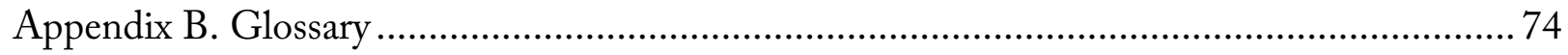

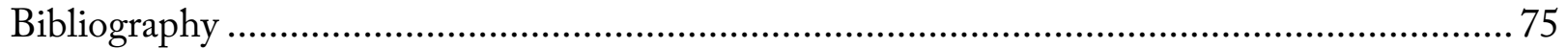

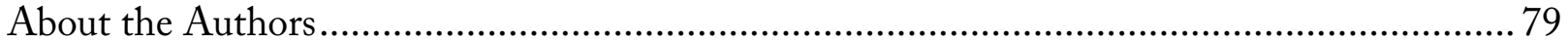




\section{LIST OF FIGURES}

Figure 1. Distribution of CalEnviroScreen Scores Across 60 Selected Census Tracts.............22

Figure 2. Distribution of Average State of Place Index Across 60 Selected Census Tracts.......23

Figure 3. Distribution of Average Annual Household VMT Across 60 Selected

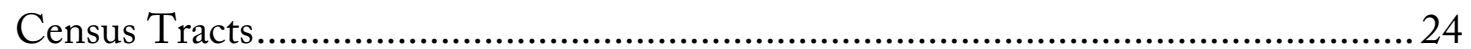

Figure 4. Distribution of Average Annual Household Income Across 60 Selected

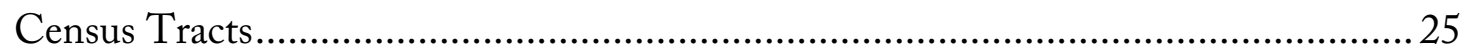

Figure 5. Distribution of Sprawl Index Across 60 Selected Census Tracts...........................26 


\section{LIST OF TABLES}

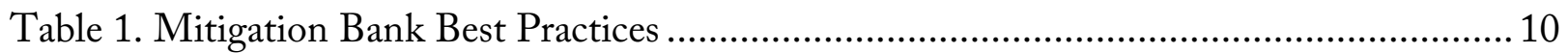

Table 2. In-lieu Fee Agreements Best Practices ................................................................... 11

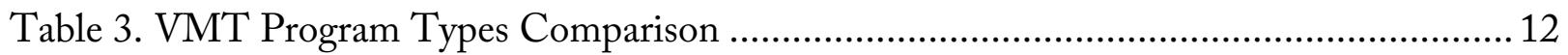

Table 4. List of Interview Participants and Title/Affiliation..................................................2 20

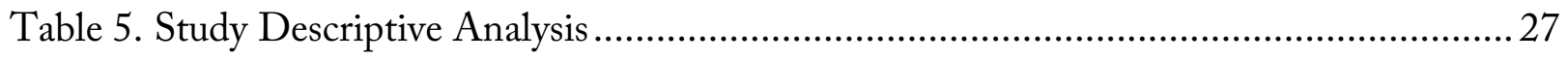

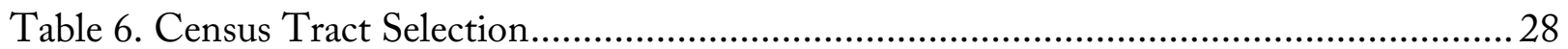

Table 7. Descriptive Statistics for Each Study Variable Comparing Disadvantaged vs.

Advantaged Communities .................................................................................... 29

Table 8. Independent Samples T-tests Comparing Disadvantaged vs. Advantaged

Communities across Study Variables ...................................................................... 30

Table 9. Stepwise Multiple Regression Model for VMT......................................................... 33

Table 10. Sprawl Index x State of Place Index One-Way ANOVA ………………................. 41

Table 11. Tukey HSB Post Hoc Test for Sprawl Index x State of Place Index ......................... 42

Table 12. State of Place Index x Income One-way ANOVA ................................................ 43

Table 13. Tukey HSB Post Hoc Test for State of Place Index x Income................................... 44

Table 14. Sprawl Index x State of Place Index x Income One-way ANOVA …………............. 45

Table 15. Tukey HSB Post Hoc Test for Sprawl Index x State of Place Index x Income......... 45

Table 16. State of Place Index x Transit One-way ANOVA .................................................50

Table 17. Tukey HSB Post Hoc Test for State of Place Index x Transit .................................51

Table 18. Sprawl Index x State of Place Index x Income $x$ Transit One-way ANOVA ............52

Table 19. Results of $Y$ hat (Predicted VMT) Across Place Types .............................................53

Table 20. Results of $Y$ hat (Predicted VMT) Across Place Types Comparing a

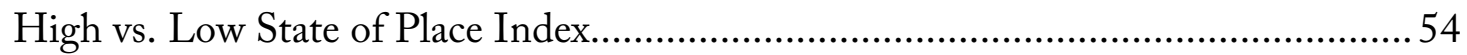

Table 21. Results of Y hat (Predicted VMT) Across Place Types Comparing a High vs. Low Income....................................................................................... 55

Table 22. Results of Y hat (Predicted VMT) Across Place Types Comparing Compact vs. Sprawled Places .56

Table 23. Results of Y hat (Predicted VMT) Across Place Types Comparing Good to Poor Transit Access.......................................................................................57

Table 24. Summary of Quantitative Results .......................................................................5 


\section{Executive Summary}

In 2013, Senate Bill 743 (SB-743) was passed in the California State Legislature with the purpose of advancing environmental quality in the state. One element of the bill involved a revision to the California Environmental Quality Act (CEQA), a statute requiring governmental agencies to identify the significant environmental impacts of their actions and to avoid or mitigate those impacts to the extent possible. Specifically, SB-743 mandated the adoption of vehicle-miles traveled (VMT) to replace level-of-service (LOS) as the standard for transportation impact analysis. SB-743 also allows for a regional approach to VMT mitigation through the concept of off-site banking or exchange programs that would let developers fulfill their mitigation obligations without having to incorporate changes in the immediate project site. Accompanying the logistical and administrative hurdles, the introduction of off-site VMT mitigation brings unintended equity challenges; namely, the distribution of benefits and burdens among disadvantaged communities. This study has two main objectives: (1) rigorously assess the equity challenges of off-site VMT mitigation efforts, and how disadvantaged communities might be adversely impacted; and (2) inform policy and practices related to off-site VMT mitigation and/or replacing LOS with VMT in CEQA processes.

This report employs a mixed-methods approach to explore the equity challenges of off-site VMT mitigation strategies and inform relevant policy and practices. For the quantitative analysis, a stratified random sample was used to select 60 census tracts within northern and southern California to perform a comparative analysis of VMT against sprawl, transit access, and macroscale built environment data. On the qualitative side, 19 professionals with expertise in the California Environmental Quality Act, level-of-service, and VMT were interviewed to gain insight on how local and state government have handled the transition process. Interview transcripts were coded, and common themes were extracted to support the report's conclusions. The report also reviews the literature of off-site mitigation strategies, drawing heavily on wetlands mitigation in the United States to summarize bank and exchange systems and overall best practices of off-site environmental mitigation.

The quantitative results first determined that the quality of the built environment (measured by the State of Place Index) has a significant relationship to VMT along with sprawl, income, transit access, and vehicle access. Furthermore, the results suggest that among all possible combinations, the lowest VMT levels were found in compact communities with lower incomes, a higher percentage of households without access to vehicles, and a higher State of Place Index. Our findings highlight how macroscale-built environment attributes, macroscale built environment attributes, transit access, and income, interact to impact VMT.

The quantitative results also provide context to explore the themes uncovered through the qualitative interviews, for example, how the implementation of microscale urban design features should adopt a perspective beyond simple installation to truly achieve VMT reduction. As seen through the qualitative interviews, many transportation professionals welcome VMT as a more appropriate measure for environmental impact mitigation, as well as additional benefits like the flexibility of banking systems to fund regional transportation projects. However, the same group expressed general concerns over the lack of a robust VMT body of knowledge, including tools to measure VMT impacts and evaluate the efficiency of mitigation strategies. 
This report highlights the scarcity of resources for local governments to carry out SB-743's changes but also the potential to address the gaps in policies and create a strong foundation for successful and equitable VMT mitigation. We recommend that the state should provide grants to expand the general body of knowledge and serve as the primary hub for local governments seeking more information. Also, statewide VMT banks and exchanges can be effectively managed at the regional level with local input to alleviate issues of interjurisdictional conflict and allow for community engagement. Finally, an equity framework should be incorporated in off-site mitigation efforts at all levels of government, acknowledging racial and socio-economic factors and the quality of microscale features in a community. 


\section{Introduction}

Since 1970, the California Environmental Quality Act (CEQA) has played a crucial role in mitigating the adverse impacts of development within the state. CEQA guidelines encompass a variety of elements, including environmental resources, cultural significance, and infrastructure systems. Senate Bill 743, enacted in 2013, reformed the process of assessing and mitigating transportation impacts of new developments by shifting to vehicle-miles travelled (VMT) mitigation instead of level of service (LOS) (or reducing automobile delay). While this shift is better aligned with the State's climate policy goals, it introduced several implementation challenges. Existing research has mostly focused on the management and approval process, structural and legal considerations, and case studies evaluating the transition from LOS to VMT. ${ }^{1,2,3}$ One pernicious concern regards the potentially-unintended-inequitable effects of VMT mitigation, at issue in this study.

SB 743 offers an opportunity to mitigate the transportation impacts of new developments regionally, which can potentially lead to the exacerbation and/or creation of new inequities. Given that common measures to reduce VMT, such as investments in new public and active transportation infrastructure, might be difficult to implement as part of proposed developments, SB 743 has led to exploring the concept of "off-site" mitigation efforts. Namely, developers can hypothetically choose to offset their mitigation requirements via "banking" (i.e., contributing to accounts held by local or regional authorities) or "exchanges" (i.e., choosing from a list of preapproved-or recommended-jurisdiction-wide mitigation projects). Accordingly, off-site mitigation can inadvertently and unduly burden already disadvantaged communities who may not end up benefiting from VMT reduction strategies tied to new developments, while potentially bearing the cost of increased VMT caused by such development. Specifically, there is a risk that banking and exchanges will not afford equitable access to the benefits tied to mitigation efforts, including increased built environment quality. Accordingly, there is a critical need to assess and identify potential mechanisms that would help ensure the proportionate and equitable distribution of transportation and urban design improvements tied to VMT mitigation.

Currently, a dearth of mechanisms is available to evaluate the equity impacts of off-site mitigation. However, existing VMT calculators cannot reliably estimate VMT mitigation tied to project-level built environment features. ${ }^{4}$ Current available tools only consider "macro-level" built environment features, such as density, land use mix, distance to the central business district (CBD), intersection density, and access to transportation. While these factors have been shown to contribute significantly to VMT, they do not capture the "microscale," streetscape urban design features, such as poor or missing sidewalks and/or curb cuts, non-active street-level uses, no street trees, etc., which have been tied to lower levels of walking and bicycling, and higher VMT.${ }^{5,6,7,8,9}$ Yet, arguably, it is these microscale urban design features that must be evaluated as part of ensuring the equity of VMT mitigation. ${ }^{10}$ Indeed, disadvantaged communities are less likely to have pedestriansupportive urban design, and as such, allowing off-site VMT impact mitigation may pose an unfair burden on such communities.

Further, existing VMT calculators have other shortcomings making them ineffective for assessing the equity of off-site mitigation programs. VMT calculators rely on travel demand and agentbased modeling, based on macro-level land use/transportation assumptions. Many are not 
calibrated to California-specific factors, and others require users to input external data that may be difficult to obtain. Most are unable to sufficiently account for how neighborhood-level vs. projectlevel features impact VMT, making it particularly difficult to estimate how much "mitigation" is required. Additionally, project-level attributes are often based on qualitative descriptions, rather than quantitative objective factors, and are considered "singularly" rather than "contextually" in a "whole is greater than the sum of its parts" manner. ${ }^{11,12,13}$

This study addresses the lack of effective mechanisms to evaluate the equity of off-site VMT mitigation projects by evaluating the impact of holistic, objective, micro-level urban design features that impact VMT, focused specifically within the context of California, using regression techniques rather than relying on agent-based modeling. This analysis also facilitates the differentiation between the impact of regional (i.e., land-use and transportation patterns) vs. block features (i.e., street-level built environment characteristics) on VMT. Further, it evaluates how the relationship between the built environment and VMT may be impacted by socio-economic factors (distinctive of disadvantaged communities).

Additionally, this report shares ideas and concerns discussed by transportation experts related to replacing LOS with VMT in CEQA, as well as the challenges and opportunities of VMT banking and exchange systems. Because California communities are at the beginning stages of developing and implementing off-site VMT mitigation strategies under SB 743, it is crucial to discuss challenges and opportunities from the standpoint of transportation experts, who are involved in these processes. The qualitative phase of this research also facilitated the interpretation of findings from the quantitative phase and developed recommendations that helped align results from the statistical analyses with the interview data. 


\section{Objectives and Research Design}

This study used a mixed methods research design to address a primary question: how can California ensure that VMT banking and exchange offset programs do not unduly burden disadvantaged communities, either through being negatively impacted by off-site mitigation efforts, or by not directly benefiting from VMT mitigation projects?

This study had two main objectives: (1) rigorously assess the equity challenges of off-site VMT mitigation efforts, and how disadvantaged communities might be adversely impacted; and (2) inform policy and practices related to off-site VMT mitigation and/or replacing LOS with VMT in CEQA processes. Each of the methods employed had further specific aims to help address the primary research objective, as subsequently presented:

\subsection{Literature Review Specific Aims}

We conducted a literature review to identify best practices in off-site environmental mitigation, focused on equity to address the following:

1. What are best practices for off-site environmental mitigation?

2. How is equity defined and assessed in common off-site environmental mitigation practices?

3. How might potential off-site VMT mitigation efforts unduly burden disadvantage communities?

\subsection{Quantitative Research Specific Aims}

This study employed multiple linear regression analysis to address two specific research questions:

1. How do socioeconomic characteristics tied to disadvantaged communities impact the relationship between the built environment and VMT?

Hypothesis: Disadvantaged neighborhoods with high concentrations of vulnerable populations are more likely to have poorer quality (less walkable and bikeable) built environments and accordingly, higher levels of VMT.

2. How do microscale urban design features (e.g., street-level built environment features such as trees, sidewalks, benches, etc.) interact with macroscale factors (e.g., land use mix, job access, transportation access, etc.) in impacting VMT?

Hypothesis: Microscale built environment features moderate the relationship between macroscale built environment factors and VMT-meaning, that the impact of micro-level urban design features on VMT depends on the macroscale patterns. 


\subsection{Qualitative Research Primary Aims}

The literature review and the preliminary findings from the quantitative analyses provided a basis for the third phase of this research which focuses on understanding the challenges and opportunities of replacing LOS with VMT in CEQA, and off-site VMT mitigation efforts from the standpoint of professionals involved in the implementation of SB 743. The primary aims are to:

1. Examine innovative approaches taken and challenges experienced by various communities in California tied to replacing LOS with VMT, and/or implementing off-site environmental impact mitigation.

2. Identify key points and gaps in our understanding of VMT as an environmental impact metric and implementation of off-site VMT mitigation strategies. 


\section{Literature Review}

Since its introduction in 1970, the California Environmental Quality Act (CEQA) has served as the bedrock for environmentally conscious development within the state. Intended to address the immense challenge of striking a balance between social and environmental demands, the CEQA process has long been a major discussion topic for both scholars and practitioners. The broad scope and loose statutory definitions of the CEQA has often given rise to multiple disputes between developers, environmentalists, governments, and residents. There have been countless disagreements and debates about how to implement the CEQA, leading to over 800 published decisions stemming from legal challenges. ${ }^{14}$ Recent changes to the CEQA guidelines, including the incorporation of Senate Bill 743 (SB 743) modifications, have fueled new discussions around this subject.

SB 743 was enacted by California legislature in 2013 to help align traffic analysis under the CEQA with the state's goal for environmentally sustainable development. ${ }^{15}$ The California Office of Planning and Research (OPR) developed guidelines in 2017 to further progress the goals of SB 743 , by calling for the depreciation of traffic level of service (LOS) analysis in favor of vehicle miles traveled (VMT) analysis. This transition has been received with mixed reviews: cities that prioritize infill development generally have policies and programs in place that align with VMT measures, leading to positive reception, whereas cities with lower-density developments question the suitability of SB 743 for their specific needs. ${ }^{16}$

As a result of SB 743, developers should now reduce VMT to mitigate significant environmental impacts under the CEQA. However, many strategies with the potential to significantly reduce VMT, such as investments in public transportation, can be difficult or cost-inefficient to implement near individual development sites. In response to this challenge, experts are considering off-site VMT mitigation strategies through banking and exchanges. Banking involves developers paying into a fund, which will be used at a later date by the government to invest in strategies to reduce VMT. On the other hand, an exchange would allow developers to select from a list of predetermined options to mitigate the VMT impact of their development. Both mechanisms would allow off-site VMT mitigation.

This chapter addresses the challenges around off-site environmental mitigation, including how to do so equitably, and explores best practices surrounding current mitigation methods. This chapter aims to translate how existing examples of successful off-site environmental mitigation might be applied to the implementation of equitable, off-site VMT mitigation.

Literature reviewing mitigation measures tied specifically to VMT is sparse, given the relatively recent shift from LOS to VMT mitigation within the CEQA. This report aims to identify and address gaps in VMT mitigation research. Additionally, this report will evaluate how more established mitigation measures around greenhouse gas emissions and wetlands might help inform VMT mitigation efforts moving forward.

\subsection{What are the Best Practices for Off-Site Mitigation?}

CEQA guidelines found in the California Code of Regulations provide general guidelines for mitigation measures regardless of the impacted resource area. Lead agencies are responsible for 
ensuring a nexus and rough proportionality between the significant impact being addressed and feasible, fully enforceable mitigation measures. ${ }^{17}$

Offset policies should follow the hierarchy of avoidance, minimization, and compensatory mitigation in considering the best course of action to address significant environmental impacts. ${ }^{18}$ Off-site environmental mitigation serves as a type of offset policy, where ecological restoration efforts are placed outside the impact area. Although best practices for off-site mitigation are not specifically listed within CEQA guidelines, off-site mitigation tools have been employed with relative success in wetlands-loss programs and pollution-offset strategies such as greenhouse gas exchange markets across the country.

\section{Best Practice Example: Wetlands}

The goal of wetlands mitigation in the United States is to avoid net loss of wetlands' ecological functions; however, the policy in practice has equated to a no-net loss of acreage. ${ }^{19}$ Wetlands offset policies follow a general hierarchy of avoidance and minimization, before proceeding to compensatory mitigation, such as covering loose sediment with tarps to prevent erosion, and timing project work to avoid nesting and spawning seasons of local species. ${ }^{20}$

Compensatory mitigation for wetlands utilizes three mechanisms under the federal Clean Water Act: permittee-responsible mitigation, mitigation banks, and in-lieu fee mitigation. ${ }^{21}$ Permitteeresponsible mitigation involves restoration, establishment, enhancement, or preservation of aquatic resources; mitigation banks use a credit system in designated restoration areas to compensate for impacts; and in-lieu fee mitigation involves funding public agencies and non-profit organizations involved in mitigation projects. ${ }^{22}$ Concerns have been raised over compensatory mitigation over the years, such as questioning the ability of constructed wetlands to support native species or reproduce unique features such as bogs and fens. ${ }^{23}$ These criticisms have led to the US Army Corps of Engineers, Environmental Protection Agency, and the National Research Council to refine wetland mitigation statutes to provide additional guidelines for monitoring requirements, adaptive management, and watershed-scale site selection, to increase the success of effective mitigation.

\subsection{General Off-Site Compensatory Mitigation Best Practices}

Compensatory mitigation should occur in areas adjacent or contiguous to the impact area. ${ }^{24}$ Delicate ecosystem processes may not have the same level of function in new environments. Federal guidelines acknowledge that adjacent areas may not be economically or physically available and encourage developers to seek similar environmental parameters of the impact site for off-site mitigation.

Off-site mitigation should be consistent with regional watershed plans. This guideline considers the specific functions of the impacted wetland on a larger scale such as species habitat and flood control to ensure satisfactory compensation. Adding to the first guideline of mitigation location, the proposed site should be located as close as possible to the impact site to ensure ecoregion conformity. 
Off-site mitigation should be sustainable in the context of land use and natural processes. Mitigation site suitability should be determined by its ability to mimic impacted landscape function and processes while acknowledging surrounding land use with buffers and other site restrictions.

Off-site mitigation goals should be feasibly monitored for performance. This includes creating clear and measurable goals to evaluate mitigation success. Success in off-site mitigation includes "no-net loss" policy and the replacement of impacted ecological functions.

\section{Mitigation Banking}

Mitigation banking has found its footing as a growing market-based, off-site mitigation tool that brings developers and conservationists to a middle-ground. In the context of wetlands mitigation, the US Army Corps of Engineers defines mitigation banking as wetland restoration, creation, enhancement, or preservation when compensatory measures cannot be done on-site, or ecological benefits would be greater off-site. ${ }^{25}$ Support from agencies such as the US Army Corps of Engineers have helped develop best practices for wetlands mitigation banking (table 1).

Codified by the 1990 Mitigation Memorandum of Agreement, permit applicants are required to demonstrate reasonable effort in avoiding, or minimizing, environmental impacts before considering compensatory mitigation measures. Regulations have been placed to prevent developers from glossing over avoidance of impacts or on-site mitigation measures, however, opponents have argued that regulatory "sequencing" has made the initial permitting process tedious.

In practice, mitigation banking involves developers purchasing credit as opposed to conducting environmental restoration and maintenance. Mitigation banks across the United States vary with respect to stakeholder ownership. For example, mitigation banks in California can be co-funded by developers, and owned by private companies; whereas in North Carolina, mitigation banks are largely handled by the state through their Environmental Enhancement Program (EEP). 
Mitigation bank site acquisition should incorporate ecological, social, and economic elements. Factors that go into site selection for off-site wetlands mitigation commonly include similarity in biological character compared to the impacted site, compatibility with regional land use planning, and economic potential or cost-effectiveness. For example, one of the criteria used by the North Carolina EEP is greatest potential ecological return on investment as an economic efficiency measure. A Mitigation Banking Instrument is required to establish a mitigation bank, subject to review and approval by the Mitigation Bank Review Team.

Mitigation banks should incorporate the quantification of assets and functions to generate credits. Mitigation programs generate tangible benefits that are evaluated and used to measure the value of a credit. These credits are essentially units of environmental benefit that are derived from conservation and restoration actions. The credits should then serve as currency, to be exchanged with developers in mitigation bank systems. For wetlands mitigation, the Habitat Evaluation Procedure is an assessment tool that determines the suitability of an ecosystem for a selected indicator species. The result of the Habitat Evaluation Procedure is a numeric value that assists in determining the appropriate level of mitigation needed to compensate for habitat loss. According to the US Environmental Protection Agency, bank sponsors and regulatory agencies are responsible for quantification of aquatic functions in a wetlands bank and the resulting assignment of credits.

Credit values and ratios must be determined before transactions are made. In a mitigation bank system, the cost structures that determine credit values can be affected by asset quality, unique mitigation skills, mitigation failure risk, and bank objectives. These structures ultimately establish the level of mitigation required for impacted sites and should be resolved before creating a mitigation bank.

Source: Bruce McKenny, "Environmental Offset Policies, Principles, and Methods: A Review of Selected Legislative Frameworks," Biodiversity Neutral Initiative, published March 30, 2005, 19, https://www.foresttrends.org/publications/environmental-offset-policies-principles-and-methods-a-review-of-selected-legislativeframeworks-2/; Stephen Crooks and Laure Ledoux, "Mitigation banking: Potential applications in the UK," Centre for Social and Economic Research on the Global Environment, published January 2000, page 7, https://www.researchgate.net/publication/292866030 Mitigation banking Potential applications in the UK; "Federal Guidance for the Establishment, Use and Operation of Mitigation Banks." EPA. Environmental Protection Agency, November 28, 1995. https://www.epa.gov/cwa-404/federal-guidance-establishment-use-andoperation-mitigation-banks

Codified by the 1990 Mitigation Memorandum of Agreement, permit applicants are required to demonstrate reasonable effort in avoiding, or minimizing, environmental impacts before considering compensatory mitigation measures. ${ }^{26}$ Regulations have been placed to prevent developers from glossing over avoidance of impacts or on-site mitigation measures; however, opponents have argued that regulatory "sequencing" has made the initial permitting process tedious. ${ }^{27}$

In practice, mitigation banking involves developers purchasing credit as opposed to conducting environmental restoration and maintenance. ${ }^{28}$ Mitigation banks across the United States vary with respect to stakeholder ownership. For example, mitigation banks in California can be co-funded 
by developers, and owned by private companies; whereas in North Carolina, mitigation banks are largely handled by the state through their Environmental Enhancement Program (EEP). ${ }^{29}$

\section{In-lieu Fee Agreements}

In-lieu fee agreements are agreements between a developer and sponsor, where the developers will pay a fee to a mitigation sponsor, usually one with existing mitigation projects, to satisfy a developer's compensatory requirements. ${ }^{30}$ This differs from a mitigation bank, in that developers are even less involved in the mitigation project, essentially shifting the burden of mitigation to the mitigation sponsor after the fee is paid. Due to lax standards and poor monitoring of sponsor agencies in the past, the US Army Corps of Engineers developed federal requirements for establishing in-lieu fee agreements:

Table 2. In-lieu Fee Agreements Best Practices

Mitigation sponsors must be qualified to provide compensatory mitigation. Per federal guidelines, sponsors must provide a summary of experience and qualifications to provide mitigation services.

Mitigation terms fully rest upon mitigation sponsors accepting the in-lieu fee. Mitigation terms include describing the type of mitigation to be done, creating monitoring provisions and performance standards, and determining fee and credit structures.

Source: McKenny, Bruce, "Environmental Offset Policies, Principles, and Methods: A Review of Selected Legislative Frameworks," Biodiversity Neutral Initiative, published March 30, 2005, page 21, https://www.foresttrends.org/publications/environmental-offset-policies-principles-and-methods-a-review-of-selected-legislativeframeworks-2/

Although discussed mainly in wetlands mitigation, the best practices listed previously serve as the foundation for mitigation across other sectors. For example, renewable energy mitigation draws its framework from the regulations created for wetlands mitigation by the Army Corp of Engineers and Environmental Protection Agency. ${ }^{31}$ In solar energy specifically, the three mechanisms of offsite mitigation (permittee-responsible mitigation, mitigation banks, in-lieu fee agreements) are available, although no major solar panel projects in California have utilized an in-lieu fee agreement so far. ${ }^{32}$ Thus, any forthcoming VMT mitigation measures should also abide by these best practices standards.

In April 2020, Fehr and Peers published a white paper detailing VMT mitigation under SB 743. ${ }^{33}$ The white paper draws parallels from mitigation programs from other areas of the environmental and transportation sectors, to explain the impact fee, exchange, and bank program types. Fehr and Peers also provided legal background, and the basic implementation process for each of the program types. Lastly, the paper details the key differences and potential hurdles for each of the program types.

Table 3 s reproduced from the Fehr and Peers white paper and provides a summary of the pros and cons regarding VMT impact fees, exchanges, and banks 
Table 3. VMT Program Types Comparison

\begin{tabular}{|c|c|c|}
\hline Program Type & Pros & Cons \\
\hline Impact Fee & $\begin{array}{l}\text { - Common and accepted practice } \\
\text { - Accepted for CEQA mitigation } \\
\text { - Adds certainty to development costs } \\
\text { - Allows for regional scale mitigation } \\
\text { projects } \\
\text { - Increases potential VMT reduction } \\
\text { compared to project site mitigation } \\
\text { only }\end{array}$ & $\begin{array}{l}\text { - Time consuming and expensive to } \\
\text { develop and maintain } \\
\text { - Requires strong nexus } \\
\text { - Increases mitigation costs for developers } \\
\text { because it increases feasible mitigation } \\
\text { options } \\
\text { - Limited to jurisdictional boundary } \\
\text { unless a regional authority is created } \\
\text { - Uncertainty about feasibility and } \\
\text { strength of nexus relationship between } \\
\text { VMT and pedestrian, bicycle, and transit } \\
\text { projects (especially in suburban/rural } \\
\text { jurisdictions) }\end{array}$ \\
\hline Exchange & $\begin{array}{l}\text { - Limited complexity } \\
\text { - Reduced nexus obligation } \\
\text { - Expands mitigation to include costs } \\
\text { for programs, operations, and } \\
\text { maintenance } \\
\text { - Allows for regional scale mitigation } \\
\text { projects } \\
\text { - Allows for mitigation projects to be } \\
\text { in other jurisdictions } \\
\text { - Increases potential VMT reduction } \\
\text { compared to project site mitigation } \\
\text { only }\end{array}$ & $\begin{array}{l}\text { - Requires 'additionality' } \\
\text { - Potential for mismatch between } \\
\text { mitigation needs and mitigation projects } \\
\text { - Increases mitigation costs for developers } \\
\text { because it increases feasible mitigation } \\
\text { options } \\
\text { - Unknown timeframe for mitigation life } \\
\text { - Effectiveness depends on scale of the } \\
\text { program }\end{array}$ \\
\hline Bank & $\begin{array}{l}\text { - Adds certainty to development costs } \\
\text { - Allows for regional scale projects } \\
\text { - Allows for mitigation projects to be } \\
\text { in other jurisdictions } \\
\text { - Allows regional or state transfers } \\
\text { - Expands mitigation options to } \\
\text { include costs for programs, } \\
\text { operations, and maintenance } \\
\text { - Increases potential VMT reduction } \\
\text { compared to project site mitigation } \\
\text { only }\end{array}$ & $\begin{array}{l}\text { - Requires 'additionality' } \\
\text { - Time consuming and expensive to } \\
\text { develop and maintain } \\
\text { - Requires strong nexus } \\
\text { - Political difficulty distributing } \\
\text { mitigation dollars/projects } \\
\text { - Increases mitigation costs for developers } \\
\text { because it increases feasible mitigation } \\
\text { options } \\
\text { - Unknown timeframe for mitigation life } \\
\text { - Effectiveness depends on scale of the } \\
\text { program }\end{array}$ \\
\hline
\end{tabular}

Source: Fehr and Peers. "VMT Mitigation Through Fees, Banks, \& Exchanges." published April 2020, page 4-5. https://www.fehrandpeers.com/wp-content/uploads/2020/04/VMT-Fees_Exchanges_Banks-WhitePaper_Apr2020.pdf 


\subsection{How Is Equity Defined and Assessed in Common Off-Site Environmental Mitigation Practices?}

Environmental equity has been broadly defined as a distribution of healthy physical environments, and protection from environmental damage across racial and socioeconomic groups. ${ }^{34}$ However, equity in VMT mitigation requires an in-depth analysis of the distribution of benefits and costs. For example, accessibility is defined as proximity to efficient transport systems, and is used as an indicator of spatial equity in transportation planning. ${ }^{35}$ Mobility equity is then assessed by examining the extent of access different population groups will have to jobs, housing, and other urban services. Another key dimension of mobility equity is related to the environmental and health impacts of transportation. By definition, an equitable transportation system provides access to mobility and economic opportunity while minimizing environmental burdens, such as air pollution and GHG emissions. If an infrastructure improvement project is proposed to improve mobility equity, an analysis of the distribution of costs and benefits of the project on various populations groups should be conducted. For example, when it comes to air quality and greenhouse gas emissions, the distribution of program costs and health impacts are examined using equity analysis. ${ }^{36}$ These examples point to the essence of equity: ensuring fairness in receiving benefits and bearing the burdens of mitigation.

Wetland mitigation can also be observed through an equity lens. An equity analysis of wetlands mitigation in western Washington State revealed a tendency of off-site mitigation to occur in lower-density areas, in comparison to impact sites. ${ }^{37}$ This means that off-site wetland mitigation efforts tend to relocate wetlands, and by extension their ecosystem service benefits, from densely populated urban areas to lower density rural areas. The study recommended that regulatory agencies develop and maintain a spatial database of wetland mitigation projects and consider the impacts of such projects on human populations. ${ }^{38}$

Cap-and-trade programs to reduce greenhouse gas (GHG) emissions also involve important equity considerations. The carbon trading component of cap-and-trade programs allows polluters to buy, or exchange carbon credits. For example, a high-emitting company in California can use an off-site or out-of-state project to meet their compliance obligations. Environmental justice communities are concerned about the equity implications of such programs since polluting industries tend to be located near predominately minority and low-income neighborhoods. Conversely, on-site GHG emission mitigations can yield public health and environmental equity co-benefits, off-site mitigation through carbon trading emphasizes reduced overall emissions. This means that overall emissions can drop, but localized GHG emissions can increase. ${ }^{39}$

\subsection{VMT Definition and Relevance}

Vehicle miles traveled (VMT) is the measure of the amount of travel by vehicle over a certain period of time. ${ }^{40}$ In the context of transportation planning, VMT is used as a travel demand measure, and helps forecast congestion, analyze road capacities, and identify travel behavior. ${ }^{41}$ Several agencies have developed quick, cost-effective methods known as "sketch tools" to measure a project's impact on VMT. These sketch tools commonly ask for project-specific characteristics to determine VMT, such as land use and existing number of trips that pass through the project site. $^{42}$ 


\subsection{How Might Potential Off-Site VMT Mitigation Efforts Unduly Burden Disadvantaged Communities?}

One objective of this research project is to explore the equity implications of allowing for off-site VMT mitigation and identify potential burdens that might be placed on disadvantaged communities due to those off-site mitigation measures. Some specific strategies provided by the OPR include providing higher transit accessibility; increasing density and mixed-use projects; incorporating affordable housing; and incorporating transportation demand management (TDM) measures such as variable pricing, public transit, and bicycle amenities. ${ }^{43}$

Constructing transit-oriented communities is a highly favored VMT mitigation strategy found in SB 743, but it also presents a potential equity issue. Research suggests that transit-oriented development could lead to higher housing costs and consequently to the displacement of lowincome households. ${ }^{44}$ Furthermore, displaced, low-income households that rely on job opportunities in city centers find an increase in their VMT due to expensive housing around transit areas. ${ }^{45}$ These disadvantaged communities experience higher rates of traffic crashes, increased greenhouse gas emissions, and limited access to healthcare and other essential services. ${ }^{46}$ Therefore, it is important to integrate affordable housing strategies into transit-oriented development, and systematically analyze the potential impacts of such development on low-income and minority communities.

The distribution of built environment features in VMT mitigation programs are also an area of concern. Improving the walking experience is a key element in developing transit-oriented communities. Features such as streetlights, paved pathways, and benches beautify the area and encourage active transportation and transit ridership. ${ }^{47}$ However, low-income communities are often overlooked in implementing these small additions that improve daily mobility, physical activity, and safety. ${ }^{48}$

Environmental justice communities often refer to a combination of factors (with simultaneous and self-reinforcing relationships) that impact community health and well-being. For example, West Oakland - a neighborhood with high prevalence of poverty and a high percentage of minority populations in the Bay Area—suffers from a disproportionately higher level of exposure to air pollution. West Oakland also has a large transit- and walking-dependant population but suffers from inhospitable and inaccessible streets for walking. ${ }^{49}$ The combination of these factors has resulted in poor health and well-being outcomes for the community.

To promote equity in the distribution of VMT mitigation benefits for disadvantaged communities, it is important to engage such communities in the mitigation process in a meaningful way. Literature on ecological restoration reveals there is an overreliance on basic cost-benefit analysis tools, which often fail to capture the distribution of mitigation effects. ${ }^{50}$ The literature calls for a deeper stakeholder analysis, beyond local attitude assessments, and an active incorporation of local concerns in mitigation measures. Strategies to bring disadvantaged communities into the planning process include bringing in community representatives or employing community members as consultants. ${ }^{51}$ 


\subsection{Looking at Micro-level Features}

The literature surrounding VMT assessment suggests that evaluation generally depends on macrolevel variables such as population, transit accessibility, road density, and employment availability. ${ }^{52}$ In turn, current mitigation measures focus on reducing VMT at the macroscale. There is a lack of data on how micro-level built environment features, including benches, street lighting, pedestrian signage, and sustainable transportation facilities, impact VMT. Although these micro-level features would typical be elements of a VMT mitigation plan, VMT calculators do not account for the impacts of these micro-level features on mitigation. ${ }^{53}$

The effect of project-level built environment features on mitigation success and equity has not been sufficiently discussed in VMT mitigation. However, previous research suggests that macroscale built environment characteristics have some bearing on travel habits that may affect VMT. In a study conducted in the Zhongshan Metropolitan Area, neighborhood-level built environment features, such as bus service coverage, and street level density, strengthen models predicting vehicle ownership and travel patterns. ${ }^{54}$ In a closer look at micro-level features, a qualitative analysis of the impact of bench installation found that benches encouraged physical mobility among senior citizens, and contributed to a positive perception of neighborhood safety in reference to Jane Jacob's theory of social inclusion. ${ }^{55}$ Another study conducted in Seoul, South Korea also attempted to develop objective measures of "livable streets" and other theories related to strong, street-level walkability. Survey results concluded that although meso-scale variables like land use diversity and presence of transit stations have a significant impact on pedestrian satisfaction, the contribution of microscale variables, such as trees, lamps, and bus lanes, to the walking experience is not negligible. ${ }^{56}$

The purpose of this report is to analyze the distribution of off-site VMT mitigation projects, and their effects on communities. Looking into macro-level elements such as land use is an essential component of developing mitigation measures; however, the field has widely glossed over the details of more macroscale built environment features. This report aims to generate a quantitative measure of microscale urban design elements, to create a framework that could better assess the efficacy of VMT mitigation and access to mitigation benefits. 


\section{Quantitative Methods}

\subsection{Sampling}

This study focused on a sample of communities within northern and southern California. We employed a stratified random sample to select 60 census tracts that varied along a continuum of "vulnerability" as defined by the CalEnviroScreen 3.0 tool developed as part of the Disadvantaged Communities Act (SB 535). Strata were identified for the entire continuum using the mean and standard deviation, with one stratum being subdivided into two, due to the threshold for advantaged/disadvantaged per SB 535 falling within that specific stratum. We then selected a representative random sample from each of the advantaged and disadvantaged strata, for a total 60 census tracts.

\section{Dependent Variable: Vehicle Miles Traveled (VMT)}

VMT data were derived from the Center of Neighborhood Technology's (CNT) Housing and Transportation Affordability Index (H+T Index) Database at the census block group level, which was the smallest unit of analysis available for this variable. CNT derives its measure of VMT by utilizing the 2010-2012 California Household Travel Survey (CHTS), which consists of one-day travel diaries for 42,420 households between January 2012 and February 2013. ${ }^{57}$ CNT's VMT measure is calculated by first tallying the road distances of all trips made with personal travel modes and, if necessary, dividing the trip distances by the number of family members traveling together to capture vehicle miles traveled and not person miles traveled. CNT made several adjustments to the data, namely by removing reported vehicle trips without an associated road distance, or trips that exceeded a certain threshold, to determine airline and road distances. CNT also removed travel trips and departures that were exceptional from typical habits as outliers in the final dataset.

\section{Independent Variable: Macroscale Built Environment Data}

This study used a "Sprawl Index" to measure aspects of the macroscale built environment, and land-use characteristics, known to be tied to VMT. The Sprawl Index was developed by Reid Ewing and his team at the University of Utah, with the support of Smart Growth America, the Ford Foundation, and the National Cancer Institute at the National Institutes of Health. ${ }^{58}$ The Sprawl Index is based on measures of residential and employment density, neighborhood mix of homes, jobs and services, strength of activity centers and downtowns, and the accessibility of the street network. The Sprawl Index is measured at the census tract level.

Although data on these parameters were available from other sources, we chose to use this measure (Sprawl Index) to capture the macroscale aspects of the built environment for this study, as it helped to simplify the model and reduce potential multicollinearity issues. At the same time, the SGA Sprawl Index is easily broken down into its subcomponents, making relevant findings easy to interpret and translate into evidence-based practice and policy guidelines, including the implementation of SB 743. 


\section{Independent Variable: Access to Transit}

While the SGA Sprawl Index captured aspects of the macroscale built environment tied to land use mix and density, it did not incorporate a measure of transit access, which is known to impact VMT. Accordingly, we used the Environmental Protection Agency's (EPA) measure of transit access, which calculates the aggregate frequency of transit services within 0.25 miles of a block group boundary per hour during the evening peak period.

\section{Independent Variable: Macroscale Built Environment Data}

This study used the State of Place (SoP) Index to measure aspects of microscale built environment characteristics, such as the presence of sidewalks, bike lanes, curb cuts, street trees, public furniture, etc., that are thought to moderate the relationship between microscale built environment factors and VMT. The SoP Index is composed of over 150 built environment features based on a modified version of the Irvine Minnesota Inventory (IMI), a widely-used objective and reliable audit tool designed to measure built environment features tied to active transportation. The SoP Index measures the quality of a place and walkability/bikeability using a series of validated algorithms. ${ }^{59,60}$ The SoP Index aggregates IMI data into a score from 0-100 and has ten sub-indices measuring key aspects of urban design empirically linked to walking and physical activity-including density, connectivity, urban form, proximity to non-residential locations, parks and public spaces, recreational facilities, pedestrian and bicyclist amenities, traffic safety, aesthetics, and personal safety.

Macroscale built environment data was collected for all street blocks - the area between two intersections on both sides of the street - using machine learning techniques developed by State of Place. First, State of Place identifies all intersections, and their corresponding line files, within the geographical area of interest using a geographical information system such as ArcGIS or Q-GIS. Then, a series of algorithms are run to extract digital images from a street block via a street-level imagery repository, such as Google Street View. Multiple images are extracted for each block to ensure full coverage of all urban design features for that block. State of Place then uses proprietary visual machine learning models to detect over 150 urban design features from each image. Additionally, some other urban design features are extracted from open-source data, such as Open Street Maps. Then, additional machine and deep learning algorithms are deployed to aggregate all this data into the State of Place Index.

\section{Control Variables: Socio-economic Status}

A variety of control variables were included in this study to account for known factors that impact VMT, so that we could isolate the effects of the relationship between macro and micro built environment variables on VMT. Additionally, the study aimed to understand the relationship between various factors of socio-economic status (SES) and VMT.

First, we used the CalEnviroScreen 3.0 (CES) measure of vulnerability, which includes risk factors for pollution burden, including exposures and environmental hazards; population characteristics, including prevalence of chronic diseases tied to pollution exposure; and traditional factors of SES, including race, ethnicity, and household income. CES is measured at the census tract level. We 
also included a separate measure of household income from the American Community Survey, extracted at the census block group level. Further, we included a measure of vehicle access derived from the Bureau of Transportation based on the number of households without vehicle access. 


\section{Qualitative Methods}

Through the interview phase, the research team learned from the experiences of experts in the field of transportation, and validated findings from previous phases of research. This chapter explains the processes we followed to obtain and analyze the interview data.

\subsection{The Interview Protocol}

We designed a semi-structured interview protocol, based on the preliminary findings from the previous phases of research and in consultation with the informal advisors from the California Department of Transportation. The interview questions were open-ended and covered topics such as: implementation and equity challenges and opportunities involved with SB 743 and off-site VMT impact mitigation; factors to be considered to ensure the equitable and proportionate distribution of transportation and urban design improvements tied to VMT mitigation; VMT estimation tools; the role of local, regional and state level organizations; and transportation improvement efforts undertaken to address the needs of disadvantaged communities. Because California communities are still in the beginning stages of replacing LOS with VMT and developing strategies for off-site VMT mitigation, the interview phase of this research was exploratory. Open-ended questions were thus appropriate for our purpose. Error! Reference source not found. provides the entire interview protocol.

\subsection{Selecting the Interviewees}

To identify the best informants, the research team first contacted the informal advisors from the California Department of Transportation. The interviewer then used the snowball sampling technique to recruit knowledgeable participants representing areas in northern and southern California, as well as experts from the California Department of Transportation. The interviewer quickly found that California transportation professionals who have been involved in the implementation of SB 743 and discussions of off-site VMT mitigation resemble a close-knit community. Most of these experts participate in the statewide "VMT Exchange Working Group" meetings to learn about innovative practices in other jurisdictions. The interviewer contacted the individuals who were recommended for their knowledge about the subject, innovative practices, early action to mitigate VMT, or success in obtaining grants for relevant projects.

In total, formal interviews were conducted with nineteen experts. Additionally, several informal interviews were completed with Deputy Director of Sustainability at California Department of Transportation Ellen Greenberg and other leaders to help identify participants and design or refine the final interview protocol. Each interview took approximately one hour. In some cities, the interviewer conducted group interviews because the invited interviewee recruited or recommended additional people with diverse but relevant experiences to participate in the discussion. In addition to the interviews with experts representing cities, a second smaller set of interviews with state administrators explored their perceptions about the implementation of SB 743, and the role the State of California can play in facilitating off-site VMT mitigation.

Table 4 presents the names and affiliations of all formal interviewees. 
Table 4. List of Interview Participants and Title/Affiliation

\begin{tabular}{|c|c|}
\hline Name & Title/Affiliation \\
\hline Maureen Gardiner & Senior Traffic Engineer, City of San Diego \\
\hline Julia Chase & Senior Planner, City of San Diego \\
\hline Wade Weitgrefe & $\begin{array}{l}\text { Principal Planner, Transportation Team Manager, City and County of San } \\
\text { Francisco }\end{array}$ \\
\hline Ramses Madou & $\begin{array}{l}\text { Division Manager of Planning, Policy, and Sustainability for the } \\
\text { Department of Transportation, City of San José }\end{array}$ \\
\hline Agustin Cuello León & Engineer, Department of Transportation, City of San José \\
\hline David Somers & $\begin{array}{l}\text { Supervising Transportation Planner at City of Los Angeles, Department of } \\
\text { Transportation }\end{array}$ \\
\hline Fedolia “Sparky” Harris & Principal Planner, City of Sacramento \\
\hline Maurice Eaton & Senior Transportation Planner, Caltrans District 11 \\
\hline Maricela Salazar & Transportation Analyst, Sacramento Area Council of Governments \\
\hline Krute Singa & Principal Regional Planner, Metropolitan Transportation Commission \\
\hline Paul Backstrom & Manager, Transportation Planning at LA Metro \\
\hline Rob Swierk & $\begin{array}{l}\text { Principal Transportation Planner, Santa Clara Valley Transportation } \\
\text { Authority (VTA) }\end{array}$ \\
\hline Ronald T. Milam & Director of Evolving the Status Quo, Fehr \& Peers \\
\hline Matt Kelly & Senior Transportation Planner, Contra Costa Transportation Authority \\
\hline John Olejnik & Senior Transportation Planner, Caltrans \\
\hline Bruce Griesenbeck & Data and Analysis Manager, Sacramento Area Council of Governments \\
\hline Michael Navarro & $\begin{array}{l}\text { District } 6 \text { Deputy District Director, Planning, Local Programs, and } \\
\text { Environmental Analysis }\end{array}$ \\
\hline Eric Olson & $\begin{array}{l}\text { Senior Transportation Engineer, District } 6 \text { Technical Planning Branch at } \\
\text { Caltrans }\end{array}$ \\
\hline Emanuel Alforja & Assistant Engineer, Traffic San Diego \\
\hline
\end{tabular}




\subsection{Interview Administration}

All interviews were administered via Zoom Video Communications. The interviews lasted approximately one hour each. All interviews were audio-recorded and transcribed by Zoom. The research team reviewed and revised the transcriptions to ensure accuracy.

\subsection{Content Analysis Process}

We used a combined deductive and inductive process to identify critical themes for analysis, and then systematically coded the transcripts for these themes. 


\section{Analysis and Results}

\subsection{Visualization of Study Variables}

Figures 1-5 display the averages of each study variable used in the quantitative analysis: State of Place Index, Annual Household VMT, Sprawl Index, CalEnviroScreen Score, and Annual Household Income. Each map was produced in ESRI's ArcGIS Pro and utilizes the Jenks Natural Breaks optimization method to classify the results. Figure 1 displays the 60 selected census tracts for this report, which are placed relative to each other, but does not reflect the true location nor actual size of each census tract.

Figure 1. Distribution of CalEnviroScreen Scores Across 60 Selected Census Tracts (Higher Score Indicates Higher Level of Burden)

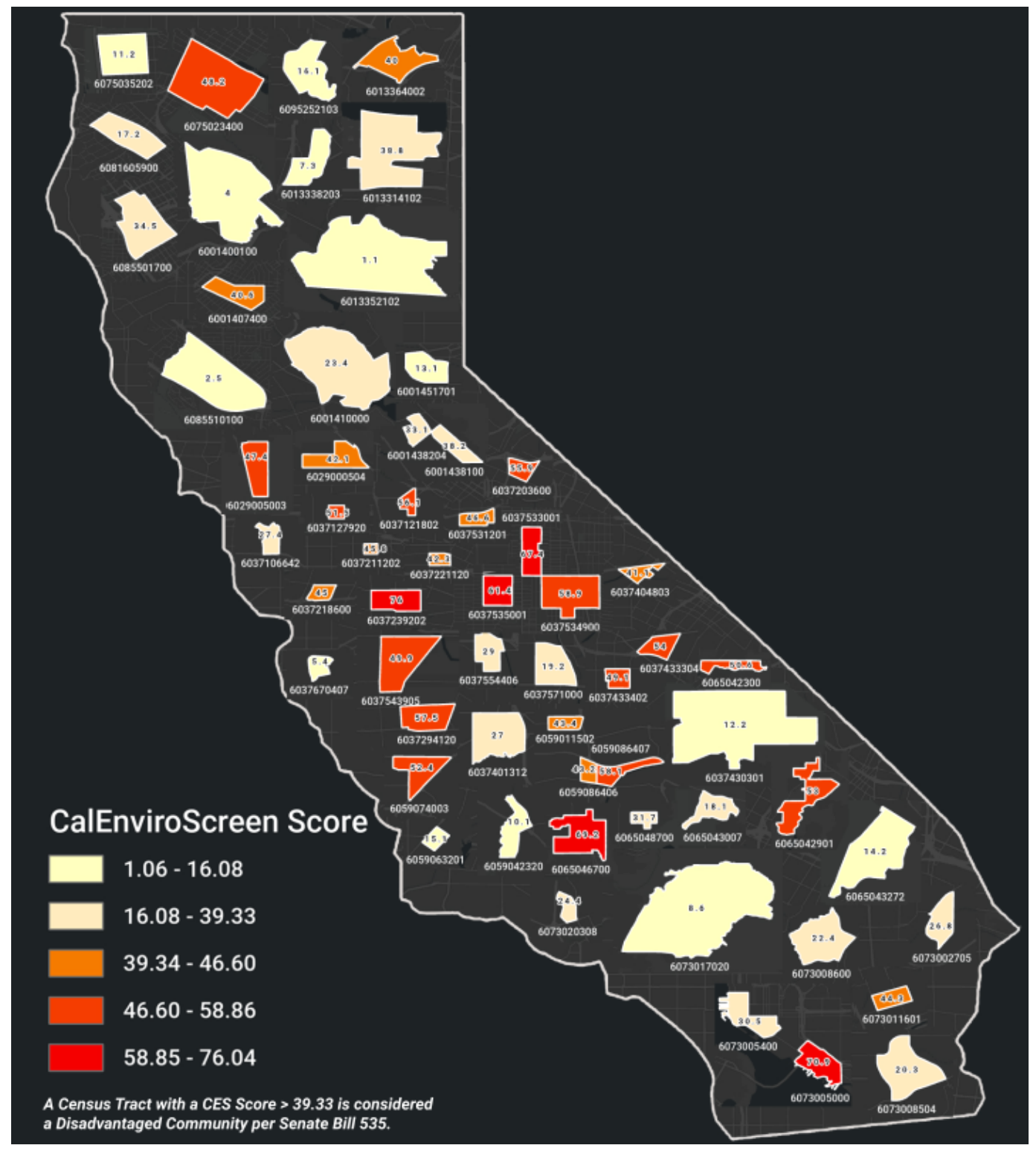


Figure 2. Distribution of Average State of Place Index Across 60 Selected Census Tracts (Higher Score Indicates Higher Inclusion of Microscale Features that Support Safe, Comfortable, Convenient, and Pleasurable Walking and Biking)

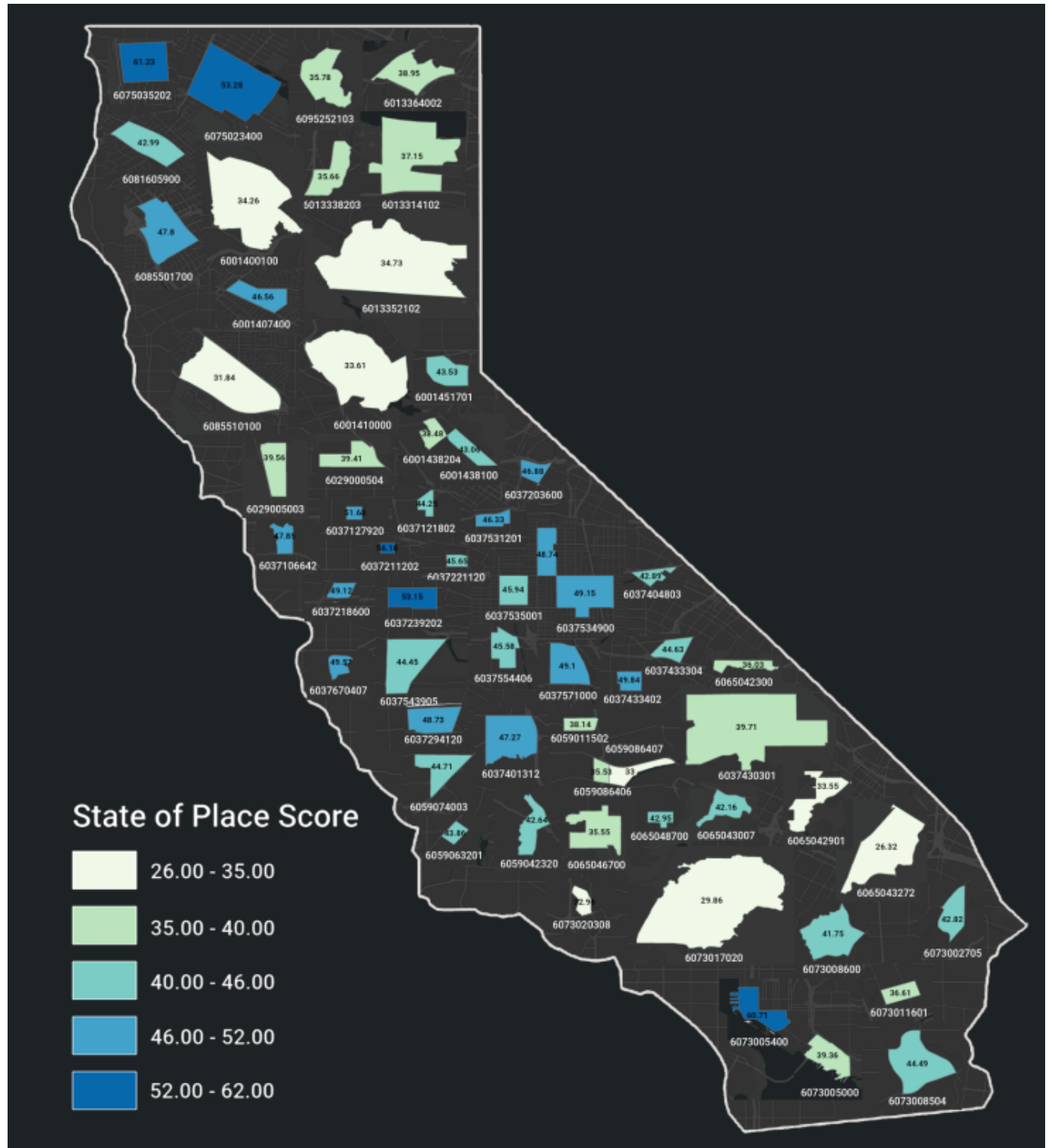


Figure 3. Distribution of Average Annual Household VMT Across 60 Selected Census Tracts

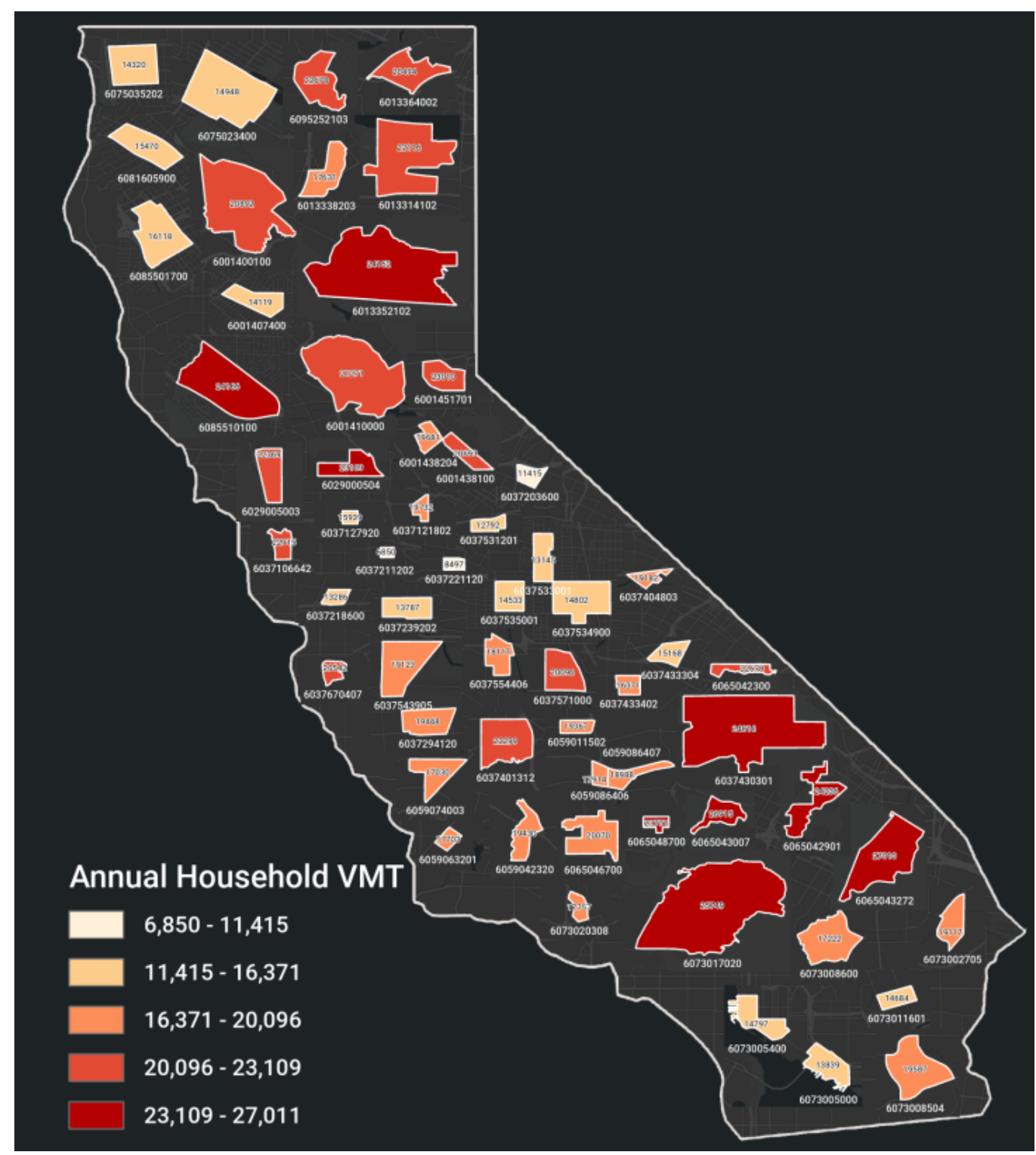


Figure 4. Distribution of Average Annual Household Income Across 60 Selected Census Tracts

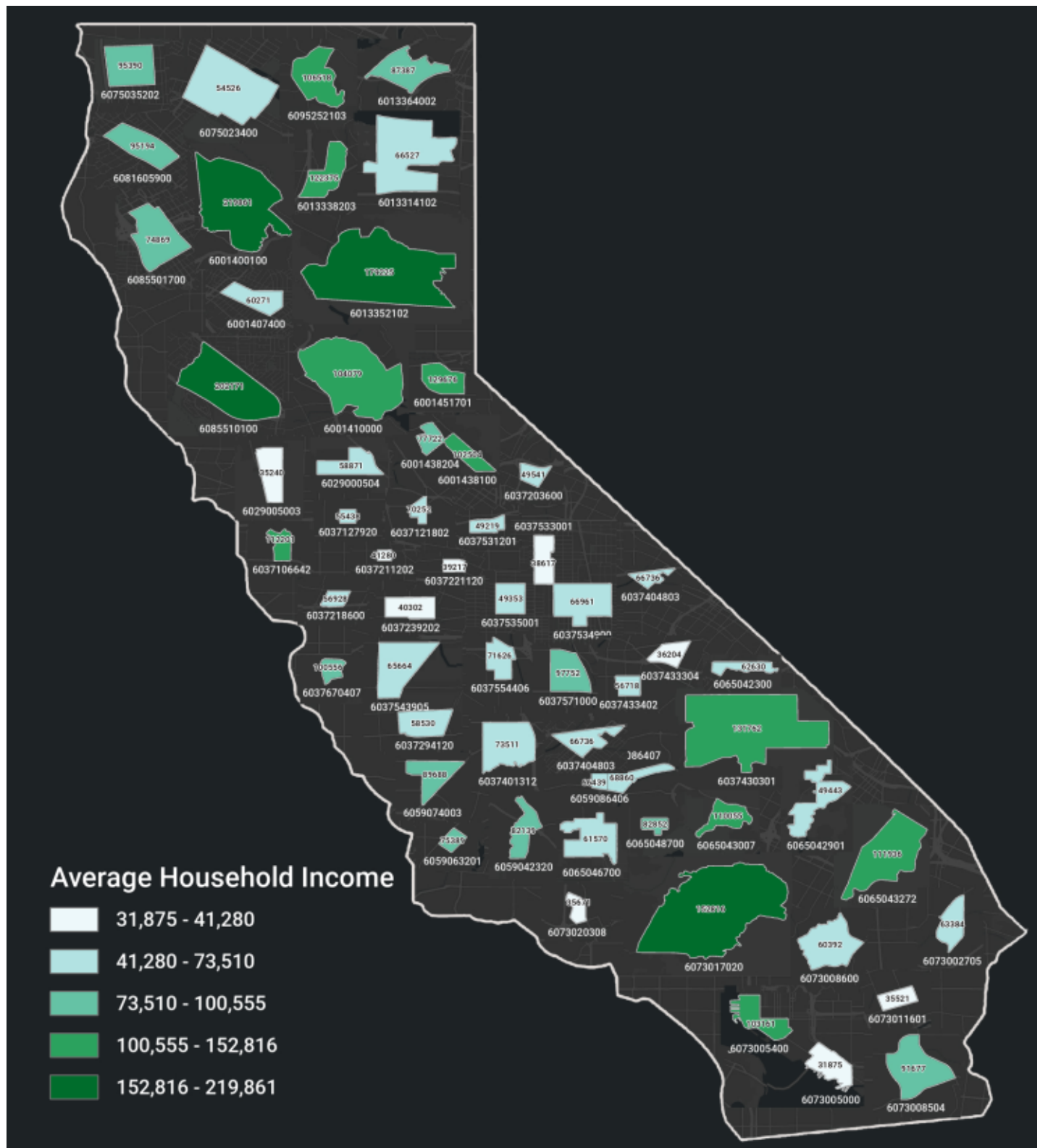


Figure 5. Distribution of Sprawl Index Across 60 Selected Census Tracts (Higher Score Indicates Less Sprawl)

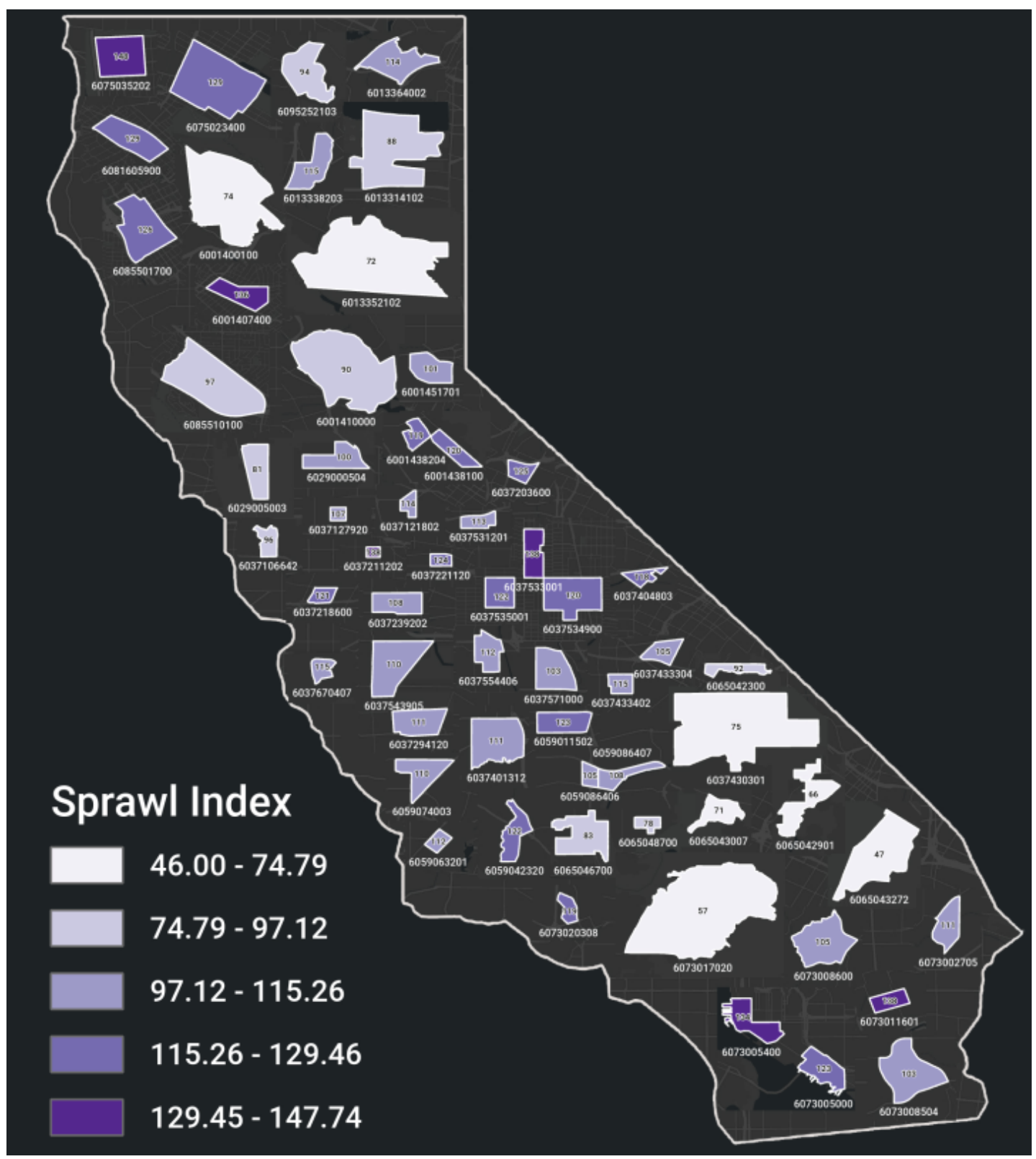




\subsection{Descriptive Statistics of Sample}

Table 5 shows the descriptive statistics for all study variables, revealing a broad continuum of variability across all key factors.

Table 5. Study Descriptive Analysis

\begin{tabular}{|l|l|l|l|l|l|}
\hline & N & Minimum & Maximum & Mean & $\begin{array}{l}\text { Std. } \\
\text { Deviation }\end{array}$ \\
\hline $\begin{array}{l}\text { Annual Vehicle Miles } \\
\text { Traveled per Household for } \\
\text { the Regional Typical } \\
\text { Household }\end{array}$ & 9313 & 6850 & 27039 & 20273.71 & 4175.33 \\
\hline $\begin{array}{l}\text { CES - CalEnviroScreen } \\
\text { Score, Pollution Score } \\
\text { multiplied by Population } \\
\text { Characteristics Score - Tract }\end{array}$ & 9314 & 1.06 & 76.043426 & 33.02 & 19.47 \\
\hline $\begin{array}{l}\text { Households with 0 vehicle } \\
\text { available (Percent) }\end{array}$ & 9314 & 0.0037 & 0.30 & 0.07 & 0.06 \\
\hline $\begin{array}{l}\text { ACS Median Income } \\
\text { Seriod }\end{array}$ & 9177 & 25135.00 & 219861.00 & 87381.00 & 43164.46 \\
\hline SoPIndex & 9314 & -72.83 & 66.93 & -16.67 & 17.03 \\
\hline Sprawl Index & 9314 & 46.98 & 147.74 & 99.21 & 24.43 \\
\hline $\begin{array}{l}\text { Aggregate frequency of transit } \\
\text { service within 0.25 miles of } \\
\text { block group boundary per } \\
\text { pour during evening peak }\end{array}$ & 9314 & 0.00 & 600.67 & 82.85 & 114.66 \\
\hline Valid N (listwise) & 9177 & & & & \\
\hline
\end{tabular}




\section{Disadvantaged Communities}

As previously mentioned, we employed a stratified random sampling technique to select 60 census tracts throughout northern and southern California that varied along a continuum of "vulnerability" as measured by the CalEnviroScreen (CES) tool. Table 6 shows the number of census tracts chosen from each of the strata that were identified. The average CES score for all 60 census tracts was $33.1(19.5 \mathrm{SD})$.

Table 6. Census Tract Selection

\begin{tabular}{|l|l|l|l|l|l|l|l|l|}
\hline \multicolumn{7}{|l|}{ Advantaged } & Disadvantaged \\
\hline $\begin{array}{l}\text { CES 3.0 } \\
\text { Score }\end{array}$ & $\begin{array}{l}0.981- \\
11.254\end{array}$ & $\begin{array}{l}11.255- \\
27.284\end{array}$ & $\begin{array}{l}27.285- \\
39.340\end{array}$ & $\begin{array}{l}39.341- \\
43.315\end{array}$ & $43.316-59.346$ & $59.347-75.377$ & $\begin{array}{l}75.378- \\
80.727\end{array}$ \\
\hline Records & 1002 & 2319 & 1170 & 302 & 893 & 204 & 7 \\
\hline & $\begin{array}{l}30 \text { records to be taken from the Advantaged and Disadvantaged classification each, as } \\
\text { percent of total }\end{array}$ & 0.26 & 0.21 & 0.64 & 0.15 & 0.00 \\
\hline $\begin{array}{l}\text { Records \% } \\
\text { of Category } \\
\text { Total }\end{array}$ & 0.22 & 0.52 & 0.26 & & & 0.15 \\
\hline $\begin{array}{l}\text { \% of Total x } \\
\text { 30 Samples }\end{array}$ & 6.69 & 15.49 & 7.82 & 6.44 & 19.05 & 4.35 & 5 & \\
\hline Samples & 7 & 15 & 8 & 6 & 19 & 5 & \\
\hline
\end{tabular}

Each census tract's CES score was dichotomously coded (where 0 was considered disadvantaged and 1 was considered advantaged) based on whether they were above or below the CES threshold for vulnerability, with vulnerability defined by a CES score of 39.34 or above. Independent Samples T-tests were run to test for differences between disadvantaged and advantaged places with respect to VMT, macro- and micro-level built environment factors, transit access, household income, and vehicle access.

Table 7 shows the means and standard deviations for each variable and shows the results of the ttests.

As expected (and delineated in Hypothesis 1), overall, disadvantaged communities had significantly lower VMT than did advantaged communities, scored significantly lower on the State of Place Index (i.e., quality microscale built environment features at the street level), were significantly less sprawled, had significantly higher access to transit, had significantly higher percentage of households with no vehicle access, and had significantly lower median household incomes. 
Table 7. Descriptive Statistics for Each Study Variable Comparing Disadvantaged vs. Advantaged Communities

\begin{tabular}{|l|l|l|l|l|l|}
\hline & $\begin{array}{l}\text { Disadvantaged } \\
\text { Dichotomous }\end{array}$ & N & Mean & $\begin{array}{l}\text { Std. } \\
\text { Deviation }\end{array}$ & $\begin{array}{l}\text { Std. Error } \\
\text { Mean }\end{array}$ \\
\hline $\begin{array}{l}\text { Annual VMT per } \\
\text { household for the } \\
\text { regional typical } \\
\text { household }\end{array}$ & Disadvantaged & 3931 & 18347.47 & 4014.77 & 64.03 \\
\cline { 2 - 6 } & Advantaged & 5382 & 21680.63 & 3702.25 & 50.47 \\
\hline $\begin{array}{l}\text { Households with 0 } \\
\text { vehicle available (Percent) }\end{array}$ & Disadvantaged & 3931 & .096 & .059 & .00094 \\
\cline { 2 - 6 } & Advantaged & 5383 & .044 & .040 & .00054 \\
\hline \multirow{2}{*}{\begin{tabular}{l} 
ACS Median Income \\
\cline { 2 - 6 }
\end{tabular}} & Disadvantaged & 3889 & 59035.41 & 22329.25 & 357.90 \\
\cline { 2 - 6 } & Advantaged & 5288 & 108227.41 & 42914.73 & 590.15 \\
\hline \multirow{2}{*}{$\begin{array}{l}\text { SoPIndex } \\
\text { Aniles of block group } \\
\text { boundary per hour during } \\
\text { evening peak period }\end{array}$} & Advantaged & 5383 & 42.94 & 68.56 & .934 \\
\cline { 2 - 6 } & Advantaged & 5383 & -17.48 & 17.24 & .235 \\
\hline & Advantaged & 5383 & 93.69 & 25.92 & .353 \\
\hline \multirow{2}{*}{$\begin{array}{l}\text { Sprawl Index } \\
\text { transit service within 0.25 }\end{array}$} & Disadvantaged & 3931 & 137.51 & 139.81 & 2.23 \\
\hline
\end{tabular}


Table 8. Independent Samples T-tests Comparing Disadvantaged vs. Advantaged Communities across Study Variables

\begin{tabular}{|c|c|c|c|c|c|c|c|c|c|c|}
\hline & \multicolumn{2}{|c|}{$\begin{array}{l}\text { Levene's Test for } \\
\text { Equality of } \\
\text { Variances }\end{array}$} & \multicolumn{7}{|c|}{ t-test for Equality of Means } \\
\hline & & \multirow[t]{2}{*}{$\mathrm{F}$} & \multirow[t]{2}{*}{ Sig. } & \multirow[t]{2}{*}{$\mathrm{T}$} & \multirow[t]{2}{*}{$\mathrm{df}$} & \multirow[t]{2}{*}{$\begin{array}{l}\text { Sig. (2- } \\
\text { tailed) }\end{array}$} & \multirow[t]{2}{*}{$\begin{array}{l}\text { Mean } \\
\text { Difference }\end{array}$} & \multirow[t]{2}{*}{$\begin{array}{l}\text { Std. Error } \\
\text { Difference }\end{array}$} & \multicolumn{2}{|c|}{$\begin{array}{l}95 \% \text { Confidence Interval } \\
\text { of the Difference }\end{array}$} \\
\hline & & & & & & & & & Lower & Upper \\
\hline \multirow{2}{*}{$\begin{array}{l}\text { Annual } \\
\text { VMT per } \\
\text { household } \\
\text { for the } \\
\text { regional } \\
\text { typical } \\
\text { household }\end{array}$} & $\begin{array}{l}\text { Equal } \\
\text { variances } \\
\text { assumed }\end{array}$ & 63.34 & 0.000 & -41.40 & 9311 & 0.00 & -3333.16 & 80.51 & -3490.98 & -3175.35 \\
\hline & $\begin{array}{l}\text { Equal } \\
\text { variances not } \\
\text { assumed }\end{array}$ & & & -40.89 & 8057.75 & 0.00 & -3333.16 & 81.53 & -3492.98 & -3173.34 \\
\hline \multirow{2}{*}{$\begin{array}{l}\text { Households } \\
\text { with } 0 \\
\text { vehicle } \\
\text { available } \\
\text { (Percent) }\end{array}$} & $\begin{array}{l}\text { Equal } \\
\text { variances } \\
\text { assumed }\end{array}$ & 1256.83 & 0.000 & 50.77 & 9312 & 0.00 & 0.052 & 0.001 & 0.050 & 0.054 \\
\hline & $\begin{array}{l}\text { Equal } \\
\text { variances not } \\
\text { assumed }\end{array}$ & & & 47.90 & 6458.60 & 0.00 & 0.052 & 0.001 & 0.050 & 0.054 \\
\hline \multirow[t]{2}{*}{$\begin{array}{l}\text { ACS } \\
\text { Median } \\
\text { Income }\end{array}$} & $\begin{array}{l}\text { Equal } \\
\text { variances } \\
\text { assumed }\end{array}$ & 694.42 & 0.000 & -65.29 & 9175 & 0.00 & -49191.99 & 753.51 & -50669.04 & -47714.95 \\
\hline & $\begin{array}{l}\text { Equal } \\
\text { variances not } \\
\text { assumed }\end{array}$ & & & -71.27 & 8354.44 & 0.00 & -49191.99 & 690.19 & -50544.94 & -47839.04 \\
\hline SoP Index & $\begin{array}{l}\text { Equal } \\
\text { variances } \\
\text { assumed }\end{array}$ & 4.81 & 0.028 & 5.42 & 9312 & 0.00 & 1.93 & 0.36 & 1.23 & 2.63 \\
\hline
\end{tabular}




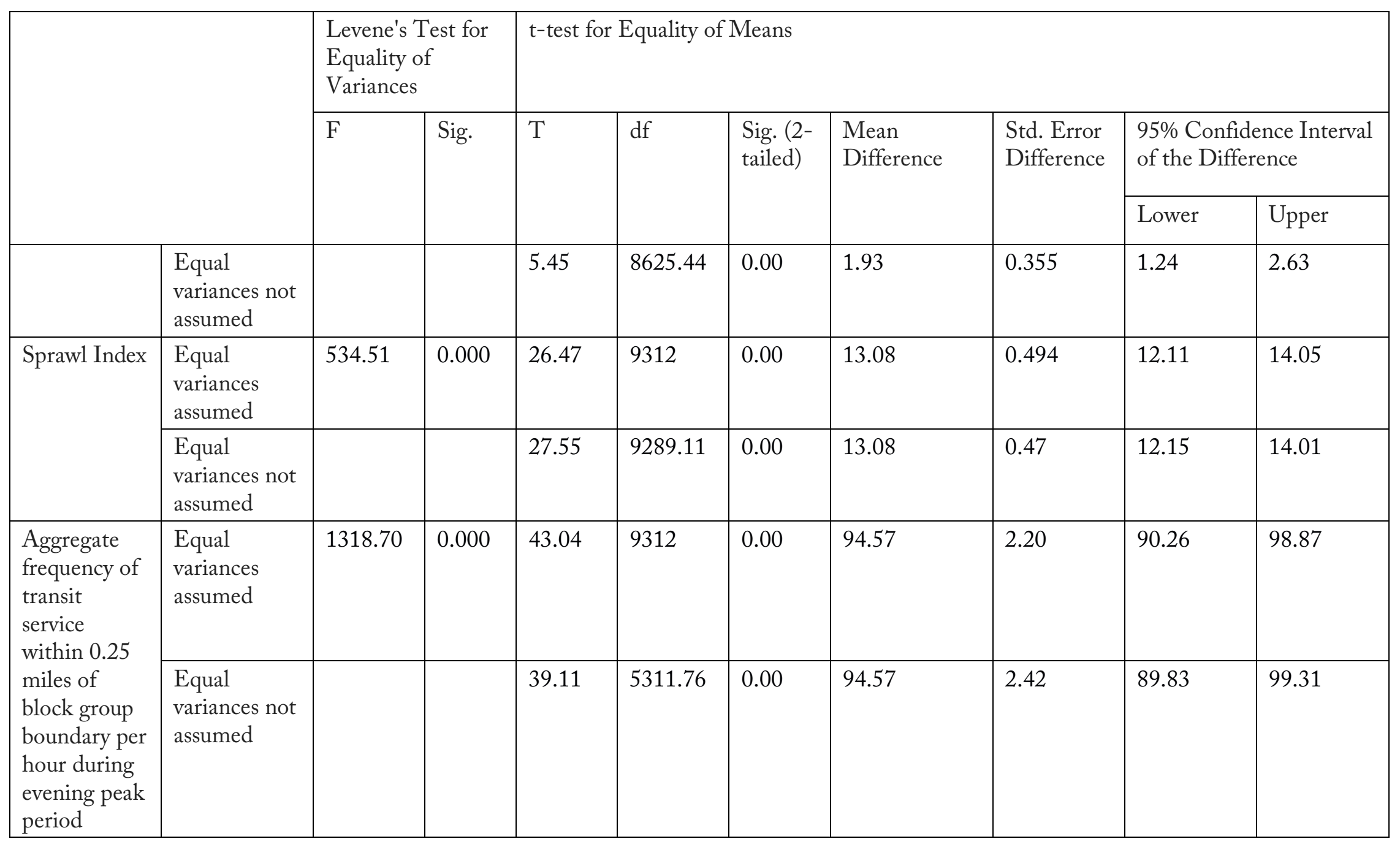




\section{Macro and Micro Built Environment and VMT}

To test Hypothesis 2, we ran a stepwise multiple linear regression analysis to model the impact of macroscale built environment features on VMT and the moderating effect of micro-level built environment features, while controlling for income, vehicle access, and transit access. The first model we specified using our original conceptual framework generated an unexpected outcomethat microscale built environments were tied to higher VMT. As this finding did not align with the prevailing urban design and travel literature, we began to test for further interactive effects between our variables. We posited there could be interactions between not only macro-level built environment features (i.e., the Sprawl Index) and micro-level built environment features (i.e., the State of Place Index), but also interactions between: State of Place and income; Sprawl, State of Place and income; State of Place and transit access; and Sprawl, State of Place, income, and transit. We mean centered all variables included in any interaction term, to mitigate against multicollinearity. We then ran a further stepwise multiple linear regression model, which confirmed that all five potential interaction terms were significantly related to VMT and specified the coefficient on the State of Place Index in the direction supportive of existing research.

Table 9 shows the results of these models. All variables in the model were significantly related to VMT. Lower VMT values were significantly tied to more compact places, areas with a higher State of Place Index, communities with good access to transit, lower incomes, and a higher percentage of households without access to vehicles. 
Table 9. Stepwise Multiple Regression Model for VMT

\begin{tabular}{|c|c|c|c|c|c|c|c|c|}
\hline \multicolumn{9}{|c|}{ Coefficients $^{a}$} \\
\hline \multicolumn{2}{|c|}{ Model } & \multicolumn{2}{|c|}{ Unstandardized Coefficients } & \multirow{2}{*}{$\begin{array}{l}\text { Standardized } \\
\text { Coefficients }\end{array}$} & \multirow[t]{2}{*}{$\mathrm{t}$} & \multirow[t]{2}{*}{ Sig. } & \multicolumn{2}{|c|}{ Collinearity Statistics } \\
\hline & & $\mathrm{B}$ & Std. Error & & & & Tolerance & VIF \\
\hline \multirow[t]{2}{*}{1} & (Constant) & 20272.54 & 40.70 & & 498.09 & 0.000 & & \\
\hline & SoP Centered & -87.93 & 2.39 & -0.36 & -36.77 & 0.000 & 1.000 & 1.00 \\
\hline \multirow[t]{3}{*}{2} & (Constant) & 20267.88 & 24.34 & & 832.71 & 0.000 & & \\
\hline & SoP Centered & -2.80 & 1.58 & -0.011 & -1.78 & 0.076 & 0.823 & 1.22 \\
\hline & Sprawl Centered & -140.34 & 1.09 & -0.825 & -128.38 & 0.000 & 0.823 & 1.22 \\
\hline \multirow[t]{4}{*}{3} & (Constant) & 20409.86 & 26.00 & & 785.11 & 0.000 & & \\
\hline & SoP Centered & 1.64 & 1.59 & 0.007 & 1.03 & 0.303 & 0.792 & 1.26 \\
\hline & Sprawl Centered & -158.73 & 1.67 & -0.933 & -95.09 & 0.000 & 0.345 & 2.90 \\
\hline & $\begin{array}{l}\text { INTSoP X Sprawl } \\
\text { Centered }\end{array}$ & -0.810 & 0.056 & -0.132 & -14.45 & 0.000 & 0.401 & 2.49 \\
\hline \multirow[t]{4}{*}{4} & (Constant) & 21066.49 & 27.67 & & 761.33 & 0.000 & & \\
\hline & SoP Centered & 2.21 & 1.44 & 0.009 & 1.53 & 0.125 & 0.792 & 1.26 \\
\hline & Sprawl Centered & -153.81 & 1.51 & -0.904 & -101.56 & 0.000 & 0.343 & 2.91 \\
\hline & $\begin{array}{l}\text { INTSoP X Sprawl } \\
\text { Centered }\end{array}$ & -0.408 & 0.051 & -0.066 & -7.93 & 0.000 & 0.389 & 2.57 \\
\hline
\end{tabular}




\begin{tabular}{|c|c|c|c|c|c|c|c|c|}
\hline \multicolumn{9}{|c|}{ Coefficients $^{a}$} \\
\hline \multirow{2}{*}{\multicolumn{2}{|c|}{ Model }} & \multicolumn{2}{|c|}{ Unstandardized Coefficients } & \multirow{3}{*}{$\begin{array}{l}\begin{array}{l}\text { Standardized } \\
\text { Coefficients }\end{array} \\
\text { Beta } \\
-0.240\end{array}$} & \multirow{3}{*}{$\begin{array}{l}t \\
-45.06\end{array}$} & \multirow{3}{*}{$\begin{array}{l}\text { Sig. } \\
0.000\end{array}$} & \multicolumn{2}{|c|}{ Collinearity Statistics } \\
\hline & & \multirow{2}{*}{$\begin{array}{l}\mathrm{B} \\
-8.69\end{array}$} & \multirow{2}{*}{$\begin{array}{l}\text { Std. Error } \\
0.193\end{array}$} & & & & Tolerance & VIF \\
\hline & $\begin{array}{l}\text { Aggregate frequency } \\
\text { of transit service } \\
\text { within } 0.25 \text { miles of } \\
\text { block group boundary } \\
\text { per hour during } \\
\text { evening peak period }\end{array}$ & & & & & & 0.961 & 1.04 \\
\hline \multirow[t]{6}{*}{5} & (Constant) & 21245.43 & 31.40 & & 676.63 & 0.000 & & \\
\hline & SoP Centered & 3.85 & 1.43 & 0.016 & 2.68 & 0.007 & 0.785 & 1.27 \\
\hline & Sprawl Centered & -150.98 & 1.52 & -0.887 & -99.17 & 0.000 & 0.335 & 2.99 \\
\hline & $\begin{array}{l}\text { INTSoP X Sprawl } \\
\text { Centered }\end{array}$ & -0.355 & 0.051 & -0.058 & -6.93 & 0.000 & 0.386 & 2.59 \\
\hline & $\begin{array}{l}\text { Aggregate frequency } \\
\text { of transit service } \\
\text { within } 0.25 \text { miles of } \\
\text { block group boundary } \\
\text { per hour during } \\
\text { evening peak period }\end{array}$ & -10.95 & 0.271 & -0.302 & -40.36 & 0.000 & 0.478 & 2.09 \\
\hline & $\begin{array}{l}\text { INTSoP X Transit } \\
\text { Centered }\end{array}$ & -0.132 & 0.011 & -0.088 & -11.76 & 0.000 & 0.474 & 2.11 \\
\hline \multirow[t]{2}{*}{6} & (Constant) & 20340.83 & 64.12 & & 317.24 & 0.000 & & \\
\hline & SoP Centered & 3.46 & 1.41 & 0.014 & 2.44 & 0.015 & 0.785 & 1.28 \\
\hline
\end{tabular}




\begin{tabular}{|c|c|c|c|c|c|c|c|c|}
\hline \multicolumn{9}{|c|}{ Coefficients $^{a}$} \\
\hline \multirow{2}{*}{\multicolumn{2}{|c|}{ Model }} & \multicolumn{2}{|c|}{ Unstandardized Coefficients } & \multirow{2}{*}{$\begin{array}{l}\text { Standardized } \\
\text { Coefficients }\end{array}$} & \multirow[t]{2}{*}{$\mathrm{t}$} & \multirow[t]{2}{*}{ Sig. } & \multicolumn{2}{|c|}{ Collinearity Statistics } \\
\hline & & \multirow{2}{*}{$\begin{array}{l}\mathrm{B} \\
-144.31\end{array}$} & \multirow{2}{*}{$\begin{array}{l}\text { Std. Error } \\
1.56\end{array}$} & & & & \multirow{2}{*}{$\begin{array}{l}\text { Tolerance } \\
0.311\end{array}$} & \multirow{2}{*}{$\begin{array}{l}\text { VIF } \\
3.21\end{array}$} \\
\hline & Sprawl Centered & & & -0.848 & -92.68 & 0.000 & & \\
\hline & $\begin{array}{l}\text { INTSoP X Sprawl } \\
\text { Centered }\end{array}$ & -0.431 & 0.051 & -0.070 & -8.48 & 0.000 & 0.383 & 2.61 \\
\hline & $\begin{array}{l}\text { Aggregate frequency } \\
\text { of transit service } \\
\text { within } 0.25 \text { miles of } \\
\text { block group boundary } \\
\text { per hour during } \\
\text { evening peak period }\end{array}$ & -10.11 & 0.273 & -0.279 & -37.07 & 0.000 & 0.461 & 2.17 \\
\hline & $\begin{array}{l}\text { INTSoP X Transit } \\
\text { Centered }\end{array}$ & -0.161 & 0.011 & -0.108 & -14.36 & 0.000 & 0.461 & 2.17 \\
\hline & ACS Median Income & 0.010 & 0.001 & 0.100 & 16.11 & 0.000 & 0.674 & 1.48 \\
\hline \multirow[t]{4}{*}{7} & (Constant) & 19252.87 & 89.20 & & 215.84 & 0.000 & & \\
\hline & SoP Centered & 2.67 & 1.39 & 0.011 & 1.92 & 0.055 & 0.784 & 1.28 \\
\hline & Sprawl Centered & -139.63 & 1.56 & -0.821 & -89.71 & 0.000 & 0.302 & 3.31 \\
\hline & $\begin{array}{l}\text { INTSoP X Sprawl } \\
\text { Centered }\end{array}$ & -0.115 & 0.053 & -0.019 & -2.16 & 0.031 & 0.338 & 2.96 \\
\hline
\end{tabular}




\begin{tabular}{|c|c|c|c|c|c|c|c|c|}
\hline \multicolumn{9}{|c|}{ Coefficients $^{a}$} \\
\hline \multirow{2}{*}{\multicolumn{2}{|c|}{ Model }} & \multicolumn{2}{|c|}{ Unstandardized Coefficients } & \multirow{3}{*}{$\begin{array}{l}\begin{array}{l}\text { Standardized } \\
\text { Coefficients }\end{array} \\
\text { Beta } \\
-0.262\end{array}$} & \multirow{3}{*}{$\begin{array}{l}\mathrm{t} \\
-35.08\end{array}$} & \multirow{3}{*}{$\begin{array}{l}\text { Sig. } \\
0.000\end{array}$} & \multicolumn{2}{|c|}{ Collinearity Statistics } \\
\hline & & \multirow{2}{*}{$\begin{array}{l}\mathrm{B} \\
-9.50\end{array}$} & \multirow{2}{*}{$\begin{array}{l}\text { Std. Error } \\
0.271\end{array}$} & & & & \multirow{2}{*}{$\begin{array}{l}\text { Tolerance } \\
0.453\end{array}$} & \multirow{2}{*}{$\begin{array}{l}\text { VIF } \\
2.21\end{array}$} \\
\hline & $\begin{array}{l}\text { Aggregate frequency } \\
\text { of transit service } \\
\text { within } 0.25 \text { miles of } \\
\text { block group boundary } \\
\text { per hour during } \\
\text { evening peak period }\end{array}$ & & & & & & & \\
\hline & $\begin{array}{l}\text { INTSoP X Transit } \\
\text { Centered }\end{array}$ & -0.110 & 0.011 & -0.074 & -9.60 & 0.000 & 0.430 & 2.32 \\
\hline & ACS Median Income & 0.022 & 0.001 & 0.224 & 23.75 & 0.000 & 0.283 & 3.53 \\
\hline & $\begin{array}{l}\text { INTSoP X Income } \\
\text { Centered }\end{array}$ & 0.001 & 0.000 & 0.165 & 17.26 & 0.000 & 0.277 & 3.61 \\
\hline \multirow[t]{4}{*}{8} & (Constant) & 19357.52 & 85.17 & & 227.27 & 0.000 & & \\
\hline & SoP Centered & -13.69 & 1.44 & -0.056 & -9.54 & 0.000 & 0.671 & 1.49 \\
\hline & Sprawl Centered & -135.30 & 1.49 & -0.795 & -90.69 & 0.000 & 0.299 & 3.35 \\
\hline & $\begin{array}{l}\text { INTSoP X Sprawl } \\
\text { Centered }\end{array}$ & 0.158 & 0.052 & 0.026 & 3.05 & 0.002 & 0.327 & 3.06 \\
\hline
\end{tabular}




\begin{tabular}{|c|c|c|c|c|c|c|c|c|}
\hline \multicolumn{9}{|c|}{ Coefficients $^{a}$} \\
\hline \multirow{2}{*}{\multicolumn{2}{|c|}{ Model }} & \multicolumn{2}{|c|}{ Unstandardized Coefficients } & \multirow{3}{*}{$\begin{array}{l}\text { Standardized } \\
\text { Coefficients } \\
\text { Beta } \\
-0.263\end{array}$} & \multirow{3}{*}{$\begin{array}{l}\mathrm{t} \\
-36.87 \\
\end{array}$} & \multirow{3}{*}{$\begin{array}{l}\text { Sig. } \\
0.000 \\
\end{array}$} & \multicolumn{2}{|c|}{ Collinearity Statistics } \\
\hline & & \multirow{2}{*}{$\begin{array}{l}\text { B } \\
-9.52\end{array}$} & \multirow{2}{*}{$\begin{array}{l}\text { Std. Error } \\
0.258\end{array}$} & & & & \multirow{2}{*}{$\begin{array}{l}\text { Tolerance } \\
0.453\end{array}$} & \multirow{2}{*}{$\begin{array}{l}\text { VIF } \\
2.21\end{array}$} \\
\hline & $\begin{array}{l}\text { Aggregate frequency } \\
\text { of transit service } \\
\text { within } 0.25 \text { miles of } \\
\text { block group boundary } \\
\text { per hour during } \\
\text { evening peak period }\end{array}$ & & & & & & & \\
\hline & $\begin{array}{l}\text { INTSoP X Transit } \\
\text { Centered }\end{array}$ & -0.066 & 0.011 & -0.044 & -5.99 & 0.000 & 0.423 & 2.37 \\
\hline & ACS Median Income & 0.023 & 0.001 & 0.236 & 26.21 & 0.000 & 0.283 & 3.54 \\
\hline & $\begin{array}{l}\text { INTSoP X Income } \\
\text { Centered }\end{array}$ & 0.000 & 0.000 & 0.086 & 9.03 & 0.000 & 0.255 & 3.92 \\
\hline & $\begin{array}{l}\text { INTSoPX Sprawl } \\
\text { Centered X Income } \\
\text { Centered }\end{array}$ & $-2.84 \mathrm{E}-05$ & 0.000 & -0.196 & -30.09 & 0.000 & 0.539 & 1.86 \\
\hline \multirow[t]{5}{*}{9} & (Constant) & 19339.25 & 85.003 & & 227.513 & 0.000 & & \\
\hline & SoP Centered & -13.15 & 1.43 & -0.054 & -9.17 & 0.000 & 0.669 & 1.49 \\
\hline & Sprawl Centered & -134.31 & 1.50 & -0.789 & -89.83 & 0.000 & 0.296 & 3.38 \\
\hline & $\begin{array}{l}\text { INTSoP X Sprawl } \\
\text { Centered }\end{array}$ & 0.181 & 0.052 & 0.029 & 3.50 & 0.000 & 0.326 & 3.07 \\
\hline & $\begin{array}{l}\text { Aggregate frequency } \\
\text { of transit service }\end{array}$ & -9.76 & 0.260 & -0.269 & -37.55 & 0.000 & 0.445 & 2.25 \\
\hline
\end{tabular}




\begin{tabular}{|c|c|c|c|c|c|c|c|c|}
\hline \multicolumn{9}{|c|}{ Coefficients $^{a}$} \\
\hline \multirow{2}{*}{\multicolumn{2}{|c|}{ Model }} & \multicolumn{2}{|c|}{ Unstandardized Coefficients } & \multirow{2}{*}{$\begin{array}{l}\begin{array}{l}\text { Standardized } \\
\text { Coefficients }\end{array} \\
\text { Beta }\end{array}$} & \multirow[t]{2}{*}{$\mathrm{t}$} & \multirow[t]{2}{*}{ Sig. } & \multicolumn{2}{|c|}{ Collinearity Statistics } \\
\hline & & \multirow[t]{2}{*}{$\mathrm{B}$} & \multirow[t]{2}{*}{ Std. Error } & & & & \multirow[t]{2}{*}{ Tolerance } & \multirow[t]{2}{*}{ VIF } \\
\hline & $\begin{array}{l}\text { within } 0.25 \text { miles of } \\
\text { block group boundary } \\
\text { per hour during } \\
\text { evening peak period }\end{array}$ & & & & & & & \\
\hline & $\begin{array}{l}\text { INTSoPX Transit } \\
\text { Centered }\end{array}$ & -0.054 & 0.011 & -0.036 & -4.86 & 0.000 & 0.412 & 2.43 \\
\hline & ACS Median Income & 0.023 & 0.001 & 0.237 & 26.36 & 0.000 & 0.283 & 3.54 \\
\hline & $\begin{array}{l}\text { INTSoPX Income } \\
\text { Centered }\end{array}$ & 0.000 & 0.000 & 0.099 & 10.22 & 0.000 & 0.246 & 4.07 \\
\hline & $\begin{array}{l}\text { INTSoP X Sprawl } \\
\text { Centered X Income } \\
\text { Centered }\end{array}$ & $-2.80 \mathrm{E}-05$ & 0.000 & -0.193 & -29.57 & 0.000 & 0.536 & 1.87 \\
\hline & $\begin{array}{l}\text { INTSoP X Sprawl } \\
\text { Centered X Income } \\
\text { Centered X Transit } \\
\text { Centered }\end{array}$ & $-4.47 \mathrm{E}-08$ & 0.000 & -0.037 & -6.86 & 0.000 & 0.801 & 1.25 \\
\hline \multirow[t]{4}{*}{10} & (Constant) & 20053.35 & 120.66 & & 166.20 & 0.000 & & \\
\hline & SoP Centered & -13.50 & 1.430 & -0.055 & -9.44 & 0.000 & 0.668 & 1.50 \\
\hline & Sprawl Centered & -132.58 & 1.65 & -0.779 & -80.47 & 0.000 & 0.242 & 4.13 \\
\hline & $\begin{array}{l}\text { INTSoP X Sprawl } \\
\text { Centered }\end{array}$ & 0.152 & 0.054 & 0.025 & 2.82 & 0.005 & 0.296 & 3.38 \\
\hline
\end{tabular}




\begin{tabular}{|c|c|c|c|c|c|c|c|c|}
\hline \multicolumn{9}{|c|}{ Coefficients $^{a}$} \\
\hline \multirow{2}{*}{\multicolumn{2}{|c|}{ Model }} & \multicolumn{2}{|c|}{ Unstandardized Coefficients } & \multirow{2}{*}{$\begin{array}{l}\text { Standardized } \\
\text { Coefficients } \\
\text { Beta }\end{array}$} & \multirow[t]{2}{*}{$\mathrm{t}$} & \multirow[t]{2}{*}{ Sig. } & \multicolumn{2}{|c|}{ Collinearity Statistics } \\
\hline & & \multirow{2}{*}{$\begin{array}{l}\mathrm{B} \\
-8.79\end{array}$} & \multirow{2}{*}{$\begin{array}{l}\text { Std. Error } \\
0.290\end{array}$} & & & & \multirow{2}{*}{$\begin{array}{l}\text { Tolerance } \\
0.356\end{array}$} & \multirow{2}{*}{$\begin{array}{l}\text { VIF } \\
2.81\end{array}$} \\
\hline & $\begin{array}{l}\text { Aggregate frequency } \\
\text { of transit service } \\
\text { within } 0.25 \text { miles of } \\
\text { block group boundary } \\
\text { per hour during } \\
\text { evening peak period }\end{array}$ & & & -0.242 & -30.35 & 0.000 & & \\
\hline & $\begin{array}{l}\text { INTSoP X Transit } \\
\text { Centered }\end{array}$ & -0.045 & 0.011 & -0.030 & -3.91 & 0.000 & 0.390 & 2.57 \\
\hline & ACS Median Income & 0.020 & 0.001 & 0.203 & 20.12 & 0.000 & 0.223 & 4.48 \\
\hline & $\begin{array}{l}\text { INTSoP X Income } \\
\text { Centered }\end{array}$ & 0.000 & 0.000 & 0.097 & 9.83 & 0.000 & 0.231 & 4.33 \\
\hline & $\begin{array}{l}\text { INTSoP X Sprawl } \\
\text { Centered X Income } \\
\text { Centered }\end{array}$ & $-2.85 \mathrm{E}-05$ & 0.000 & -0.197 & -30.14 & 0.000 & 0.533 & 1.88 \\
\hline & $\begin{array}{l}\text { INTSoP X Sprawl } \\
\text { Centered X Income } \\
\text { Centered X Transit } \\
\text { Centered }\end{array}$ & $-4.31 \mathrm{E}-08$ & 0.000 & -0.035 & -6.64 & 0.000 & 0.800 & 1.25 \\
\hline & $\begin{array}{l}\text { Households with } 0 \\
\text { vehicle available } \\
\text { (Count) }\end{array}$ & -0.527 & 0.222 & -0.014 & -2.38 & 0.017 & 0.619 & 1.62 \\
\hline
\end{tabular}




\begin{tabular}{|c|c|c|c|c|c|c|c|}
\hline \multicolumn{8}{|l|}{ Coefficients $^{a}$} \\
\hline \multirow[t]{2}{*}{ Model } & \multicolumn{2}{|c|}{ Unstandardized Coefficients } & \multirow{2}{*}{$\begin{array}{l}\text { Standardized } \\
\text { Coefficients }\end{array}$} & \multirow[t]{2}{*}{$\mathrm{t}$} & \multirow[t]{2}{*}{ Sig. } & \multicolumn{2}{|c|}{ Collinearity Statistics } \\
\hline & $\mathrm{B}$ & Std. Error & & & & Tolerance & VIF \\
\hline $\begin{array}{l}\text { CES - } \\
\text { CalEnviroScreen } \\
\text { Score, Pollution Score } \\
\text { multiplied by } \\
\text { Population } \\
\text { Characteristics Score } \\
\text { - Tract }\end{array}$ & -13.25 & 1.61 & -0.061 & -8.22 & 0.000 & 0.407 & 2.46 \\
\hline
\end{tabular}

a. Dependent Variable: Annual Vehicle Miles Traveled per Household for the Regional Typical Household 
To better understand the impact of the multiple interaction terms, we ran a series of One-Way analysis of variance (ANOVA) for interaction terms. To do so, we converted each of the four variables included in the interaction terms into dichotomous variables, with 0 indicating a lowerthan-average score on its corresponding variable, and 1 indicating a higher-than-average score on its corresponding variable. Tables 10-18 show the results of the ANOVAs and Tukey's honestly significant difference (HSD) post-hoc analysis, excluding for the post-hoc test for the four-way interaction, as the combination of between groups comparisons would have created a multi-page table. However, this table is available upon request and has been submitted to MTI as an appendix.

Table 10. Sprawl Index x State of Place Index One-Way ANOVA

\begin{tabular}{|c|c|c|c|c|c|}
\hline \multicolumn{6}{|l|}{ ANOVA } \\
\hline \multicolumn{6}{|c|}{ Annual Vehicle Miles Traveled per Household for the Regional Typical Household } \\
\hline & Sum of Squares & Df & Mean Square & $\mathrm{F}$ & Sig. \\
\hline $\begin{array}{l}\text { Between } \\
\text { Groups }\end{array}$ & $8.57 \mathrm{E}+10$ & 3 & $2.86 \mathrm{E}+10$ & $3.47 \mathrm{E}+03$ & 0.000 \\
\hline $\begin{array}{l}\text { Within } \\
\text { Groups }\end{array}$ & $7.67 \mathrm{E}+10$ & 9309 & $8.23 \mathrm{E}+06$ & & \\
\hline Total & $1.62 \mathrm{E}+11$ & 9312 & & & \\
\hline
\end{tabular}

When looking at how macro-level built environment features interacted with micro-level built environment features to impact VMT (controlling for other factors), areas that were compact, with a higher State of Place Index had the lowest levels of VMT. Whereas sprawled areas with a lower State of Place Index had the highest levels of VMT. All four groups significantly differed from one another with respect to associated levels of VMT. 
Table 11. Tukey HSB Post Hoc Test for Sprawl Index x State of Place Index

\begin{tabular}{|c|c|c|c|c|c|c|}
\hline \multicolumn{7}{|c|}{ Multiple Comparisons } \\
\hline \multicolumn{7}{|c|}{ Dependent Variable: } \\
\hline \multicolumn{7}{|c|}{ Tukey HSD } \\
\hline \multirow{2}{*}{\multicolumn{2}{|c|}{ (I) SoP X Sprawl }} & \multirow{2}{*}{$\begin{array}{l}\text { Mean } \\
\text { Difference } \\
\text { (I-J) }\end{array}$} & \multirow{2}{*}{$\begin{array}{l}\text { Std. } \\
\text { Error }\end{array}$} & \multirow[t]{2}{*}{ Sig. } & \multicolumn{2}{|c|}{$95 \%$ Confidence Interval } \\
\hline & & & & & Lower Bound & $\begin{array}{l}\text { Upper } \\
\text { Bound }\end{array}$ \\
\hline \multirow[t]{3}{*}{$\begin{array}{l}\text { Compact, } \\
\text { High SoP }\end{array}$} & $\begin{array}{l}\text { Compact, Low } \\
\text { SoP }\end{array}$ & $-350.873^{*}$ & 80.654 & 0.000 & -558.11 & -143.63 \\
\hline & $\begin{array}{l}\text { Sprawled, High } \\
\text { SoP }\end{array}$ & $-6014.452^{*}$ & 95.942 & 0.000 & -6260.97 & -5767.93 \\
\hline & $\begin{array}{l}\text { Sprawled, Low } \\
\text { SoP }\end{array}$ & $-6388.003^{*}$ & 74.107 & 0.000 & -6578.42 & -6197.58 \\
\hline \multirow[t]{3}{*}{$\begin{array}{l}\text { Compact, } \\
\text { Low SoP }\end{array}$} & $\begin{array}{l}\text { Compact, High } \\
\text { SoP }\end{array}$ & $350.873^{*}$ & 80.654 & 0.000 & 143.63 & 558.11 \\
\hline & $\begin{array}{l}\text { Sprawled, High } \\
\text { SoP }\end{array}$ & $-5663.579^{*}$ & 104.359 & 0.000 & -5931.73 & -5395.43 \\
\hline & $\begin{array}{l}\text { Sprawled, Low } \\
\text { SoP }\end{array}$ & $-6037.130^{*}$ & 84.722 & 0.000 & -6254.82 & -5819.44 \\
\hline \multirow[t]{3}{*}{$\begin{array}{l}\text { Sprawled, } \\
\text { High SoP }\end{array}$} & $\begin{array}{l}\text { Compact, High } \\
\text { SoP }\end{array}$ & $6014.452^{*}$ & 95.942 & 0.000 & 5767.93 & 6260.97 \\
\hline & $\begin{array}{l}\text { Compact, Low } \\
\text { SoP }\end{array}$ & $5663.579^{*}$ & 104.359 & 0.000 & 5395.43 & 5931.73 \\
\hline & $\begin{array}{l}\text { Sprawled, Low } \\
\text { SoP }\end{array}$ & $-373.551^{*}$ & 99.386 & 0.001 & -628.92 & -118.18 \\
\hline \multirow[t]{3}{*}{$\begin{array}{l}\text { Sprawled, } \\
\text { Low SoP }\end{array}$} & $\begin{array}{l}\text { Compact, High } \\
\text { SoP }\end{array}$ & $6388.003^{*}$ & 74.107 & 0.000 & 6197.58 & 6578.42 \\
\hline & $\begin{array}{l}\text { Compact, Low } \\
\text { SoP }\end{array}$ & $6037.130^{*}$ & 84.722 & 0.000 & 5819.44 & 6254.82 \\
\hline & $\begin{array}{l}\text { Sprawled, High } \\
\text { SoP }\end{array}$ & $373.551^{*}$ & 99.386 & 0.001 & 118.18 & 628.92 \\
\hline
\end{tabular}

* The mean difference is significant at the 0.05 level.

When looking at how macroscale built environment features and income interacted to affect VMT, we found that high income areas with a lower State of Place Index had the highest levels of VMT, as compared to low income areas with a higher State of Place Index, which had the lowest levels of VMT. All combinations between the four groups significantly differed from one another with respect to associated levels of VMT. 
Table 12. State of Place Index x Income One-way ANOVA

\begin{tabular}{|l|l|l|l|l|l|}
\hline ANOVA \\
\hline \\
\hline
\end{tabular}


Table 13. Tukey HSB Post Hoc Test for State of Place Index x Income

\begin{tabular}{|c|c|c|c|c|c|c|}
\hline \multicolumn{7}{|c|}{ Multiple Comparisons } \\
\hline \multicolumn{7}{|c|}{ Dependent Variable: } \\
\hline \multicolumn{7}{|l|}{ Tukey HSD } \\
\hline \multirow{2}{*}{\multicolumn{2}{|c|}{ (I) SoP X Income }} & \multirow[t]{2}{*}{$\begin{array}{l}\text { Mean } \\
\text { Difference (I-J) }\end{array}$} & \multirow[t]{2}{*}{ Std. Error } & \multirow[t]{2}{*}{ Sig. } & \multicolumn{2}{|c|}{$\begin{array}{l}\text { 95\% Confidence } \\
\text { Interval }\end{array}$} \\
\hline & & & & & $\begin{array}{l}\text { Lower } \\
\text { Bound }\end{array}$ & $\begin{array}{l}\text { Upper } \\
\text { Bound }\end{array}$ \\
\hline \multirow{3}{*}{$\begin{array}{l}\text { High SoP, } \\
\text { High } \\
\text { Income }\end{array}$} & $\begin{array}{l}\text { High SoP, Low } \\
\text { Income }\end{array}$ & $3894.197^{*}$ & 105.180 & 0.000 & 3623.94 & 4164.46 \\
\hline & $\begin{array}{l}\text { Low SoP, High } \\
\text { Income }\end{array}$ & $-1955.742^{*}$ & 109.414 & 0.000 & -2236.88 & -1674.60 \\
\hline & $\begin{array}{l}\text { Low SoP, Low } \\
\text { Income }\end{array}$ & $2295.287^{*}$ & 109.444 & 0.000 & 2014.07 & 2576.50 \\
\hline \multirow{3}{*}{$\begin{array}{l}\text { High SoP, } \\
\text { Low } \\
\text { Income }\end{array}$} & $\begin{array}{l}\text { High SoP, High } \\
\text { Income }\end{array}$ & $-3894.197^{*}$ & 105.180 & 0.000 & -4164.46 & -3623.94 \\
\hline & $\begin{array}{l}\text { Low SoP, High } \\
\text { Income }\end{array}$ & $-5849.940^{*}$ & 97.251 & 0.000 & -6099.83 & -5600.05 \\
\hline & $\begin{array}{l}\text { Low SoP, Low } \\
\text { Income }\end{array}$ & $-1598.910^{*}$ & 97.285 & 0.000 & -1848.88 & -1348.94 \\
\hline \multirow{3}{*}{$\begin{array}{l}\text { Low SoP, } \\
\text { High } \\
\text { Income }\end{array}$} & $\begin{array}{l}\text { High SoP, High } \\
\text { Income }\end{array}$ & $1955.742^{*}$ & 109.414 & 0.000 & 1674.60 & 2236.88 \\
\hline & $\begin{array}{l}\text { High SoP, Low } \\
\text { Income }\end{array}$ & $5849.940^{*}$ & 97.251 & 0.000 & 5600.05 & 6099.83 \\
\hline & $\begin{array}{l}\text { Low SoP, Low } \\
\text { Income }\end{array}$ & $4251.030^{*}$ & 101.848 & 0.000 & 3989.33 & 4512.73 \\
\hline \multirow{3}{*}{$\begin{array}{l}\text { Low SoP, } \\
\text { Low } \\
\text { Income }\end{array}$} & $\begin{array}{l}\text { High SoP, High } \\
\text { Income }\end{array}$ & $-2295.287^{*}$ & 109.444 & 0.000 & -2576.50 & -2014.07 \\
\hline & $\begin{array}{l}\text { High SoP, Low } \\
\text { Income }\end{array}$ & $1598.910^{*}$ & 97.285 & 0.000 & 1348.94 & 1848.88 \\
\hline & $\begin{array}{l}\text { Low SoP, High } \\
\text { Income }\end{array}$ & $-4251.030^{*}$ & 101.848 & 0.000 & -4512.73 & -3989.33 \\
\hline
\end{tabular}

* The mean difference is significant at the 0.05 level. 
Table 14. Sprawl Index x State of Place Index x Income One-way ANOVA

\begin{tabular}{|l|l|l|l|l|l|}
\hline ANOVA \\
\hline Annual Vehicle Miles Traveled per Household for the Regional Typical Household \\
\hline & $\begin{array}{l}\text { Sum of } \\
\text { Squares }\end{array}$ & Df & Mean Square & F & Sig. \\
\hline Between Groups & $9.726 \mathrm{E}+10$ & 7 & $1.389 \mathrm{E}+10$ & $1.987 \mathrm{E}+03$ & 0.000 \\
\hline Within Groups & $6.508 \mathrm{E}+10$ & 9305 & $6.994 \mathrm{E}+06$ & & \\
\hline Total & $1.623 \mathrm{E}+11$ & 9312 & & & \\
\hline
\end{tabular}

Table 15. Tukey HSB Post Hoc Test for Sprawl Index x State of Place Index x Income

\begin{tabular}{|c|c|c|c|c|c|c|}
\hline \multicolumn{7}{|c|}{ Multiple Comparisons } \\
\hline \multicolumn{7}{|c|}{ Dependent Variable: } \\
\hline \multicolumn{7}{|l|}{ Tukey HSD } \\
\hline \multirow{2}{*}{\multicolumn{2}{|c|}{ (I) SoP X Sprawl X Income }} & \multirow{2}{*}{$\begin{array}{l}\text { Mean } \\
\text { Difference } \\
\text { (I-J) }\end{array}$} & \multirow{2}{*}{$\begin{array}{l}\text { Std. } \\
\text { Error }\end{array}$} & \multirow[t]{2}{*}{ Sig. } & \multicolumn{2}{|c|}{ 95\% Confidence Interval } \\
\hline & & & & & Lower Bound & $\begin{array}{l}\text { Upper } \\
\text { Bound }\end{array}$ \\
\hline \multirow[t]{7}{*}{$\begin{array}{l}\text { High SoP, } \\
\text { Compact, } \\
\text { High Income }\end{array}$} & $\begin{array}{l}\text { High SoP, } \\
\text { Compact, Low } \\
\text { Income }\end{array}$ & $2539.049^{*}$ & 99.228 & 0.000 & 2238.23 & 2839.87 \\
\hline & $\begin{array}{l}\text { Low SoP, } \\
\text { Compact, High } \\
\text { Income }\end{array}$ & -70.611 & 137.779 & 1.000 & -488.30 & 347.08 \\
\hline & $\begin{array}{l}\text { Low SoP, } \\
\text { Compact, Low } \\
\text { Income }\end{array}$ & $2053.933^{*}$ & 108.794 & 0.000 & 1724.12 & 2383.75 \\
\hline & $\begin{array}{l}\text { High SoP, } \\
\text { Sprawled, High } \\
\text { Income }\end{array}$ & $-4971.026^{*}$ & 126.052 & 0.000 & -5353.16 & -4588.89 \\
\hline & $\begin{array}{l}\text { High SoP, } \\
\text { Sprawled, Low } \\
\text { Income }\end{array}$ & $-2863.904^{*}$ & 152.349 & 0.000 & -3325.76 & -2402.05 \\
\hline & $\begin{array}{l}\text { Low SoP, } \\
\text { Sprawled, High } \\
\text { Income }\end{array}$ & $-5466.751^{*}$ & 104.473 & 0.000 & -5783.47 & -5150.03 \\
\hline & $\begin{array}{l}\text { Low SoP, } \\
\text { Sprawled, Low } \\
\text { Income }\end{array}$ & $-2912.933^{*}$ & 120.959 & 0.000 & -3279.63 & -2546.24 \\
\hline
\end{tabular}




\begin{tabular}{|c|c|c|c|c|c|c|}
\hline \multicolumn{7}{|c|}{ Multiple Comparisons } \\
\hline \multicolumn{7}{|c|}{ Dependent Variable: } \\
\hline \multicolumn{7}{|c|}{ Tukey HSD } \\
\hline \multirow[t]{7}{*}{$\begin{array}{l}\text { High SoP, } \\
\text { Compact, Low } \\
\text { Income }\end{array}$} & $\begin{array}{l}\text { High SoP, } \\
\text { Compact, High } \\
\text { Income }\end{array}$ & $-2539.049^{*}$ & 99.228 & 0.000 & -2839.87 & -2238.23 \\
\hline & $\begin{array}{l}\text { Low SoP, } \\
\text { Compact, High } \\
\text { Income }\end{array}$ & $-2609.659^{*}$ & 122.224 & 0.000 & -2980.19 & -2239.13 \\
\hline & $\begin{array}{l}\text { Low SoP, } \\
\text { Compact, Low } \\
\text { Income }\end{array}$ & $-485.115^{*}$ & 88.271 & 0.000 & -752.71 & -217.52 \\
\hline & $\begin{array}{l}\text { High SoP, } \\
\text { Sprawled, High } \\
\text { Income }\end{array}$ & $-7510.074^{*}$ & 108.833 & 0.000 & -7840.01 & -7180.14 \\
\hline & $\begin{array}{l}\text { High SoP, } \\
\text { Sprawled, Low } \\
\text { Income }\end{array}$ & $-5402.952^{*}$ & 138.441 & 0.000 & -5822.65 & -4983.26 \\
\hline & $\begin{array}{l}\text { Low SoP, } \\
\text { Sprawled, High } \\
\text { Income }\end{array}$ & $-8005.800^{*}$ & 82.887 & 0.000 & -8257.08 & -7754.52 \\
\hline & $\begin{array}{l}\text { Low SoP, } \\
\text { Sprawled, Low } \\
\text { Income }\end{array}$ & $-5451.982^{*}$ & 102.891 & 0.000 & -5763.90 & -5140.06 \\
\hline \multirow[t]{6}{*}{$\begin{array}{l}\text { Low SoP, } \\
\text { Compact, } \\
\text { High Income }\end{array}$} & $\begin{array}{l}\text { High SoP, } \\
\text { Compact, High } \\
\text { Income }\end{array}$ & 70.611 & 137.779 & 1.000 & -347.08 & 488.30 \\
\hline & $\begin{array}{l}\text { High SoP, } \\
\text { Compact, Low } \\
\text { Income }\end{array}$ & $2609.659^{*}$ & 122.224 & 0.000 & 2239.13 & 2980.19 \\
\hline & $\begin{array}{l}\text { Low SoP, } \\
\text { Compact, Low } \\
\text { Income }\end{array}$ & $2124.544^{*}$ & 130.110 & 0.000 & 1730.11 & 2518.98 \\
\hline & $\begin{array}{l}\text { High SoP, } \\
\text { Sprawled, High } \\
\text { Income }\end{array}$ & $-4900.415^{*}$ & 144.850 & 0.000 & -5339.54 & -4461.29 \\
\hline & $\begin{array}{l}\text { High SoP, } \\
\text { Sprawled, Low } \\
\text { Income }\end{array}$ & $-2793.293^{*}$ & 168.234 & 0.000 & -3303.31 & -2283.28 \\
\hline & $\begin{array}{l}\text { Low SoP, } \\
\text { Sprawled, High } \\
\text { Income }\end{array}$ & $-5396.141^{*}$ & 126.519 & 0.000 & -5779.69 & -5012.59 \\
\hline
\end{tabular}




\begin{tabular}{|c|c|c|c|c|c|c|}
\hline \multicolumn{7}{|c|}{ Multiple Comparisons } \\
\hline \multicolumn{7}{|c|}{ Dependent Variable: } \\
\hline \multicolumn{7}{|c|}{ Tukey HSD } \\
\hline & $\begin{array}{l}\text { Low SoP, } \\
\text { Sprawled, Low } \\
\text { Income }\end{array}$ & $-2842.323^{*}$ & 140.440 & 0.000 & -3268.08 & -2416.57 \\
\hline \multirow[t]{7}{*}{$\begin{array}{l}\text { Low SoP, } \\
\text { Compact, Low } \\
\text { Income }\end{array}$} & $\begin{array}{l}\text { High SoP, } \\
\text { Compact, High } \\
\text { Income }\end{array}$ & $-2053.933^{*}$ & 108.794 & 0.000 & -2383.75 & -1724.12 \\
\hline & $\begin{array}{l}\text { High SoP, } \\
\text { Compact, Low } \\
\text { Income }\end{array}$ & $485.115^{*}$ & 88.271 & 0.000 & 217.52 & 752.71 \\
\hline & $\begin{array}{l}\text { Low SoP, } \\
\text { Compact, High } \\
\text { Income }\end{array}$ & $-2124.544^{*}$ & 130.110 & 0.000 & -2518.98 & -1730.11 \\
\hline & $\begin{array}{l}\text { High SoP, } \\
\text { Sprawled, High } \\
\text { Income }\end{array}$ & $-7024.959^{*}$ & 117.620 & 0.000 & -7381.53 & -6668.38 \\
\hline & $\begin{array}{l}\text { High SoP, } \\
\text { Sprawled, Low } \\
\text { Income }\end{array}$ & $-4917.837^{*}$ & 145.451 & 0.000 & -5358.78 & -4476.89 \\
\hline & $\begin{array}{l}\text { Low SoP, } \\
\text { Sprawled, High } \\
\text { Income }\end{array}$ & $-7520.684^{*}$ & 94.129 & 0.000 & -7806.04 & -7235.33 \\
\hline & $\begin{array}{l}\text { Low SoP, } \\
\text { Sprawled, Low } \\
\text { Income }\end{array}$ & $-4966.866^{*}$ & 112.145 & 0.000 & -5306.84 & -4626.89 \\
\hline \multirow[t]{5}{*}{$\begin{array}{l}\text { High SoP, } \\
\text { Sprawled, } \\
\text { High Income }\end{array}$} & $\begin{array}{l}\text { High SoP, } \\
\text { Compact, High } \\
\text { Income }\end{array}$ & $4971.026^{*}$ & 126.052 & 0.000 & 4588.89 & 5353.16 \\
\hline & $\begin{array}{l}\text { High SoP, } \\
\text { Compact, Low } \\
\text { Income }\end{array}$ & $7510.074^{*}$ & 108.833 & 0.000 & 7180.14 & 7840.01 \\
\hline & $\begin{array}{l}\text { Low SoP, } \\
\text { Compact, High } \\
\text { Income }\end{array}$ & $4900.415^{*}$ & 144.850 & 0.000 & 4461.29 & 5339.54 \\
\hline & $\begin{array}{l}\text { Low SoP, } \\
\text { Compact, Low } \\
\text { Income }\end{array}$ & $7024.959^{*}$ & 117.620 & 0.000 & 6668.38 & 7381.53 \\
\hline & $\begin{array}{l}\text { High SoP, } \\
\text { Sprawled, Low } \\
\text { Income }\end{array}$ & $2107.122^{*}$ & 158.772 & 0.000 & 1625.79 & 2588.45 \\
\hline
\end{tabular}




\begin{tabular}{|c|c|c|c|c|c|c|}
\hline \multicolumn{7}{|c|}{ Multiple Comparisons } \\
\hline \multicolumn{7}{|c|}{ Dependent Variable: } \\
\hline \multicolumn{7}{|c|}{ Tukey HSD } \\
\hline & $\begin{array}{l}\text { Low SoP, } \\
\text { Sprawled, High } \\
\text { Income }\end{array}$ & $-495.726^{*}$ & 113.635 & 0.000 & -840.22 & -151.23 \\
\hline & $\begin{array}{l}\text { Low SoP, } \\
\text { Sprawled, Low } \\
\text { Income }\end{array}$ & $2058.092^{*}$ & 128.955 & 0.000 & 1667.16 & 2449.03 \\
\hline \multirow[t]{7}{*}{$\begin{array}{l}\text { High SoP, } \\
\text { Sprawled, Low } \\
\text { Income }\end{array}$} & $\begin{array}{l}\text { High SoP, } \\
\text { Compact, High } \\
\text { Income }\end{array}$ & $2863.904^{*}$ & 152.349 & 0.000 & 2402.05 & 3325.76 \\
\hline & $\begin{array}{l}\text { High SoP, } \\
\text { Compact, Low } \\
\text { Income }\end{array}$ & $5402.952^{*}$ & 138.441 & 0.000 & 4983.26 & 5822.65 \\
\hline & $\begin{array}{l}\text { Low SoP, } \\
\text { Compact, High } \\
\text { Income }\end{array}$ & $2793.293^{*}$ & 168.234 & 0.000 & 2283.28 & 3303.31 \\
\hline & $\begin{array}{l}\text { Low SoP, } \\
\text { Compact, Low } \\
\text { Income }\end{array}$ & $4917.837^{*}$ & 145.451 & 0.000 & 4476.89 & 5358.78 \\
\hline & $\begin{array}{l}\text { High SoP, } \\
\text { Sprawled, High } \\
\text { Income }\end{array}$ & $-2107.122^{*}$ & 158.772 & 0.000 & -2588.45 & -1625.79 \\
\hline & $\begin{array}{l}\text { Low SoP, } \\
\text { Sprawled, High } \\
\text { Income }\end{array}$ & $-2602.848^{*}$ & 142.247 & 0.000 & -3034.08 & -2171.61 \\
\hline & $\begin{array}{l}\text { Low SoP, } \\
\text { Sprawled, Low } \\
\text { Income }\end{array}$ & -49.030 & 154.760 & 1.000 & -518.20 & 420.14 \\
\hline \multirow[t]{4}{*}{$\begin{array}{l}\text { Low SoP, } \\
\text { Sprawled, } \\
\text { High Income }\end{array}$} & $\begin{array}{l}\text { High SoP, } \\
\text { Compact, High } \\
\text { Income }\end{array}$ & $5466.751^{*}$ & 104.473 & 0.000 & 5150.03 & 5783.47 \\
\hline & $\begin{array}{l}\text { High SoP, } \\
\text { Compact, Low } \\
\text { Income }\end{array}$ & $8005.800^{*}$ & 82.887 & 0.000 & 7754.52 & 8257.08 \\
\hline & $\begin{array}{l}\text { Low SoP, } \\
\text { Compact, High } \\
\text { Income }\end{array}$ & $5396.141^{*}$ & 126.519 & 0.000 & 5012.59 & 5779.69 \\
\hline & $\begin{array}{l}\text { Low SoP, } \\
\text { Compact, Low } \\
\text { Income }\end{array}$ & $7520.684^{*}$ & 94.129 & 0.000 & 7235.33 & 7806.04 \\
\hline
\end{tabular}




\begin{tabular}{|c|c|c|c|c|c|c|}
\hline \multicolumn{7}{|c|}{ Multiple Comparisons } \\
\hline \multicolumn{7}{|c|}{ Dependent Variable: } \\
\hline \multicolumn{7}{|c|}{ Tukey HSD } \\
\hline & $\begin{array}{l}\text { High SoP, } \\
\text { Sprawled, High } \\
\text { Income }\end{array}$ & $495.726^{*}$ & 113.635 & 0.000 & 151.23 & 840.22 \\
\hline & $\begin{array}{l}\text { High SoP, } \\
\text { Sprawled, Low } \\
\text { Income }\end{array}$ & $2602.848^{*}$ & 142.247 & 0.000 & 2171.61 & 3034.08 \\
\hline & $\begin{array}{l}\text { Low SoP, } \\
\text { Sprawled, Low } \\
\text { Income }\end{array}$ & $2553.818^{*}$ & 107.958 & 0.000 & 2226.53 & 2881.10 \\
\hline \multirow[t]{7}{*}{$\begin{array}{l}\text { Low SoP, } \\
\text { Sprawled, Low } \\
\text { Income }\end{array}$} & $\begin{array}{l}\text { High SoP, } \\
\text { Compact, High } \\
\text { Income }\end{array}$ & $2912.933^{*}$ & 120.959 & 0.000 & 2546.24 & 3279.63 \\
\hline & $\begin{array}{l}\text { High SoP, } \\
\text { Compact, Low } \\
\text { Income }\end{array}$ & $5451.982^{*}$ & 102.891 & 0.000 & 5140.06 & 5763.90 \\
\hline & $\begin{array}{l}\text { Low SoP, } \\
\text { Compact, High } \\
\text { Income }\end{array}$ & $2842.323^{*}$ & 140.440 & 0.000 & 2416.57 & 3268.08 \\
\hline & $\begin{array}{l}\text { Low SoP, } \\
\text { Compact, Low } \\
\text { Income }\end{array}$ & $4966.866^{*}$ & 112.145 & 0.000 & 4626.89 & 5306.84 \\
\hline & $\begin{array}{l}\text { High SoP, } \\
\text { Sprawled, High } \\
\text { Income }\end{array}$ & $-2058.092^{*}$ & 128.955 & 0.000 & -2449.03 & -1667.16 \\
\hline & $\begin{array}{l}\text { High SoP, } \\
\text { Sprawled, Low } \\
\text { Income }\end{array}$ & 49.030 & 154.760 & 1.000 & -420.14 & 518.20 \\
\hline & $\begin{array}{l}\text { Low SoP, } \\
\text { Sprawled, High } \\
\text { Income }\end{array}$ & $-2553.818^{*}$ & 107.958 & 0.000 & -2881.10 & -2226.53 \\
\hline
\end{tabular}

* The mean difference is significant at the 0.05 level.

Examining the 3-way interaction term between macroscale and microscale built environment features and income, we found that the combination of compact places, with a higher State of Place Index, and low income, had the lowest levels of VMT. The highest levels of VMT were found among sprawled places, with a lower State of Place Index that were high income. This is likely due to the fact that higher income households with more discretionary income may choose to drive over other methods of transportation especially in auto-oriented areas; whereas lowincome households may not be afforded the same choice, regardless of whether there is or is not good transit access. 
All but one of the combinations, between the eight groups, significantly differed from one another with respect to associated levels of VMT. Sprawled and low income areas did not differ with respect to VMT levels regardless of their State of Place Index; however, there were very few census tracts that fell into each respective group, which may have impacted our ability to detect significant differences in VMT.

Table 16. State of Place Index x Transit One-way ANOVA

\begin{tabular}{|l|l|l|l|l|l|}
\hline ANOVA \\
\hline Annual Vehicle Miles Traveled per Household for the Regional Typical Household \\
\hline & Sum of Squares & df & Mean Square & F & Sig. \\
\hline Between Groups & $2.650 \mathrm{E}+10$ & 3 & $8.833 \mathrm{E}+09$ & $6.053 \mathrm{E}+02$ & 0.000 \\
\hline Within Groups & $1.358 \mathrm{E}+11$ & 9309 & $1.459 \mathrm{E}+07$ & & \\
\hline Total & $1.623 \mathrm{E}+11$ & 9312 & & & \\
\hline
\end{tabular}


Table 17. Tukey HSB Post Hoc Test for State of Place Index x Transit

\begin{tabular}{|c|c|c|c|c|c|c|}
\hline \multicolumn{7}{|c|}{ Multiple Comparisons } \\
\hline \multicolumn{7}{|c|}{ Dependent Variable: } \\
\hline \multicolumn{7}{|l|}{ Tukey HSD } \\
\hline \multirow{2}{*}{\multicolumn{2}{|c|}{ (I) SoPXTransit }} & \multirow{2}{*}{$\begin{array}{l}\text { Mean } \\
\text { Difference (I- } \\
\text { J) }\end{array}$} & \multirow{2}{*}{$\begin{array}{l}\text { Std. } \\
\text { Error }\end{array}$} & \multirow[t]{2}{*}{ Sig. } & \multicolumn{2}{|c|}{$95 \%$ Confidence Interva } \\
\hline & & & & & $\begin{array}{l}\text { Lower } \\
\text { Bound }\end{array}$ & $\begin{array}{l}\text { Upper } \\
\text { Bound }\end{array}$ \\
\hline \multirow[t]{3}{*}{$\begin{array}{l}\text { High SoP, } \\
\text { Good Transit }\end{array}$} & $\begin{array}{l}\text { High SoP, Bad } \\
\text { Transit }\end{array}$ & $-3922.335^{*}$ & 122.532 & 0.000 & -4237.18 & -3607.49 \\
\hline & $\begin{array}{l}\text { Low SoP, Good } \\
\text { Transit }\end{array}$ & $-5126.138^{*}$ & 139.757 & 0.000 & -5485.24 & -4767.03 \\
\hline & $\begin{array}{l}\text { Low SoP, Bad } \\
\text { Transit }\end{array}$ & $-4883.873^{*}$ & 123.589 & 0.000 & -5201.43 & -4566.31 \\
\hline \multirow[t]{3}{*}{$\begin{array}{l}\text { High SoP, } \\
\text { Bad Transit }\end{array}$} & $\begin{array}{l}\text { High SoP, Good } \\
\text { Transit }\end{array}$ & $3922.335^{*}$ & 122.532 & 0.000 & 3607.49 & 4237.18 \\
\hline & $\begin{array}{l}\text { Low SoP, Good } \\
\text { Transit }\end{array}$ & $-1203.804^{*}$ & 116.274 & 0.000 & -1502.57 & -905.04 \\
\hline & $\begin{array}{l}\text { Low SoP, Bad } \\
\text { Transit }\end{array}$ & $-961.538^{*}$ & 96.239 & 0.000 & -1208.82 & -714.25 \\
\hline \multirow[t]{3}{*}{$\begin{array}{l}\text { Low SoP, } \\
\text { Good Transit }\end{array}$} & $\begin{array}{l}\text { High SoP, Good } \\
\text { Transit }\end{array}$ & $5126.138^{*}$ & 139.757 & 0.000 & 4767.03 & 5485.24 \\
\hline & $\begin{array}{l}\text { High SoP, Bad } \\
\text { Transit }\end{array}$ & $1203.804^{*}$ & 116.274 & 0.000 & 905.04 & 1502.57 \\
\hline & $\begin{array}{l}\text { Low SoP, Bad } \\
\text { Transit }\end{array}$ & 242.265 & 117.387 & 0.165 & -59.36 & 543.89 \\
\hline \multirow[t]{3}{*}{$\begin{array}{l}\text { Low SoP, } \\
\text { Bad Transit }\end{array}$} & $\begin{array}{l}\text { High SoP, Good } \\
\text { Transit }\end{array}$ & $4883.873^{*}$ & 123.589 & 0.000 & 4566.31 & 5201.43 \\
\hline & $\begin{array}{l}\text { High SoP, Bad } \\
\text { Transit }\end{array}$ & $961.538^{*}$ & 96.239 & 0.000 & 714.25 & 1208.82 \\
\hline & $\begin{array}{l}\text { Low SoP, Good } \\
\text { Transit }\end{array}$ & -242.265 & 117.387 & 0.165 & -543.89 & 59.36 \\
\hline
\end{tabular}

*The mean difference is significant at the 0.05 level.

When evaluating the interaction effect of microscale built environment features and transit, the combination of compact places with a higher State of Place Index and good access to transit had the lowest levels of VMT. This supports the popular notion that transit-oriented developments with urban design features that support walking and biking to said transit, significantly impacts people's choice to drive.

All but one of the combinations between groups significantly differed from one another with respect to associated levels of VMT: in places with a lower State of Place Index, there was no significant difference with respect to VMT when comparing those with good vs. bad access to 
transit. Again, this supports the notion that transit access alone may not serve to reduce driving; instead, supportive urban design is also needed to impact the choice of transportation mode.

Table 18. Sprawl Index x State of Place Index x Income x Transit One-way ANOVA

\begin{tabular}{|c|c|c|c|c|c|}
\hline \multicolumn{6}{|l|}{ ANOVA } \\
\hline \multicolumn{6}{|c|}{ Annual Vehicle Miles Traveled per Household for the Regional Typical Household } \\
\hline & Sum of Squares & df & Mean Square & $\mathrm{F}$ & Sig. \\
\hline $\begin{array}{l}\text { Between } \\
\text { Groups }\end{array}$ & $1.199 \mathrm{E}+11$ & 15 & $7.997 \mathrm{E}+09$ & $1.754 \mathrm{E}+03$ & 0.000 \\
\hline Within Groups & $4.239 \mathrm{E}+10$ & 9297 & $4.560 \mathrm{E}+06$ & & \\
\hline Total & $1.623 \mathrm{E}+11$ & 9312 & & & \\
\hline
\end{tabular}

Evaluating the four-way interaction term between microscale and macroscale built environment features, transit, and income, we found that low income, compact places with a higher State of Place Index and good access to transit had the lowest levels of VMT. This finding is supportive of popular conventions that pedestrian- and transit-oriented places with good urban design most optimally reduce driving rates.

With respect to between-group differences, all combinations were statistically significant except for differences between places with a higher vs. a lower State of Place Index did not significantly impact VMT in:

- Compact, high income places with good transit (potentially because higher discretionary incomes may be impacting their choices more so than urban design)

- Compact, low income places with bad transit (potentially because of a jobs-housing disconnect for lower income households - which has equity implications)

- Sprawled, high income places with bad transit (again, likely because discretionary income affords higher income households the ability to drive, especially when they live in places where that is the most "convenient" choice)

- Sprawled, low income places with good transit (which also has equity implications as this might mean that lower income households are walking or bicycling to transit despite urban design that does not accommodate this safely)

However, it is critical to note that as with the three-way interaction, statistically significant differences in VMT may not be detected among some groups, as some groups contained only a few census tracts. Also, we did not report results when there were no places that fell into a specific group within the $4 \mathrm{X} 4$ matrix.

In addition to running One-Way ANOVAs to better understand the interactions between microscale and macroscale built environment features, transit, and income, we estimated VMT 
hat according to the specified model. In other words, we specified hypothetically possible levels of both high and low scores among the four variables and then calculated what VMT would be if those conditions were present. As shown in Table 19, among all possible combinations, compact, low-income places with a higher State of Place Index and good access to transit produced the lowest levels of VMT (13,063 mi) as compared to sprawled, low-income places, with a lower State of Place Index and poor access to transit $(28,110 \mathrm{mi})$.

Table 19. Results of Y hat (Predicted VMT) Across Place Types

\begin{tabular}{|l|l|}
\hline Type & VMT \\
\hline High SoP, Compact, Low Income, Good Transit & 13881.1762 \\
\hline Low SoP, Compact, Low Income, Good Transit & 13897.77287 \\
\hline High SoP, Compact, High Income, Good Transit & 14154.19665 \\
\hline Low SoP, Compact, High Income, Good Transit & 16642.73879 \\
\hline Low SoP, Compact, Low Income, Bad Transit & 16929.79335 \\
\hline High SoP, Compact, Low Income, Bad Transit & 16984.36392 \\
\hline High SoP, Compact, High Income, Bad Transit & 17821.93025 \\
\hline High SoP, Sprawled, Low Income, Good Transit & 17968.12166 \\
\hline Low SoP, Compact, High Income, Bad Transit & 18733.84945 \\
\hline High SoP, Sprawled, Low Income, Bad Transit & 22358.1436 \\
\hline High SoP, Sprawled, High Income, Good Transit & 22792.5059 \\
\hline Low SoP, Sprawled, High Income, Good Transit & 23458.03671 \\
\hline High SoP, Sprawled, High Income, Bad Transit & 26117.51573 \\
\hline Low SoP, Sprawled, High Income, Bad Transit & 26120.35366 \\
\hline Low SoP, Sprawled, Low Income, Good Transit & 28298.67711 \\
\hline Low SoP, Sprawled, Low Income, Bad Transit & 29185.97388 \\
\hline
\end{tabular}

Tables 20-23 show how the combination of three of the variables from the four-way interaction compare across high vs. low scores of the fourth variable, with respect to VMT. Looking at places with a high vs. a low State of Place Index, sprawled, low income places with good transit had the largest reduction in VMT scores (33.4\%), followed by sprawled, low income places with bad transit (21.3\%). When comparing high vs. low income, the smallest difference in VMT occurred in compact places, with a high State of Place Index and good access to transit. In two instances, places with lower incomes had higher VMT than places with higher incomes: sprawled places with a lower State of Place Index, with or without access to good transit. In terms of compact vs. sprawled places, the largest reductions in VMT were observed in low-income places with a low State of Place Index, with either good or bad access to transit (51.7\% and $42.7 \%$, respectively). Finally, the difference in VMT in places with good vs. bad transit access was most marked in four types of places: compact places with a higher State of Place Index, both in high and low-income areas 
(20.7\% and 19.2\%, respectively); compact, low-income places with a lower State of Place Index (18.8\%); and sprawled, low-income places with a higher State of Place Index.

Table 20. Results of Y hat (Predicted VMT) Across Place Types Comparing a High vs. Low State of Place Index

\begin{tabular}{|l|l|l|l|l|}
\hline Conditions & High SoP & Low SoP & Diff & \% Diff \\
\hline $\begin{array}{l}\text { Sprawl, Low Income, } \\
\text { Good Transit }\end{array}$ & 17968.12166 & 28298.6771 & -10330.55545 & $-36.51 \%$ \\
\hline $\begin{array}{l}\text { Sprawl, Low Income, Bad } \\
\text { Transit }\end{array}$ & 22358.1436 & 29185.9739 & -6827.830282 & $-23.39 \%$ \\
\hline $\begin{array}{l}\text { Compact, Low Income, } \\
\text { Good Transit }\end{array}$ & 13881.1762 & 16642.7388 & -2761.562592 & $-16.59 \%$ \\
\hline $\begin{array}{l}\text { Compact, High Income, } \\
\text { Good Transit }\end{array}$ & 14154.19665 & 16642.7388 & -2488.542147 & $-14.95 \%$ \\
\hline $\begin{array}{l}\text { Compact, Low Income, } \\
\text { Bad Transit }\end{array}$ & 16984.36392 & 18733.8494 & -1749.485533 & $-9.34 \%$ \\
\hline $\begin{array}{l}\text { Compact, High Income, } \\
\text { Bad Transit }\end{array}$ & 17821.93025 & 18733.8494 & -911.9191944 & $-4.87 \%$ \\
\hline $\begin{array}{l}\text { Sprawl, High Income, } \\
\text { Good Transit }\end{array}$ & 22792.5059 & 23458.0367 & -665.5308167 & $-2.84 \%$ \\
\hline $\begin{array}{l}\text { Sprawl, High Income, } \\
\text { Bad Transit }\end{array}$ & 26117.51573 & 26120.3537 & -2.837930354 & $-0.01 \%$ \\
\hline & Average & -3217.28299 & $-13.56 \%$ \\
\hline
\end{tabular}


Table 21. Results of Y hat (Predicted VMT) Across Place Types Comparing a High vs. Low Income

\begin{tabular}{|l|l|l|l|l|}
\hline Conditions & High Income & Low Income & Diff & $\%$ Diff \\
\hline $\begin{array}{l}\text { Low SoP, Sprawled, Good } \\
\text { Transit }\end{array}$ & 23458.03671 & 28298.6771 & -4840.640398 & $-17.11 \%$ \\
\hline $\begin{array}{l}\text { Low SoP, Sprawled, Bad } \\
\text { Transit }\end{array}$ & 26120.35366 & 29185.9739 & -3065.62022 & $-10.50 \%$ \\
\hline $\begin{array}{l}\text { High SoP, Compact, } \\
\text { Good Transit }\end{array}$ & 14154.19665 & 13881.1762 & 273.0204449 & $1.97 \%$ \\
\hline $\begin{array}{l}\text { High SoP, Compact, Bad } \\
\text { Transit }\end{array}$ & 17821.93025 & 16984.3639 & 837.5663381 & $4.93 \%$ \\
\hline $\begin{array}{l}\text { Low SoP, Compact, Bad } \\
\text { Transit }\end{array}$ & 18733.84945 & 16929.7933 & 1804.056103 & $10.66 \%$ \\
\hline $\begin{array}{l}\text { Low SoP, Compact, Good } \\
\text { Transit }\end{array}$ & 16642.73879 & 13881.1762 & 2761.562592 & $19.89 \%$ \\
\hline $\begin{array}{l}\text { High SoP, Sprawled, Bad } \\
\text { Transit }\end{array}$ & 26117.51573 & 22358.1436 & 3759.372132 & $16.81 \%$ \\
\hline $\begin{array}{l}\text { High SoP, Sprawled, } \\
\text { Good Transit }\end{array}$ & 22792.5059 & 17968.1217 & 4824.384239 & $26.85 \%$ \\
\hline & Average & 794.2126539 & $6.69 \%$ \\
\hline
\end{tabular}


Table 22. Results of Y hat (Predicted VMT) Across Place Types Comparing Compact vs. Sprawled Places

\begin{tabular}{|l|l|l|l|l|}
\hline Conditions & Compact & Sprawl & Diff & $\%$ Diff \\
\hline $\begin{array}{l}\text { Low SoP, Low Income, } \\
\text { Good Transit }\end{array}$ & 13897.77287 & 28298.6771 & -14400.90424 & $-50.89 \%$ \\
\hline $\begin{array}{l}\text { Low SoP, Low Income, } \\
\text { Bad Transit }\end{array}$ & 16929.79335 & 29185.9739 & -12256.18053 & $-41.99 \%$ \\
\hline $\begin{array}{l}\text { High SoP, High } \\
\text { Income, Good Transit }\end{array}$ & 14154.19665 & 22792.5059 & -8638.309249 & $-37.90 \%$ \\
\hline $\begin{array}{l}\text { High SoP, High } \\
\text { Income, Bad Transit }\end{array}$ & 17821.93025 & 26117.5157 & -8295.585474 & $-31.76 \%$ \\
\hline $\begin{array}{l}\text { Low SoP, High } \\
\text { Income, Bad Transit }\end{array}$ & 18733.84945 & 26120.3537 & -7386.50421 & $-28.28 \%$ \\
\hline $\begin{array}{l}\text { Low SoP, High } \\
\text { Income, Good Transit }\end{array}$ & 16642.73879 & 23458.0367 & -6815.297918 & $-29.05 \%$ \\
\hline $\begin{array}{l}\text { High SoP, Low } \\
\text { Income, Bad Transit }\end{array}$ & 16984.36392 & 22358.1436 & -5373.77968 & $-24.03 \%$ \\
\hline $\begin{array}{l}\text { High SoP, Low } \\
\text { Income, Good Transit }\end{array}$ & 13881.1762 & 17968.1217 & -4086.945455 & $-22.75 \%$ \\
\hline & Average & -8406.68835 & $-33.33 \%$ \\
\hline
\end{tabular}


Table 23. Results of Y hat (Predicted VMT) Across Place Types Comparing Good to Poor Transit Access

\begin{tabular}{|l|l|l|l|l|}
\hline Conditions & Good Transit & Bad Transit & Diff & $\%$ Diff \\
\hline High SoP, Compact, High Income & 14154.19665 & 17821.9303 & -3667.733607 & $-20.58 \%$ \\
\hline High SoP, Sprawl, Low Income & 17968.12166 & 22358.1436 & -4390.021939 & $-19.64 \%$ \\
\hline High SoP, Compact, Low Income & 13881.1762 & 16984.3639 & -3103.187714 & $-18.27 \%$ \\
\hline Low SoP, Compact, Low Income & 13897.77287 & 16929.7933 & -3032.020476 & $-17.91 \%$ \\
\hline High SoP, Sprawl, High Income & 22792.5059 & 26117.5157 & -3325.009832 & $-12.73 \%$ \\
\hline Low SoP, Compact, High Income & 16642.73879 & 18733.8494 & -2091.110655 & $-11.16 \%$ \\
\hline Low SoP, Sprawl, High Income & 23458.03671 & 26120.3537 & -2662.316946 & $-10.19 \%$ \\
\hline Low SoP, Sprawl, Low Income & 28298.67711 & 29185.9739 & -887.296768 & $-3.04 \%$ \\
\hline & & Average & -2894.83724 & $-14.19 \%$ \\
\hline
\end{tabular}


Table 24. Summary of Quantitative Results

Overall, disadvantaged communities had significantly lower VMT than did advantaged communities, scored significantly lower on the State of Place Index, were significantly less sprawled, had significantly higher access to transit, had significantly higher percentage of households with no vehicle access, and had significantly lower median household incomes.

The combination of compact places, with a higher State of Place Index, low income, and good access to transit had the lowest levels of VMT. This finding is supportive of popular conventions that pedestrian and transitoriented places with good urban design most optimally reduce driving rates. This also supports the popular notion that transit-oriented developments with urban design features that support walking and biking to said transit, significantly impacts people's choice to drive. The highest levels of VMT were found among sprawled places, with a lower State of Place Index that were high income. This may be explained by the luxury of automobile choice for households with higher discretionary income.

Compact, low-income places with a higher State of Place Index and good access to transit produced the lowest levels of VMT $(13,063 \mathrm{mi})$ as compared to sprawled, low-income places, with a lower State of Place Index and poor access to transit $(28,110 \mathrm{mi})$.

When looking at how macro-level built environment features interacted with micro-level built environment features to impact VMT (controlling for other factors), areas that were compact with a higher State of Place Index had the lowest levels of VMT whereas sprawled areas with a lower State of Place Index had the highest levels of VMT.

All but one of the combinations between groups significantly differed from one another with respect to associated levels of VMT: in places with a lower State of Place Index, there was no significant difference with respect to VMT when comparing those with good vs. bad access to transit. Again, this supports the notion that transit access alone may not serve to reduce driving; instead, supportive urban design is also needed to impact the choice of transportation mode.

While on average, macroscale built environment features had the largest impact on reducing VMT (35\%), as compared to transit access (15\%), microscale features (13\%), and income (6\%), based on our hypothetical scenario (outlined in Table 19), it is not appropriate to deduce that macro-level built environment features are the most important to address in mitigating VMT, but rather, the combination of all four factors must be considered.

With respect to between-group differences, all combinations were statistically significant except for differences between places with a higher vs. a lower State of Place Index did not significantly impact VMT in:

Compact, high-income places with good transit (potentially because higher discretionary incomes may be impacting their choices more so than urban design)

Compact, low-income places with bad transit (potentially because of a jobs-housing disconnect for lower income households—which has equity implications)

Sprawled, high income places with bad transit (again, likely because discretionary income affords higher income households the ability to drive, especially when they live in places where that is the most "convenient" choice

Sprawled, low-income places with good transit (which also has equity implications as this might mean that lower income households are walking or bicycling to transit despite urban design that does not accommodate this safely)

However, it is critical to note that as with the three-way interaction, statistically significant differences in VMT may not be detected among some groups, as some groups contained only a few census tracts. 


\section{Qualitative Interview Results}

VMT is considered a more appropriate and holistic metric to assess the environmental impacts of development. There is a consensus among transportation planners and professionals that VMT is a considerably more appropriate metric for evaluating development impacts under the CEQA. SB 743 aligned the environmental sustainability objectives of local governments with the environmental protection aspects of the CEQA by replacing LOS with VMT, according to interview participants. For example, some interviewees discussed how SB 743 has supported the implementation of their local climate action plan. Others mentioned how SB 743 can be used to further justify infill development, transit-oriented development, and other types of smart growth projects.

Shifting to a VMT perspective allows for a holistic approach to regional transportation planning and addresses equity along with the environment in mitigating impacts. "The perspective or paradigm change that [replacing LOS with VMT] represents [forces us] to look at the entire system, and particularly [focus on] the impacts that vehicles are causing in the world" one interviewee explained. Solutions that are developed based on such a holistic approach tend to be "better environmental, social, and public dollar investments," allowing the environment and social equity to be gauged by a new measure. For example, interviewees discussed how low VMT areas are more likely to offer better air quality and provide better access to jobs, services, and amenities. This is because low VMT areas or "VMT efficient" areas tend to be closer to employment, shopping or entertainment destinations, or otherwise provide good alternative mobility options.

Transportation experts are still exploring and learning about off-site VMT mitigation strategies. Many efforts in off-site VMT mitigation are currently in the development stages, and many jurisdictions still rely on expiring LOS frameworks. Unsurprisingly, progress in determining how to develop, implement, and evaluate off-site VMT mitigation strategies is not homogenous throughout the State of California. Larger, progressive, and more affluent cities are more likely to have developed relatively advanced VMT calculators to take charge in creating effective VMT mitigation strategies. On the other hand, smaller communities or jurisdictions with limited capacity, remain busy learning from others and exploring strategies for VMT mitigation. Some interviewees were concerned about the uneven development and implementation of off-site VMT mitigation measures across the state. For example, sprawled communities might have fewer opportunities to mitigate VMT, and thus are likely to delay implementation.

In addition, the recent introduction of off-site VMT mitigation and the limited guidance from the State has motivated local jurisdictions to either create their own resources or learn from other jurisdictions. Local governments have also organized a discussion group to collaborate on exploring different avenues of VMT mitigation. The fact that this small group has organically formed perhaps indicates the need for larger, more formal workshops for VMT discussion.

Interviewees revealed several key questions that remain unanswered but have been the subject of discussions. For example, there is no clear agreement for what should be considered "off-site" mitigation. A few interviewees considered a transportation improvement across the street from the development to be off-site. On the other hand, others expected off-site mitigation to happen across county lines within the region, or elsewhere in the state. Related to this is the question of who should own the bank for off-site mitigation. Although there was a consensus among interviewees 
that banks would likely be more effectively managed at the regional level, experts are still exploring their options. Lastly, although experts agree that promoting regional goals should be at the core of off-site VMT mitigation, ensuring that money generated by a development is used to satisfy the immediate neighborhood needs is also important.

Of the few jurisdictions that have practiced off-site VMT mitigation in any form, the initial perception is that off-site VMT mitigation through the CEQA is unreliable due to its dependence on the development cycle. The demand for development is uneven across the state and fluctuates with the state of the economy. As a result, experts did not express confidence that off-site VMT mitigation tied to development alone will help them meet their GHG emissions mitigation or other transportation goals.

Additionally, interviewees were concerned that larger infrastructure investments, that more effectively reduce VMT, are not considered attractive options for off-site VMT mitigation. In practice, off-site VMT mitigation measures are currently limited to small-scale improvements like curb and roadway improvements. One planner interviewed stated that the incremental approach that cities take in VMT mitigation satisfies the public's desire to "see some kind of return," but the extent of benefits of these low-risk investments are somewhat shallow. Another interviewee was concerned that allowing developers to select from a list of off-site projects will result in the selection of less significant programmatic interventions, such as TDM measures with limited VMT mitigation potential.

Transportation experts discussed three main challenges involved with VMT impact mitigation. The main challenges described by the interviewees can be summarized in three categories: the lack of reliable, standardized VMT measure and evaluation tools; the lack of a strong legal foundation for VMT as a component of the CEQA; and the challenge of distributing off-site VMT mitigation equitably.

1. The challenge of VMT estimation and mitigation evaluation: there is a huge degree of uncertainty in VMT estimation and mitigation evaluation. As stated by one planner, "We don't have the level of certainty we need around what it means to reduce VMT at a one to one level... we don't have a level of accuracy [and] our error bars are still very big." Jurisdictions across the state simply do not have the tools at their disposal to clearly state the amount of VMT generated by a project, the impact of a specific mitigation strategy, and the overall effectiveness of that strategy over time. A few interviewees mentioned that they use more than one tool to estimate VMT impacts, since local experts do not have confidence in the existing tools. This allows them to develop a range of VMT impacts as opposed to an exact number and understand the sensitivity of VMT impacts to various assumptions.

2. Potential legal challenges: one transportation analyst interviewed in addition to other experts stated that the CEQA is primarily supported by various case laws over the decades. Because VMT is a relatively new addition to the CEQA, the lack of relevant case laws makes it difficult for local governments to know to what extent they can push their VMT reduction goals. This also connects with the idea of establishing a legal nexus for VMT impacts in an exchange system, where the legal landscape favors developers at the moment, due to the lack of precedence. Interviewees argued that establishing an "essential nexus" to a governmental purpose means that the government should legally be able to reject the project altogether if the developer does not comply with the VMT mitigation requirements. Not all interviewees thought that their local government could reasonably 
require developers to do a lot more to reduce VMT. Additionally, experts were concerned about litigation risks for mitigation requirements that developers do not consider proportional to the adverse environmental impacts caused by the development.

3. Equity challenges: the last challenge involves the equitable implementation of VMT strategies. We found that experts defined equity differently, making it difficult to identify key equity challenges that impact all communities. Some interviewees mentioned that the existing community adjacent to a development would naturally expect some of the VMT mitigation to occur in their immediate area, since they are the ones being impacted. "[You can] say look we're going to build something over there [in a neighborhood] that is generally underserved. That's good as it advances equity, but the neighborhood that's immediately next to the building [also] has a legitimate complaint [that they're] not being included. Equity and inclusion should both be considered," stated an interviewee. This statement suggests that distributional equity does not justify excluding communities that are being directly impacted by a development.

A second group of interviewees stressed the importance of racial equity as opposed to geographic equity. In their perspective, off-site VMT mitigation strategies should be designed in a way to address social and historical injustices, and inequalities experienced by communities of color. As one interview explained: "racial equity [should] frame the [VMT mitigation] program in a manner that transportation investments benefit communities of color, ...but even then...this doesn't necessarily address the impacts of the VMT increase [as a result of new development] on such communities." Thus, achieving racial equity remains a challenge.

A third group of interviewees discussed equity challenges in a regional rather than local context. In their perspective, VMT should be considered a regional issue that crosses jurisdictional boundaries. According to these experts, mitigation measures need to be looked at from the regional perspective, which could mean that the immediate area would not receive tangible benefits from VMT banks and exchanges. A "regional perspective" can help governments select the most costeffective measures or "the biggest bang for the buck" that benefit the entire region. These experts are aware that equity is an enormous concern stemming from the regional perspective towards VMT, where the systematic absence of VMT mitigation in disadvantaged communities can exacerbate social issues across all scales of government.

Off-site VMT mitigation can help fund transportation infrastructure. Off-site VMT mitigation was nearly unanimously seen as a welcome addition to overall transportation infrastructure funding, especially because of the geographic flexibility it offers. A senior planner interviewed provides a succinct picture of the main opportunity with off-site VMT mitigation: "we are able to utilize funds from one area of the city... but use those funds to build transportation infrastructure where we're going to get the greatest use of that infrastructure and therefore, the greatest VMT reductions."

This geographic flexibility also helps alleviate other urban issues, such as the lack of housing. In areas where housing is desperately needed but VMT mitigation may not be possible, off-site mitigation enables cities to not only allow development in an area, but also promote overall regional VMT goals. Although it would be ideal to implement VMT mitigation fully in the area of development, off-site VMT mitigation provides at least an opportunity to reduce VMT in every scenario. Other benefits mentioned by interviewees include providing general access to 
transportation services across more cities and having individual neighborhoods transition into more travel-efficient areas.

Nevertheless, experts acknowledge the need to safeguard equity in off-site VMT mitigation investments. Some cities have developed a tool, or otherwise distinct mechanism, to assess the equity implications of transportation improvements. For example, the City of San Diego's Climate Equity Index assesses the level of access that residents within a census tract have to opportunities and evaluates the magnitude of potential climate change impacts on these areas. ${ }^{61}$ The tool helps transportation planners in the city identify vulnerable populations, which can be used to assess the equity implications of off-site VMT mitigation investments.

Caution is needed in developer-dependent VMT banks and exchanges. Although professionals recognize the potential of VMT banks and exchanges for funding regional transportation projects, there is a consensus that off-site VMT mitigation requirements should be carefully balanced with a variety of factors. For example, experts generally agree that VMT mitigation requirements imposed upon developers should be commensurate to the VMT impact of the development. Another factor to consider is the existing local government demands for developers. For example, many cities already require a variety of small-scale design inclusions, such as bike facilities, transit stops, and pedestrian accommodations. Generally, the requirements for developers are stricter in areas with higher demand for development. In such areas, local governments might have limited reasonable VMT mitigation options to add to their existing requirements. Transportation planners also acknowledge that the burden of developing expensive regional transit services cannot be placed solely on developers. For example, one major concern discussed by interviewees was that strict requirements might discourage developers from building much-needed affordable housing. Also, if the funds are coming from developers, then the availability of those funds would be dependent on when or if development occurs. The last concern was that attaching large fees to support public transportation to projects would potentially discourage developers from building much-needed housing across the state.

Before discussing what specific mitigation strategies should be implemented, the primary discussion to have is whether a development is appropriate for the area. Interviewees discussed the limitation of relying on the CEQA guidelines to determine VMT mitigation options. According to the experts interviewed, the biggest opportunities for VMT mitigation are related to the location of the development site, and not what can be done after the fact. Cities and metropolitan planning organizations are generally trying to encourage higher density development near transit and/or areas with better access to jobs, amenities, and services. Yet, the demand for affordable housing in California has pushed development into "VMT-inefficient" areas, where residents need to commute long distances to access employment, entertainment, and services. Interviewees stressed the importance of identifying and encouraging development in "VMT-efficient" areas, or areas where residents do not have to drive to locations of interest. If a development site has been already selected in a "VMT-inefficient" area, and it is determined that such development will have significant VMT impacts under CEQA, it might be too late to harness the best opportunities of VMT mitigation in the region.

Local governments desire state-level intervention in VMT research and implementation. Because of cross-jurisdictional conflicts, competing interests, and the varying economic power of local governments, the state plays an important role in the implementation of off-site VMT mitigation. 
The authority of the state to promote collaboration and provide funding, among other benefits, is a key sought-after element for successful implementation of SB 743.

Interviewees considered a combination of local, regional, and state level involvement appropriate. Since VMT reduction often involves multiple jurisdictions, the administrative burden would be better handled at the state level. Several interviewees argued that the state could establish a consistent, state-wide VMT mitigation program similar to California's cap-and-trade. The capand-trade program allows revenues generated to be deposited into a fund and then appropriated to relevant agencies to implement climate programs. It is required by law that $35 \%$ of cap-andtrade revenues benefit disadvantaged communities. The consensus among interviewees was that the bank should be established by the state and managed at the regional level with local input. The regional entity should incorporate local voices through legal entities, such as joint power authorities. This highlights a concern in a regional approach-will smaller local cities see the benefits of VMT mitigation within their boundaries?

The state could also help in accelerating the body of knowledge related to VMT impact estimation, mitigation, and progress evaluation. Local governments are developing VMT mitigation estimation tools and strategies in a piecemeal fashion, using their own boundaries as research areas. Interviewees agreed that everyone would benefit if the state took the initiative in establishing itself as the main source for VMT resources. Interviewees cited that the lack of literature surrounding VMT creates concern in transitioning away from LOS, which has been used in CEQA for decades.

A necessary application of VMT research is the development of more robust VMT estimation and evaluation tools. Current tools mentioned by the interviewees include the SANDAG model, the California Emissions Estimator Model, and the NCST calculator. These tools utilize factors such as the number of trips, employment locations, and development size, in combination with demographic information to provide a rough estimate. One criticism is that these tools can only provide a rough idea of VMT, and often the different calculators will produce different ranges. Besides sketch-based tools, robust travel demand models used to shape regional transportation also assist in forecasting VMT but ultimately, project-level physical and zoning incompatibilities could create discrepancies. Experts are reluctant to rely on estimation tools that do not consider projectlevel, contextual variables. "For example, how does a bike project affect VMT differently in a low income area... right now, we only have [models that show] if you do a bike project, you're going to reduce VMT in general without looking into the context... so we need much more information to desegregate that information and say, it depends, if you implement the bike project in this [specific] area, you're going to see [greater] VMT reduction,” one interviewee explained.

Limited research and consequently the lack of context-sensitive, accurate, and reliable VMT tools has made the mandated transition to VMT difficult for some. In one interview, a planner working in a relatively smaller city mentioned that there is "a lack of trust in the tools that are available," and that these tools do not effectively capture the whole story happening within the city, leading to inaccurate or overestimated VMT calculations. These estimates become obstacles in getting a project approved because the VMT mitigation obligation could be disproportionate to the actual VMT impact. In summation, many interviewees desire more sophisticated VMT estimation tools for ex-ante evaluation of alternative mitigation strategies, as well as tools to be used for ex-post evaluation of VMT reduction outcomes. 
Equity is a foundational aspect of implementing VMT mitigation. Ensuring the equitable and proportionate distribution of VMT mitigation benefits involves first identifying vulnerable populations and communities of concern. Several planners mentioned communities of concern that serve as target areas for improvements through mitigation programs. There are a variety of ways to accomplish this, with some jurisdictions developing an equity assessment tool to determine the allocation of funds to urban communities of color. The Bay Area's Metropolitan Transportation Commission (MTC) has developed Community-Based Transportation Plans (CBTPs) that help identify specific project sites. San Diego's "Climate Equity Index" is another tool that is used to address historical inequities suffered by communities of color.

Equity analysis involves more than just looking at the dollar amount of investments but rather how the investments benefit the community. Planners are generally aware that spending an equal dollar amount for transportation projects across the city or region does not necessarily result in an equitable outcome. For example, planners referred to different needs and consequently desired transportation services between communities with a larger proportion of senior residents as opposed to communities consisting of predominately younger families or young professionals. Interviewees used examples such as bicycle share programs and micro-mobility options to illustrate how similar investments in different communities might not necessarily generate the same value for the community, or the same VMT mitigation impact. As such, developing VMT estimation tools that consider contextual variables is key for equity analysis.

To combat mobility equity problems, experts stressed the importance of engaging with the community in a meaningful way. This involves three important steps. The first step is working with the community to identify current mobility needs and historic disinvestments in low-income communities of color. This is referred to as a "participatory problem diagnosis and needs assessment" which helps transportation planners and professionals "diagnose what is missing." The second step is goal setting and alternative development. The experts referred to three common goals that are at the core of an equitable mobility system: 1) developing accessible, affordable, reliable, safe, and efficient mobility options; 2) addressing the negative environmental and health impacts of transportation by reducing GHG emissions, air pollutants and other environmental harms; and 3) safeguarding equitable distribution of economic opportunity. In the context of VMT mitigation projects, transportation experts discussed not only the importance of equitable access to jobs but also the local economic impact of such investments. As such, the third and final step of community engagement entails placing investment decision-making power in the hands of communities. 


\section{Discussion and Recommendations}

Mitigation strategies must account for how microscale built environment attributes, macroscale built environment attributes, transit access, and income interact to impact VMT. Overall, our quantitative findings support a nuanced, multi-factor understanding of the context in which new developments are being proposed when implementing off-site mitigation measures to offset potential increases in VMT near the project site. Specifically, the finding that there is a significant interaction between macroscale built environment attributes, microscale urban design features, transit access, and income suggests that all four factors must be considered in any mitigation strategy. While on average, macroscale built environment features had the largest impact on reducing VMT (35\%), as compared to transit access (15\%), microscale features (13\%), and income (6\%), based on our hypothetical scenario (outlined in Table 19), it is not appropriate to deduce that macro-level built environment features are the most important to address in mitigating VMT, but rather, the combination of all four factors must be considered.

For example, if a new development were proposed within a sprawled, low-income area, it is of note that the difference between better vs. lower quality microscale urban design translates into an over a 9,000 mi decrease in VMT. In practice, this means that if a proposed project were obliged to do on-site urban design-based mitigation, it could reduce VMT by up to one-third. On the other hand, off-site mitigation would significantly burden low-income communities in sprawled places, especially those with good transit access. Another way to look at this is the combination of two potential mitigation measures-better urban design and transit access-on VMT. In our hypothetical predicted scenario, for example, the difference in VMT between a sprawled, lowincome place with good access to transit and better microscale urban design features vs. a sprawled, lowincome place with poor access to transit and lower quality microscale urban design was over 10,000 miles annually, per household. As such, it is critical that those implementing SB 743 consider the context of the proposed development site with respect to its micro- and macroscale built environment features, transit access, and income, when determining (1) what VMT mitigation measures are warranted and (2) whether off-site mitigation would be appropriate and/or equitable.

A combination of access to compact places, high-quality microscale urban design features, and transit access is especially important for mitigating VMT in low-income communities and ensuring equity. From an equity perspective, access to compact places with better quality microscale urban design features and good transit puts low- and high-income people on a more level playing field. For example, there was only a 3.8\% difference between VMT in low vs. high income areas in these kinds of areas. In comparison, sprawled places with lower quality microscale urban design features (with either good or bad access to transit) were the only two types of places in which lower income communities had higher VMT than higher income communities. These findings suggest that micro- and macroscale built environment features impact VMT more in lowincome communities than in high income communities. Accordingly, allowing off-site mitigation measures for projects based in low-income places is likely to create a disproportionately undue burden on already vulnerable communities.

The continual development of the VMT body of knowledge through grants should be managed at the state level. Currently, compared to what is known about LOS and the factors that impact it, there is a dearth of research around what aspects of development impact VMT, due in part to 
the recent inclusion of the latter as an environmental measure within the CEQA. To facilitate the equal distribution of knowledge to local jurisdictions of all densities and economies, the state of California should serve as the main resource for information regarding VMT and provide grants for local organizations and planners to contribute to the body of knowledge.

Developing robust VMT estimation and evaluation tools should be prioritized and deployed to local governments. The main concern of both smaller and larger jurisdictions is that current VMT estimation tools can be inaccurate or unreliable due to each project's unique characteristics, or the sensitivity of VMT impact analysis to model assumptions. Another important resource that is needed is a VMT evaluation tool that measures the effectiveness of potential mitigation strategies, which consider both project-level, street-scale factors, such as microscale aspects of urban design, but also regional-level factors such as land use and transportation patterns, in addition to considering equity indicators. This report sets the stage for developing such a tool, as it provides robust quantitative evidence that VMT can be reliability predicted when accounting for contributing factors at multiple scales. Without reliable and effective evaluation tools, local governments cannot establish transparency and accountability in reducing VMT.

Statewide VMT banks and exchanges can be effectively managed at the regional level with local input. The state can develop a statewide fund (similar to the cap-and-trade fund), where all revenues from the off-site VMT mitigation program are deposited. A statewide fund should guarantee that a certain percentage of investment benefits disadvantaged communities. A large statewide fund will also allow investments in larger transportation projects and programs across the state with a significant VMT reduction potential. The funds can then be appropriated to regional entities to invest in such transportation projects and programs. Issues surrounding high VMT areas often require regional solutions through transportation accessibility across jurisdictional lines. By administering off-site VMT mitigation under a regional authority, these strategies could avoid conflicts between cities and counties. Additionally, regional agencies are well-positioned to work with local governments and incorporate an equity lens to ensure the fair distribution of VMT mitigation benefits. 


\section{Limitations and Suggestions for Future Research}

This study was limited to a sample of counties located within northern and southern California only. Accordingly, it is possible that the relationships observed between VMT, sprawl, urban design, transit, and income may differ in other parts of California, such as the Central Valley, where other factors unique to counties within that area may impact the relationships observed in this study. Additionally, a sample of 60 counties is sufficient to create a statistically significant and robust model for VMT; however, given the finding of a significant four-way interaction (between micro and macroscale built environment features, transit access, and sprawl) and the fact that this led to the identification of 16 area types $(4 \times 4)$, the sample only accounted for a few areas of each type, and for some of the 16 types, there were no corresponding counties. This makes it difficultand in some cases impossible - to interpret the between-sample findings, comparing specific area types to others. As such, future sampling strategies should ensure distribution across all 16 types.

Additionally, given limitations in data availability, this study used a variety of data extracted at three geographical units of analysis (also known as nested data) - the street block, the census block group, and the census tract. While stepwise regression was used to ensure the validity of the linear regression model produced for this study, future research should implement multilevel modeling techniques to account for potential biases in the specification of the coefficients in the model.

Lastly, the qualitative findings are based on a relatively limited number of interviewees representing cities in northern and southern California. Future research could focus on the perspectives of experts representing other areas in the state, especially rural communities that may be working with a different set of opportunities and challenges related to off-site VMT mitigation. 


\section{Endnotes}

${ }^{1}$ Elisa Barbour and Daniel Chatman, "SB 743 implementation: Challenges and opportunities," California Department of Transportation, 2019.

${ }^{2}$ Ethan Elkind, Ted Lamm, and Eric Prather, "Implementing SB 743: An analysis of vehicle miles traveled banking and exchange frameworks," UC ITS, 2018.

${ }^{3}$ Barbour and Chatman, "SB 743 implementation: Challenges and opportunities."

${ }^{4}$ Barbour and Chatman, "SB 743 implementation: Challenges and opportunities."

${ }^{5}$ Mateus Humberto et al., "Walking and walkability: Do built environment measures correspond with pedestrian activity?" Ambiente Construido 19, no. 4 (2019): 31.

${ }^{6}$ Maria Johansson, Catharina Sternudd, and Mattias Kärrholm, "Perceived urban design qualities and affective experiences of walking," Journal of Urban Design 21, no. 2 (2016): 255.

${ }^{7} \mathrm{Li}$ Yin, "Street level urban design qualities for walkability: Combining 2D and 3D GIS measures," Computers, Environment and Urban Systems 64 (2017): 295.

${ }^{8}$ S. Hassan Ameli et al., "Do better urban design qualities lead to more walking in Salt Lake City, Utah?" Journal of Urban Design 20, no. 3 (2015): 405.

${ }^{9}$ Reid Ewing et al., "Streetscape features related to pedestrian activity," Journal of Planning Education and Research 36, no. 1 (2016): 12.

${ }^{10}$ Barbour and Chatman, "SB 743 implementation: Challenges and opportunities."

${ }^{11}$ Ewing et al., "Streetscape features related to pedestrian activity."

${ }^{12}$ Yong Yang, "Interactions between psychological and environmental characteristics and their impacts on walking," Journal of Transport E Health 2, no. 2 (2015): 197

${ }^{13}$ Mariela A. Alfonzo, "To walk or not to walk? The hierarchy of walking needs," Environment and Behavior 37, no. 6 (2005): 810.

${ }^{14}$ Lisabeth Rothman, "CEQA Turns Forty The More Things Change, The More They Remain The Same," UC Davis School of Law, accessed July 27, 2020, https://aw.ucdavis.edu/centers/environmental/conferences/2011/ceqa-materials.html.

${ }^{15}$ Ethan Elkind, Ted Lamm, and Eric Prather, "Implementing SB 743: An Analysis of Vehicle Miles Traveled Banking and Exchange Frameworks", University of California Center for Economic Competitiveness in Transportation, published June 2019, 1, doi:10.7922/G2S180Q7.

${ }^{16}$ Elkind, Lamm and Prather, "Implementing SB 743: An Analysis of Vehicle Miles Traveled Banking and Exchange Frameworks," 26.

17 "CEQA Portal Topic Paper Mitigation Measures," Association of Environmental Professionals, updated February 10, 2020, 1, https://ceqaportal.org/tp/CEQA\%20Mitigation\%202020.pdf

${ }^{18}$ Bruce McKenny, "Environmental Offset Policies, Principles, and Methods: A Review of Selected Legislative Frameworks," Biodiversity Neutral Initiative, published March 30, 2005, ii, https://www.foresttrends.org/publications/environmental-offset-policies-principles-and-methods-a-review-of-selected-legislativeframeworks-2/. 
${ }^{19}$ Todd BenDor and Audrey Stewart, "Land Use Planning and Social Equity in North Carolina's Compensatory Wetland and Stream Mitigation Programs," Environmental Management 47 (2011): 239, https://doi.org/10.1007/s00267-010-9594-z.

${ }^{20}$ Trace M. McKellips, "Spatial Patterns and Equity Implications of Wetland Mitigation in Western Washington," (master's thesis, Evergreen State College, 2017), 21, http://archives.evergreen.edu/masterstheses/Accession8610MES/McKellips_TMMESthesis2017.pdf.

${ }^{21}$ Palmer Hough and Morgan Robertson, "Mitigation under Section 404 of the Clean Water Act: where it comes from, what it means," Wetlands Ecology and Management 17 (2009): 25, https://doi.org/10.1007/s11273-0089093-7.

${ }^{22}$ Hough and Robertson, "Mitigation under Section 404 of the Clean Water Act: where it comes from, what it means."

${ }^{23}$ US Army Corps of Engineers and Environmental Protection Agency, "Wetlands Mitigation Final Rule," published April 10, 2008, https://www.epa.gov/sites/production/files/201503/documents/2008_04_10_wetlands_wetlands_mitigation_final_rule_4_10_08.pdf.

${ }^{24}$ Government of the United States. "Federal Guidance on the Use of Off-Site and Out-of-Kind Compensatory Mitigation Under Section 404 of the Clean Water Act.” Published May 6, 2009. https://www.foresttrends.org/publications/federal-guidance-on-the-use-of-off-site-and-out-of-kind-compensatory-mitigationunder-section-404-of-the-clean-water-act/

${ }^{25}$ Bruce McKenny, "Environmental Offset Policies, Principles, and Methods: A Review of Selected Legislative Frameworks," Biodiversity Neutral Initiative, published March 30, 2005, 18, https://www.foresttrends.org/publications/environmental-offset-policies-principles-and-methods-a-review-of-selected-legislativeframeworks-2/

${ }^{26}$ Douglas R Porter et al., Mitigation Banking (Washington: Island Press, 1996), 44.

${ }^{27}$ Porter, et al., Mitigation Banking, 80.

${ }^{28}$ Stephen Crooks and Laure Ledoux, "Mitigation banking: Potential applications in the UK," Centre for Social and Economic Research on the Global Environment, published January 2000, https:/www.researchgate.net/publication/292866030_Mitigation_banking_Potential_applications_in_the_UK

${ }^{29}$ Audrey Stewart, "Examining North Carolina's Compensatory Wetland Mitigation Program from the Perspectives of Land Use Planning and Social Equity," (master's thesis, University of North Carolina at Chapel Hill, 2009), 4, https://pdfs.semanticscholar.org/f8eb/a0a141c7bdcfee529e7d9a5d9eee4cb61589.pdf

${ }^{30}$ McKenny, "Environmental Offset Policies, Principles, and Methods: A Review of Selected Legislative Frameworks," 20.

${ }^{31}$ Amy Wilson Morris and Jessica Owley, "Mitigating the Impacts of the Renewable Energy Gold Rush," Minnesota Journal of Law no. 8 (2014): 330.

32 Morris and Owley, "Mitigating the Impacts of the Renewable Energy Gold Rush," 354.

${ }^{33}$ Fehr and Peers. "VMT Mitigation Through Fees, Banks, \& Exchanges." published April 2020, page 4-5. https://www.fehrandpeers.com/wp-content/uploads/2020/04/VMT-Fees_Exchanges_Banks-WhitePaper_Apr2020.pdf

${ }^{34}$ A. Dan Tarlock, "City versus Countryside: Environmental Equity in Context," Fordham Urban Law Journal 21, no. 3 (1994): 464, https://ir.lawnet.fordham.edu/ulj/vol21/iss3/3/ 
${ }^{35}$ Keone Kelobonye et al., "Measuring the accessibility and spatial equity of urban services under competition using the cumulative opportunities measure," Journal of Transport Geography 85 (2020): 1, https://doi.org/10.1016/j.jtrangeo.2020.102706

${ }^{36}$ Seth B. Shonkoff et al., "The climate gap: environmental health and equity implications of climate change and mitigation policies in California—a review of the literature," Climatic Change 109 (2011): S494, https://doi.org/10.1007/s10584-011-0310-7

${ }^{37}$ Trace M. McKellips, "Spatial patterns and equity implications of wetland mitigation in Western Washington," (master's thesis, Evergreen State College, 2017), 83, http://archives.evergreen.edu/masterstheses/Accession8610MES/McKellips_TMMESthesis2017.pdf

${ }^{38}$ McKellips, "Spatial patterns and equity implications of wetland mitigation in Western Washington," 94.

${ }^{39}$ Daniel L. Farber, "Pollution Markets and Social Equity: Analyzing the Fairness of Cap and Trade," Ecology law quarterly 39, no. 1 (2012): 34, https://www.researchgate.net/publication/286333016_Pollution_Markets_and_Social_Equity_Analyzing_the_ Fairness_of_Cap_and_Trade

${ }^{40}$ Thomas A. Williams, "Methodologies Used to Estimate and Forecast Vehicle Miles Traveled (VMT)," Texas A\&M Transportation Institute, published July 2016, https://static.tti.tamu.edu/tti.tamu.edu/documents/PRC2016-2.pdf

${ }^{41}$ Williams, "Methodologies Used to Estimate and Forecast Vehicle Miles Traveled (VMT)," 2.

${ }^{42}$ Amy E. Lee and Susan L. Handy, "Leaving level-of-service behind: The implications of a shift to VMT impact metrics," Research in Transportation Business \& Management 29, (2018): 16, https://doi.org/10.1016/j.rtbm.2018.02.003

${ }^{43}$ California Governor's Office of Planning and Research, "Preliminary Evaluation of Alternative Methods of Transportation Analysis," published December 30, 2013, 9, https://opr.ca.gov/docs/PreliminaryEvaluationTransportationMetrics.pdf

${ }^{44}$ Chase Stone, "Easements, Exchanges, and Equity: Models for California's Climate and Housing Crises," Hastings Environmental Law Journal 26, no. 2 (2020): 298, https://repository.uchastings.edu/hastings_environmental_law_journal/vol26/iss2/6/

${ }^{45}$ Stone, "Easements, Exchanges, and Equity: Models for California's Climate and Housing Crises."

${ }^{46}$ Smart Growth America, "The State of Transportation and Health Equity," published December 2019, 13, https://smartgrowthamerica.org/resources/the-state-of-transportation-and-health-equity/

${ }^{47}$ Aurobindo Ogra and Robert Ndebele, "The Role of 6Ds: Density, Diversity, Design, Destination, Distance, and Demand Management in Transit Oriented Development (TOD)," Conference Paper, published October 2014, https://www.researchgate.net/publication/268813431

${ }^{48}$ Smart Growth America, "The State of Transportation and Health Equity," 14.

${ }^{49}$ City of Oakland Department of Transportation, “Oakland Walks! 2017 Pedestrian Plan Update,” 13.

${ }^{50}$ Mark Buckley and Elizabeth Crone, "Negative Off-Site Impacts of Ecological Restoration: Understanding and Addressing the Conflict," Conservation Biology 22, no. 5 (October 2008): 1122, https://www.jstor.org/stable/20183506

${ }^{51}$ Smart Growth America, "The State of Transportation and Health Equity," 51-52.

${ }^{52}$ Amy Lee, Kevin Fang and Susan Handy, "Evaluation of Sketch-Level VMT Quantification Tools," National Center for Sustainable Transportation, draft published May 22, 2017, 
https://www.semanticscholar.org/paper/Evaluation-of-Sketch-Level-VMT-Quantification-A-LeeFang/e441a7a4bca176fa189c0bf692ec3e82d07534fe

${ }^{53}$ Elisa Barbour et al., "SB 743 Implementation: Challenges and opportunities," UC Berkeley: Institute of Transportation Studies at UC Berkeley, published June 1, 2019, https://escholarship.org/uc/item/4gj3n2n3

${ }^{54}$ Yi Zhang et al., "Does the Built Environment Make a Difference? An Investigation of Household Vehicle Use in Zhongshan Metropolitan Area, China," Sustainability 6, no. 8 (2014): 4926, https://doi.org/10.3390/su6084910

${ }^{55}$ Callista A. Ottoni et al., "Benches become like porches': Built and social environment influences on older adults' experiences of mobility and well-being," Social Science \& Medicine 169 (2016): 40, https://doi.org/10.1016/j.socscimed.2016.08.044

${ }^{56}$ Saehoon Kim, Sungjin Park and Jae Seung Lee, "Meso- or microscale? Environmental factors influencing pedestrian satisfaction," Transportation Research Part D: Transport and Environment 30 (2014): 18, https://doi.org/10.1016/j.trd.2014.05.005

${ }^{57}$ Gregory L. Newmark and Peter M. Haas, "Income, Location Efficiency, and VMT: Affordable Housing as a Climate Strategy," Center for Neighborhood Technology, published December 16, 2015, 5, https:/www.cnt.org/sites/default/files/publications/CNT\%20Working\%20Paper\%20revised\%202015-1218.pdf

${ }^{58}$ Reid Ewing and Shima Hamidi, "Measuring Urban Sprawl and Validation Sprawl Measures," Metropolitan Research Center, published January 2010, https://www.researchgate.net/publication/265164422_Measuring_Urban_Sprawl_and_Validating_Sprawl_Mea sures-Draft

${ }^{59}$ Christopher B. Leinberger and Mariela Alfonzo, Walk this way: The economic promise of walkable places in metropolitan Washington, DC (Washington, DC: Brookings Institution, 2012).

${ }^{60}$ Julia Koschinsky et al., "How walkable is Walker's paradise?" Environment and Planning B: Urban Analytics and City Science 44, no. 2 (2017): 343-363.

${ }^{61}$ City of San Diego, “San Diego’s Climate Equity Index Report 2019,” 8. 


\section{Appendices}

\section{Appendix A. Interview Protocol}

Interviewee:

Date:

Time:

Interviewer:

Overall impressions:

Getting started

Before I ask my first question, let me remind you what our study is about. Our goal is to help California ensure that off-site vehicle miles traveled (VMT) mitigation efforts tied to SB 743 are equitably and proportionately distributed. Specifically, we seek to assess and inform mechanisms that can objectively evaluate whether proposed off-site projects, either through banking or exchanges, would disproportionately increase VMT and/or inequitably refrain access to benefits tied to mitigation projects in disadvantaged communities.

Before we start, let me ask if you have any questions about the form I e-mailed for you. Was anything unclear?

Ok. I would like to record our interview today to be sure I accurately capture your thoughts. Is it ok for me to record the interview?

[If yes, start Zoom recording]

Please tell me briefly about your understanding of SB 743, and the ways it impacts your work?

How much do you know about off-site VMT mitigation practices? Have you implemented these in any form in the past?

How effective were off-site VMT mitigation techniques in your specific jurisdiction?

What are the biggest challenges involved with off-site VMT impact mitigation?

Here, I might ask more generally about challenges - and then if they don't mention equity, ask directly. I think it would be interesting to know if this is even a top of mind consideration.

COVID-19 and equity

What are the opportunities involved with off-site VMT impact mitigation?

What would local governments typically want developers to do to reduce the impact on VMT of their developments?

More funding for regional transportation 
Changes to the design of their development

What factors should be considered to ensure the equitable and proportionate distribution of transportation and urban design improvements tied to VMT mitigation?

Should microscale urban design features be considered?

Did you use VMT estimation tools in the past? How?

As follow ups, ask about challenges, lessons learned, gaps, etc.

How can the State of California help local and regional entities develop and implement off-site VMT mitigation programs?

Have you contacted or reached out to get help on implementing mitigation programs?

What transportation improvement efforts have been undertaken to address the needs of disadvantaged communities? Were they effective? Why or why not?

How can local, regional, and state level organizations cooperate to ensure the equitable distribution of transportation and built environment improvements tied to VMT mitigation?

Is there not enough/too much enforcement at the state level?

Are local governments overburdened without having resources? 
Appendix B.Glossary

\begin{tabular}{|c|c|}
\hline ANOVA & $\begin{array}{l}\text { a statistical model that analyzes the differences between means to determine } \\
\text { significance }\end{array}$ \\
\hline Cap-and-trade & $\begin{array}{l}\text { a market-based approach to emissions regulation, which involves the purchase of } \\
\text { allowances to emit pollutants }\end{array}$ \\
\hline CEQA & $\begin{array}{l}\text { the California Environmental Quality Act of 1970, the state-level environmental } \\
\text { protection statute }\end{array}$ \\
\hline CES & $\begin{array}{l}\text { CalEnviroScreen; an index released by the California Office of Environmental } \\
\text { Health Hazard Assessment to identify communities affected by pollution }\end{array}$ \\
\hline Density & number of people in a given area \\
\hline Equity & the element of fairness in receiving benefits and bearing the burdens of mitigation \\
\hline H+T Index & $\begin{array}{l}\text { the Housing and Transportation Affordability Index, developed by the Center for } \\
\text { Neighborhood Technology, provides a score for housing and transportation } \\
\text { burdens on a community }\end{array}$ \\
\hline $\begin{array}{l}\text { Intersection } \\
\text { Density }\end{array}$ & number of intersections in a given area \\
\hline Land Use Mix & number of unique land use types in a given area \\
\hline LOS & level-of-service, a measurement of vehicular traffic quality \\
\hline $\begin{array}{l}\text { Microscale } \\
\text { Features }\end{array}$ & street-level urban design features such as street trees, curb cuts, sidewalks, etc. \\
\hline Mitigation & an action, strategy, or policy to reduce a project's environmental impact \\
\hline Mitigation Bank & $\begin{array}{l}\text { a mitigation system where restoration efforts are converted to credits, which can } \\
\text { then be exchanged as currency }\end{array}$ \\
\hline $\begin{array}{l}\text { Mitigation } \\
\text { Exchange }\end{array}$ & $\begin{array}{l}\text { a mitigation system where developers choose a VMT reduction measure from a } \\
\text { predetermined list of choices to incorporate in their project scope }\end{array}$ \\
\hline $\begin{array}{l}\text { Off-site } \\
\text { Mitigation }\end{array}$ & a mitigation effort that occurs outside the boundaries of a project \\
\hline SB-535 & $\begin{array}{l}\text { Senate Bill 535, passed in 2012, directed a portion of cap-and-trade revenues to } \\
\text { disadvantaged communities, determined by their CalEnviroScreen (CES) score }\end{array}$ \\
\hline SB-743 & Senate Bill 743, passed in 2013, mandated the transition to VMT away from LOS \\
\hline SoP Index & $\begin{array}{l}\text { the State of Place Index collects and quantifies the quality of macroscale built } \\
\text { environment features in a community }\end{array}$ \\
\hline Sprawl & the unrestricted and irregular growth of urban development \\
\hline TDM & $\begin{array}{l}\text { transportation demand management; a combination of policy and interventions to } \\
\text { promote efficient transportation systems }\end{array}$ \\
\hline $\begin{array}{l}\text { Tukey HSB Post } \\
\text { Hoc Test }\end{array}$ & $\begin{array}{l}\text { the Tukey's Honest Significant Difference test compares all possible pairs of } \\
\text { means after data is collected }\end{array}$ \\
\hline VMT & vehicle-miles traveled; a measure of how many miles a person has driven \\
\hline
\end{tabular}




\section{Bibliography}

Alfonzo, Mariela A. "To walk or not to walk? The hierarchy of walking needs." Environment and Behavior 37, no. 6 (2005): 808-836.

Ameli, S. Hassan, Shima Hamidi, Andrea Garfinkel-Castro, and Reid Ewing. "Do better urban design qualities lead to more walking in Salt Lake City, Utah?" Journal of Urban Design 20, no. 3 (2015): 393-410.

Association of Environmental Professionals. "CEQA Portal Topic Paper Mitigation Measures." February 10, 2020. https://ceqaportal.org/tp/CEQA\%20Mitigation\%202020.pdf

Barbour, Elisa and Daniel Chatman. "SB 743 implementation: Challenges and opportunities." California Department of Transportation. 2019.

Barbour, Elisa, Daniel Chatman, Sarah Doggett, Stella Yip, and Manuel Santana. "SB 743 Implementation: Challenges and opportunities." UC Berkeley: Institute of Transportation Studies at UC Berkeley. June 1, 2019. https://escholarship.org/uc/item/4gj3n2n3

BenDor, Todd and Audrey Stewart. "Land Use Planning and Social Equity in North Carolina's Compensatory Wetland and Stream Mitigation Programs." Environmental Management 47 (2011): 239-253. https://doi.org/10.1007/s00267-010-9594-z

Buckley, Mark, and Elizabeth Crone. "Negative Off-Site Impacts of Ecological Restoration: Understanding and Addressing the Conflict," Conservation Biology 22, no. 5 (2008): 1181124. https://www.jstor.org/stable/20183506

California Governor's Office of Planning and Research. "Preliminary Evaluation of Alternative Methods of Transportation Analysis." December 30, 2013. https://opr.ca.gov/docs/PreliminaryEvaluationTransportationMetrics.pdf

City of Oakland Department of Transportation. "Oakland Walks! 2017 Pedestrian Plan Update." September 2018.

http://www2.oaklandnet.com/oakca1/groups/ceda/documents/report/oak067016.pdf

City of San Diego, “San Diego's Climate Equity Index Report 2019.” 2019.

https://www.sandiego.gov/sites/default/files/2019_climate_equity_index_report.pdf

Crooks, Stephen and Laure Ledoux. "Mitigation banking: Potential applications in the UK." Centre for Social and Economic Research on the Global Environment. January 2000. https://www.researchgate.net/publication/292866030_Mitigation_banking_Potential_applic ations_in_the_UK.

Cushing, Lara, Dan Blaustein-Rejto, Madeline Wander, Manuel Pastor, James Sadd, Allen Zhu, and Rachel Morello-Frosch. "Carbon trading, co-pollutants, and environmental equity: Evidence from California's cap-and-trade program (2011-2015)," PLoS Med 15, no. 7 (2018). https://doi.org/10.1371/journal.pmed.1002604 
Elkind, Ethan, Ted Lamm, and Eric Prather. "Implementing SB 743: An Analysis of Vehicle Miles Traveled Banking and Exchange Frameworks." University of California Center for Economic Competitiveness in Transportation. June 2019. doi:10.7922/G2S180Q7

Ewing, Reid, Amir Hajrasouliha, Kathryn Neckerman, Marnie Purciel-Hill, and William Greene. "Streetscape features related to pedestrian activity." Journal of Planning Education and Research 36, no. 1 (2016): 5-15.

Ewing, Reid and Shima Hamidi. "Measuring Urban Sprawl and Validation Sprawl Measures," Metropolitan Research Center. January 2010. https://www.researchgate.net/publication/265164422_Measuring_Urban_Sprawl_and_Valid ating_Sprawl_Measures-Draft

Farber, Daniel L. "Pollution Markets and Social Equity: Analyzing the Fairness of Cap and Trade," Ecology law quarterly 39, no. 1 (2012): 1-56.

https:/www.researchgate.net/publication/286333016_Pollution_Markets_and_Social_Equit y_Analyzing_the_Fairness_of_Cap_and_Trade

Hough, Palmer and Morgan Robertson. "Mitigation under Section 404 of the Clean Water Act: where it comes from, what it means." Wetlands Ecology and Management 17 (2009): 15-33. https://doi.org/10.1007/s11273-008-9093-7

Humberto, Mateus, Rodrigo Laboissière, Mariana Giannotti, Cláudio Marte, Daniel Cruz, and Henrique Primon. "Walking and walkability: Do built environment measures correspond with pedestrian activity?" Ambiente Construido 19, no. 4 (2019): 23-36.

Johansson, Maria, Catharina Sternudd, and Mattias Kärrholm. "Perceived urban design qualities and affective experiences of walking." Journal of Urban Design 21, no. 2 (2016): 256-275.

Kelobonye, Keone, Heng Zhou, Gary McCarney, and Jianhong Xia. "Measuring the accessibility and spatial equity of urban services under competition using the cumulative opportunities measure." Journal of Transport Geography 85 (2020).

https://doi.org/10.1016/j.jtrangeo.2020.102706

Kim, Saehoon, Sungjin Park, and Jae Seung Lee. "Meso- or microscale? Environmental factors influencing pedestrian satisfaction." Transportation Research Part D: Transport and Environment 30 (2014): 10-20. https://doi.org/10.1016/j.trd.2014.05.005

Koschinsky, Julia, Emily Talen, Mariela Alfonzo, and Sungduck Lee. "How walkable is Walker's paradise?" Environment and Planning B: Urban Analytics and City Science 44, no. 2 (2017): 343-363.

Lee, Amy E. and Susan L. Handy. "Leaving level-of-service behind: The implications of a shift to VMT impact metrics." Research in Transportation Business E Management 29, (2018): 1425. https://doi.org/10.1016/j.rtbm.2018.02.003

Lee, Amy, Kevin Fang, and Susan Handy. "Evaluation of Sketch-Level VMT Quantification Tools.” National Center for Sustainable Transportation. May 22, 2017. https:/www.semanticscholar.org/paper/Evaluation-of-Sketch-Level-VMT-QuantificationA-Lee-Fang/e441a7a4bca176fa189c0bf692ec3e82d07534fe 
Leinberger, Christopher B. and Mariela Alfonzo. Walk this way: The economic promise of walkable places in metropolitan Washington, DC. Washington, DC: Brookings Institution, 2012.

McKellips, Trace M. "Spatial Patterns and Equity Implications of Wetland Mitigation in Western Washington.” master's thesis, Evergreen State College, 2017.

http://archives.evergreen.edu/masterstheses/Accession8610MES/McKellips_TMMESthesis2017.pdf

McKenny, Bruce. "Environmental Offset Policies, Principles, and Methods: A Review of Selected Legislative Frameworks.” Biodiversity Neutral Initiative. March 30, 2005. https:/www.forest-trends.org/publications/environmental-offset-policies-principles-andmethods-a-review-of-selected-legislative-frameworks-2/

Morris, Amy Wilson and Jessica Owley. "Mitigating the Impacts of the Renewable Energy Gold Rush.” Minnesota Journal of Law no. 8 (2014): 293-388.

Newmark Gregory L. and Peter M. Haas. "Income, Location Efficiency, and VMT: Affordable Housing as a Climate Strategy." Center for Neighborhood Technology. December 16, 2015. https:/www.cnt.org/sites/default/files/publications/CNT\%20Working\%20Paper\%20revised \%202015-12-18.pdf

Ogra, Aurobindo, and Robert Ndebele. "The Role of 6Ds: Density, Diversity, Design, Destination, Distance, and Demand Management in Transit Oriented Development (TOD)," Paper presented at the Neo-International Conference on Habitable Environments, NICHE 2014. https://www.researchgate.net/publication/268813431

Ottoni, Callista A., Joanie Sims-Gould, Meghan Winters, Myrthe Heijnen, and Heather A. McKay. "Benches become like porches': Built and social environment influences on older adults' experiences of mobility and well-being." Social Science E Medicine 169 (November 2016): 33-41. https://doi.org/10.1016/j.socscimed.2016.08.044

Porter, Douglas R., John De Grove, Lindell L. Marsh, and Salvesen, David. Mitigation Banking. Washington: Island Press, 1996.

Rao, Narasimha D. "International and intranational equity in sharing climate change mitigation burdens." Int Environ Agreements 14, (2014): 129-146. https://doi.org/10.1007/s10784-0139212-7

Rothman, Lisabeth. "CEQA Turns Forty: The More Things Change, The More They Remain The Same.” UC Davis School of Law, July 27, 2020. https://aw.ucdavis.edu/centers/environmental/conferences/2011/ceqa-materials.html

Shonkoff, Seth B., Rachel Morello-Frosch, Manuel Pastor, and James Sadd. "The climate gap: environmental health and equity implications of climate change and mitigation policies in California-a review of the literature." Climatic Change 109 (2011): 485-503. https://doi.org/10.1007/s10584-011-0310-7

Smart Growth America. "The State of Transportation and Health Equity.” December 2019. https://smartgrowthamerica.org/resources/the-state-of-transportation-and-health-equity/ 
Stewart, Audrey. "Examining North Carolina's Compensatory Wetland Mitigation Program from the Perspectives of Land Use Planning and Social Equity." master's thesis, University of North Carolina at Chapel Hill, 2009.

https://pdfs.semanticscholar.org/f8eb/a0a141c7bdcfee529e7d9a5d9eee4cb61589.pdf

Stone, Chase. "Easements, Exchanges, and Equity: Models for California's Climate and Housing Crises." Hastings Environmental Law Journal 26, no. 2 (2020): 289-310. https://repository.uchastings.edu/hastings_environmental_law_journal/vol26/iss2/6/

Tarlock, A. Dan. "City versus Countryside: Environmental Equity in Context." Fordham Urban Law Journal 21, no. 3 (1994): 461-494. https://ir.lawnet.fordham.edu/ulj/vol21/iss3/3/

US Army Corps of Engineers \& Environmental Protection Agency. "Wetlands Mitigation Final Rule.” April 10, 2008. https://www.epa.gov/sites/production/files/201503/documents/2008_04_10_wetlands_wetlands_mitigation_final_rule_4_10_08.pdf

Williams, Thomas A., Byron Chigoy, Jeff Borowiec, and Brianne Glover. "Methodologies Used to Estimate and Forecast Vehicle Miles Traveled (VMT).” Texas A\&M Transportation Institute. July 2016. https://static.tti.tamu.edu/tti.tamu.edu/documents/PRC-2016-2.pdf

Yin, Li. "Street level urban design qualities for walkability: Combining 2D and 3D GIS measures." Computers, Environment and Urban Systems 64 (2017): 288-296.

Yong Yang. "Interactions between psychological and environmental characteristics and their impacts on walking." Journal of Transport Eซ Health 2, no. 2 (2015): 195-198.

Zhang, Yi, Wei Wu, Yuan Li, Qixing Liu, and Chaoyang Li. "Does the Built Environment Make a Difference? An Investigation of Household Vehicle Use in Zhongshan Metropolitan Area, China." Sustainability 6, no. 8 (August 2014): 4910-4930.

https://doi.org/10.3390/su6084910 


\section{About the Authors}

\section{Serena E. Alexander, PhD}

Serena Alexander is an Associate Professor of Urban and Regional Planning and Director of Urban Online at San José State University. Her research predominantly focuses on developing and implementing cutting-edge strategies to address climate change and climate justice. Examples of her recent work include harnessing the greenhouse gas emissions and mobility equity potential of autonomous vehicles and on-demand mobility, and harmonizing climate change mitigation and adaptation in transportation and land-use planning. Dr. Alexander has published several peerreviewed journal articles and technical reports and presented her research at national and international conferences. She is currently establishing the American Collegiate Schools of Planning (ACSP) and Association of European Schools of Planning (AESOP) collaboration platform focusing on climate justice and best practices of climate action planning. Before joining the SJSU faculty, Dr. Alexander conducted community economic development and environmental policy research at the Center for Economic Development and the Great Lakes Environmental Finance Center at Cleveland State University, where she also received her doctorate in Urban Studies (Specialization in Urban Policy and Development). She holds master's degrees in Urban and Regional Planning from California State Polytechnic University, Pomona, and Architecture from Azad University of Tehran.

\section{Mariela Alfonzo, PhD.}

Dr. Mariela Alfonzo is an internationally-renowned thought-leader and speaker, with 20+ years of experience on the nexus between urban design, behavior, value. She is the Founder and CEO of State of Place, an urban design predictive analytics platform that quantifies quality of place, walkability, and benefits tied to built environment improvements. In 2014, she was named one of Urban Land Institute's 40 under 40 best young land use professionals around the globe; is a New Cities Foundation Placemaking Fellow; and is a Research Professor at NYU Tandon's School of Engineering. She holds a $\mathrm{PhD}$ in urban planning from UC Irvine, as well as a Masters in Urban Planning, and a BA from University of Miami in psychology and architecture. In 2005, she published a groundbreaking conceptual model around "The Hierarchy of Walking Needs," and later co-created the first comprehensive, objective walkability audit tool - the Irvine Minnesota Inventory (IMI) widely used by research and practice. She later developed the State of Place algorithm to synthesize IMI data into a walkability score. In 2016, she launched the State of Place software platform, funded by the National Science Foundation. Since then, her team has helped over 30 citymakers use data to increase walkability and quantify its benefits.

\section{Kevin Lee}

Kevin Lee is a graduate student in the Urban and Regional Planning program at San Jose State University. He received his bachelor's degree in Environmental Science from the University of California, Irvine in 2015. His career goals involve integrating an environmentally sustainable perspective in urban areas and utilizing public green space to encourage community connections. Through his graduate program and its wonderful faculty and peers, Kevin has gained a passion for geospatial data analysis and equity planning that he hopes to continue to utilize in future opportunities. 


\author{
Founder, Honorable \\ Norman Mineta* \\ Secretary (ret.), \\ US Department of Transportation \\ Chair, \\ Will Kempton \\ Retired Transportation Executive \\ Vice Chair, \\ Jeff Morales \\ Managing Principal \\ InfraStrategies, LLC \\ Executive Director, \\ Karen Philbrick, $\mathrm{PhD}^{*}$ \\ Mineta Transportation Institute \\ San José State University \\ Winsome Bowen \\ Vice President, Project Development \\ Strategy \\ WSP \\ David Castagnetti \\ Co-Founder \\ Mehlman Castagnetti Rosen \& \\ Thomas \\ Maria Cino \\ Vice President, America \& U.S. \\ Government Relations \\ Hewlett-Packard Enterprise \\ Grace Crunican** \\ Owner \\ Crunican LLC \\ Donna DeMartino \\ Managing Director \\ Los Angeles-San Diego-San Luis \\ Obispo Rail Corridor Agency
}

\section{Directors}

Karen Philbrick, PhD

Executive Director

Hilary Nixon, PhD

Deputy Executive Director

Asha Weinstein Agrawal, PhD

Education Director

National Transportation Finance Center Director

Brian Michael Jenkins National Transportation Security Center Director
John Flaherty

Senior Fellow

Silicon Valley American Leadership

Forum

William Flynn *

President \& CEO

Amtrak

Rose Guilbault

Board Member

Peninsula Corridor Joint Power

Board

Ian Jefferies*

President \& CEO

Association of American Railroads

Diane Woodend Jones

Principal \& Chair of Board

Lea \& Elliott, Inc.

David S. Kim*

Secretary

California State Transportation

Agency (CALSTA)

Therese McMillan

Executive Director

Metropolitan Transportation

Commission (MTC)

Abbas Mohaddes

President \& COO

Econolite Group Inc.

Stephen Morrissey

Vice President - Regulatory and

Policy

United Airlines
Dan Moshavi, $\mathrm{PhD}^{*}$

Dean

Lucas College and GraduateSchool

of Business, San José State

University

Toks Omishakin*

Director

California Department of

Transportation (Caltrans)

Takayoshi Oshima

Chairman \& CEO

Allied Telesis, Inc.

Greg Regan

President

Transportation Trades Department, AFL-CIO

Paul Skoutelas*

President \& CEO

American Public Transportation

Association (APTA)

Kimberly Slaughter

CEO

Systra USA

Beverley Swaim-Staley

President

Union Station Redevelopment

Corporation

Jim Tymon*

Executive Director

American Association of State

Highway and Transportation

Officials (AASHTO)

$*$ Ex-Officio

** = Past Chair, Board of Trustees 